UNIVERSIDADE DE SÃO PAULO

INSTITUTO DE GEOCIÊNCIAS

\title{
INVESTIGAÇÃO PALEONTOLÓGICA DO EVENTO HIDROTERMAL DE ANHEMBI (SP) NA FORMAÇÃO TERESINA (GRUPO PASSA DOIS, PERMIANO, BACIA DO PARANÁ)
}

\author{
Paulo Fernandes Roberto
}

Orientador: Prof. Dr. Thomas Rich Fairchild

\section{DISSERTAÇÃO DE MESTRADO}

Programa de Pós-Graduação em Geoquímica e Geotectônica

São Paulo

2014 


\title{
UNIVERSIDADE DE SÃO PAULO INSTITUTO DE GEOCIÊNCIAS
}

\section{"INVESTIGAÇÃO PALEONTOLÓGICA DO EVENTO HIDROTERMAL DE ANHEMBI (SP) NA FORMAÇÃO TERESINA (GRUPO PASSA DOIS PERMIANO, BACIA DO PARANÁ"}

\author{
PAULO FERNANDES ROBERTO
}

Orientador: Prof. Dr. Thomas Rich Fairchild

DISSERTAÇÃO DE MESTRADO

COMISSÃO JULGADORA

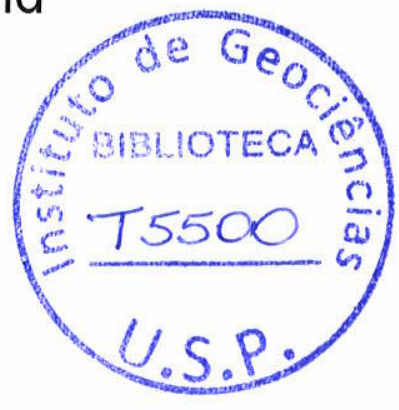

Assinatura

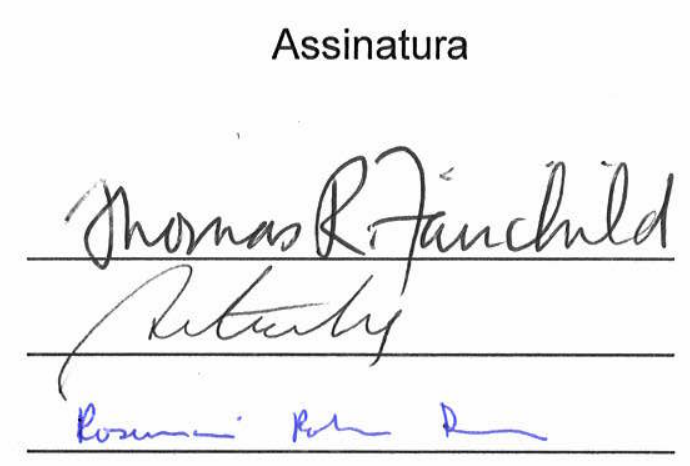

Presidente: Prof. Dr. Thomas Rich Fairchild

Titulares: $\quad$ Prof.. Dr. Setembrino Petri

Profa. Dra. Rosemarie Rohn Davies 


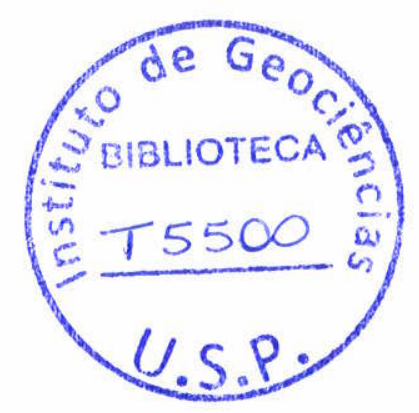

\section{INVESTIGAÇÃO PALEONTOLÓGICA DO EVENTO HIDROTERMAL DE ANHEMBI (SP) NA FORMAÇÃO TERESINA (GRUPO PASSA DOIS, PERMIANO, BACIA DO} PARANÁ)

Dissertação apresentada ao Instituto de Geociências da Universidade de São Paulo para obtenção do título de Mestre em Geociências

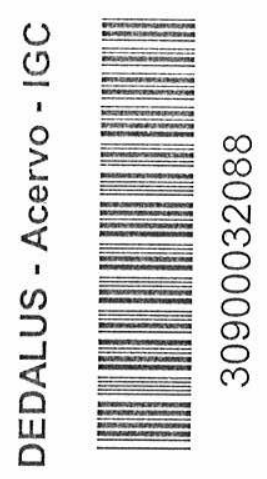

Programa de Pós- Graduação em Geotectônica e Geoquímica

Área de Concentração: Geotectônica

Orientador: Prof. Dr. Thomas Rich Fairchild

\section{São Paulo}


Nome: ROBERTO, P. F.

Título: Investigação Paleontológica do Evento Hidrotermal de Anhembi (SP) na Formação Teresina (Grupo Passa Dois, Permiano, Bacia do Paraná)

Dissertação apresentada ao Instituto de Geociências da Universidade de São Paulo para obtenção do título de Mestre em Geociências.

Aprovado Em:

\section{Banca Examinadora}

Prof. Dr. Instituição:

Julgamento: Assinatura:

Prof. Dr. Instituição:

Julgamento: Assinatura:

Prof. Dr. Instituição: Assinatura: 


\section{AGRADECIMENTOS}

Primeiramente gostaria de agradecer a meu orientador prof. Dr. Thomas Rich Fairchild pelo constante apoio, incentivo, paciência e ajuda essencial no decorrer do trabalho, além de possibilitar um grande sonho de criança.

Agradeço ao Programa de Pós-Graduação em Geoquímica e Geotectônica do Instituto de Geociências da Universidade de São Paulo e à CAPES pela oportunidade de poder desenvolver esta pesquisa com auxílio de bolsa.

Agradeço aos professores de disciplinas: prof. Dr. Paulo César Fonseca Gianinni, prof. Dr. Setembrino Petri, profa. Dra. Wânia Duleba e prof. Dr. Marcello Guimarães Simões pelo conhecimento adquirido no decorrer desses dois anos e por sempre mostrarem-se aptos a me ajudar.

Agradeço ao prof. Dr. Paulo César Boggiani e prof. Dr. Jorge Kazuo Yamamoto, por gentilmente cederem seus materiais e ajuda sempre que necessário.

Agradeço à profa. Dra. Juliana de Moraes Leme, ao prof. Dr. Luiz Eduardo Anelli e ao prof. Dr. Thomas Rich Fairchild por me permitirem atuar como monitor na disciplina de Paleontologia, a qual me ajudou a sempre revisar importantes conceitos paleontológicos, extremamente úteis para o desenvolvimento desse trabalho.

Agradeço aos colegas de pós-graduação por toda a gentileza e toda a ajuda prestada, sem a qual este trabalho não poderia ser realizado: Victor Cezar Soficier Badaró, Guilherme Raffaelli Romero, Cléber Pereira Calça, Luana Pereira Costa de Moraes Soares, Evelyn Aparecida Mecenero Sanchez Bizan; aos meus colegas Lucas Fernando Ferreira e Gabriel Ladeira Osés pelas observações geológicas tanto em campo como no laboratório.

Agradeço a todos os funcionários do IGc-USP que sempre com boa vontade me atenderam e mostraram-se muito prestativos.

Agradeço à minha namorada Marilice, por todo o amor, carinho e paciência que teve comigo no decorrer desses dois anos.

Finalmente agradeço aos meus pais, Rosa Maria e Fábio, e ao meu avô Flávio, pelo constante incentivo, orientação, amor e principalmente por terem acreditado em mim desde o começo (Ah, e pelos brinquedos de dinossauros ganhos quando criança!). 
"A sorte favorece os destemidos."

Alexandre, o Grande (356-323 a.C.) 


\section{RESUMO}

No município de Anhembi, ocorrem cones silicosos de dentro da Formação Teresina (Permiano) que, atualmente, são interpretados como acumulações geradas a partir de um evento hidrotermal em águas rasas. A ocorrência de depósitos hidrotermais é bastante rara no registro geológico, tornando o depósito de Anhembi único, ainda mais por apresentar mais de 4.500 dessas estruturas em pouco menos de $1,5 \mathrm{~km}^{2}$. As características marcantes desta localidade tornam-na um importante objeto de investigação científica, além de sugerirem a comparação com as supostamente mais antigas formas de vida encontradas de aproximadamente $3,5 \mathrm{Ga}$, em contexto similar. Este trabalho consiste numa análise dos fósseis encontrados em intervalos abaixo, lateralmente contínuos e acima da ocorrência desses cones, de uma avaliação de possíveis alterações da biota decorrentes desse evento hidrotermal e também de avaliar a controvérsia acerca dos supostamente mais antigos microfósseis da Terra. Foram analisados macroscopicamente e petrograficamente três intervalos distintos (A, B e C) em que foram coletadas amostras de três níveis diferentes (1, 2 e 3). No Intervalo A (Nível 1) foram observados conchas de bivalves, valvas de ostracodes, oncoides e fragmentos de dentes de peixes, inclusive com um fragmento grande de dente de peixe dipnoico. No Intervalo B (Nível 2) foram observados apenas valvas de ostracodes e oncoides. No Intervalo C (Nível 3) foram encontrados valvas de ostracodes, oncoides e conchas de bivalves. A silicificação dos intervalos A e B difere bastante da do Intervalo C, o que sugere um evento diferente para a silicificação nesses pontos. A aparente diferença encontrada nas biotas dos três intervalos sugere fortemente uma ligação da biota com o evento hidrotermal que ocorreu na região. A presença de microfósseis há 3,5 Ga não é descartada por esse trabalho, entretanto há de se ficar atento com as ressalvas feitas à biogenicidade desses microfósseis.

Palavras-chave: hidrotermalismo; fósseis; silicificação; Permiano; Formação Teresina 


\begin{abstract}
ABSTRAC"I
In the Anhembi County, siliceous cones occur in the Teresina Formation (Permian) which are now interpreted as accumulations generated from a hydrothermal event that took place in shallow waters. The occurrence of such hydrothermal deposits is very rare in the geological record, making this deposit unique, especially when considering that more than 4,500 of these siliceous cones outcrop in less than $1,5 \mathrm{~km}^{2}$. The remarkable characteristics of this locality have made it an important object of scientific investigation, aside from suggest the comparison with the supposedly most ancient life forms ever found, from $3.5 \mathrm{Ga}$, deposited in similar context. This work consists of an analysis of the fossils found in intervals below, laterally continuous and above the place where such cones outcrop, an evaluation whether possible changes in the biota in this area are due to this hydrothermal event, and also to perform an analysis of the state of the controversy around Earth's most ancient microfossils. Three different intervals (A, B and C) in which samples from three distinct levels (1,2 and 3) were collected were analyzed both macroscopically and petrographically. In the Interval A (Level 1) we have observed bivalve shells, ostracod valves, oncoids and fragments of fish teeth including a big fragmented tooth of a dipnoi fish. In Interval B (Level 2) were observed only ostracod valves and oncoids. In Interval C (Level 3) were found ostracod valves, oncoids and bivalve shells. The silicification that took place in these 2 initial intervals differ from the third one, which suggests a different event for the silicification of the lower strata. The apparent difference found in the biota from the three intervals strongly suggests a connection of the biota with the hydrothermal event that took place in that locality. The presence of $3.5 \mathrm{Ga}$ microfossils is not entirely discarded by this work, though one must be caution about the reservations about the biogenicity of such microfossils.
\end{abstract}

Keywords: hydrothermalism; fossils; silicification; Permian; Teresina Formation 


\section{SUIVARIU}

1 INTRODUÇÃO___ 8

2 CONTEXTO GEOLOGICO__ 10

2.1 Contexto Geológico da Bacia do Paraná ___ 10

2.2 Contexto Geológico do Grupo Passa Do1s___ 13

2.3 Contexto Geológico da Formação Teresina___ 14

2.4 Geologia da Area de Estudo___ 19

3 O EVENTO HIDROTERMAL DE ANHEMBI (SP)___ 21

4 MATERIAIS E METODOS _ 26

4.1 Trabalho de Campo__ 26

4.2 Análises Laboratoriais___ 30

5 RESULTADOS 32

5.1 Intervalo A e Nível 1__ 33

5.2 Intervalo B e Nível 2

5.3 Intervalo C e Nível 3

6 DISCUSSÃO__ 55

7 CONCLUSÖES___ 64

8 REFERÊNCIAS BIBLIOGRÁFICAS__ 65 


\section{INTRODUÇÃO}

No município de Anhembi, no interior do estado de São Paulo, ocorrem cones silicosos de dimensões métricas dentro da Formação Teresina, de idade Eopermiana, cuja gênese foi por muito tempo motivo de debates. Atualmente, são interpretados como acumulações geradas a partir de um evento hidrotermal em águas rasas (Yamamoto et al., 2005).

A ocorrência de depósitos hidrotermais é bastante rara no registro geológico. Entretanto, próximo a Anhembi (SP), existem mais de 4.500 desses corpos, concentrados em uma área de apenas $1,5 \mathrm{~km}^{2}$.

Inicialmente foram descritos como possíveis estromatólitos, mas diversas características remetem ao ambiente hidrotermal, como a ausência de evidências de composição calcária e de laminação microbiana. Também foi especulada por Yamamoto et al. (2005) a possibilidade de tais estruturas serem de fato ninhos de insetos, entretanto suas características remetem a ambientes sedimentares formados em sucessões de águas rasas, o que descartaria essa hipótese. Outra alternativa proposta foi que essas estruturas seriam, de fato, domos de sal. Ela, porém, foi rapidamente refutada em virtude da ausência de minerais evaporíticos nos corpos silicosos (Yamamoto et al, 2005).

Outro aspecto intrigante é relativo à formação desses cones, que implica, forçosamente, na presença de água, sílica, um sistema de encanamento e uma fonte de calor. A água e a fonte de sílica claramente estavam disponíveis pelas características das rochas sedimentares encontradas na Formação Teresina. Pouca evidência, porém, foi encontrada de um sistema de condutos, embora seja possível que a zona de silicificação abaixo de alguns dos corpos esteja relacionada a tais condutos. A ausência de vulcanismo no ambiente intraplaca da Bacia do Paraná no período Permiano apresenta o maior problema para explicar qual a fonte de calor do local, contudo, baseado em todas as outras evidências, pode-se dizer que um modelo hidrotermal seja o mais adequado no caso (Yamamoto et al, 2005).

Yamamoto et al. (2005) reconheceram microfósseis microbianos silicificados em níveis logo abaixo dos corpos silicosos, mas não apresentaram imagens nem detalhes sobre o modo de ocorrência e morfologia destes microfósseis.

As características marcantes desta localidade tornam-na um importante objeto de investigação científica, além de sugerirem a comparação com as supostamente mais antigas formas de vida encontradas de aproximadamente 3,5 bilhões de anos $(\mathrm{Ga})$, presentes na Austrália Ocidental, em região cujo depósito também é supostamente hidrotermal (Schopf, 1993, 2006; Schopf et al. (2002); Brasier et al., 2002). Sobre esta interpretação há certa 
controvérsia. Enquanto Schopf (1993) relata que os filamentos encontrados na região dentro de grãos silexíticos são de fato de origem bacteriana, Brasier et al. (2002) contestam interpretações ambientais levantadas por Schopf (1993) anteriormente, além de evidências sobre a origem biológica dos filamentos encontrados, classificando-os como artefatos abióticos.

Independentemente do debate acerca desse tema, o que há de comum entre o depósito descrito por Schopf (1993) e o trabalho por Yamamoto et al. (2005) é de que a sílica encontrada é primária e em ambos os casos foram encontrados microfósseis filamentosos, no caso de Yamamoto et al. (2005) não associados, diretamente, aos cones.

O presente trabalho, portanto, tem como objetivos:

1 a identificação de microfósseis e eventuais macrofósseis presentes em estratos lateralmente contínuos aos cones silicosos, e nos níveis estratigraficamente logo abaixo e logo acima deles; $\mathbf{2}$ a comparação dos microfósseis microbianos encontrados com formas que habitam regiões atuais similares em estrutura e composição e, finalmente;

3 com base nos resultados obtidos nesta pesquisa, avaliar a controvérsia entre (1993) e Brasier et al. (2002) acerca da natureza dos supostos microfósseis mais antigos preservados em sílex hidrotermal com mais de 3,5 bilhões de anos $(\mathrm{Ga})$. 


\section{CONTEXTO GEOLÓGICO}

\subsection{Contexto Geológico da Bacia do Paraná}

A Bacia do Paraná é uma das sinéclises brasileiras, ativas entre meados do Ordoviciano tardio até o final do Cretáceo (figura 2.1). Com forma aproximadamente elíptica, tendo seu eixo maior no sentido norte-sul, esta bacia sedimentar intracratônica recobre 1,5 milhões de $\mathrm{km}^{2}$ na porção sudoeste da América do Sul. Seu registro litológico alcança 6.000 metros de espessura com idades desde o Neo-Ordoviciano até o Neocretáceo. Este registro, entretanto, é descontínuo e dividido em supersequências (explicadas abaixo), com grande parte do intervalo abarcado (Pereira et al., 2012) representado por lacunas intraestratais e hiatos intrassequenciais.

Almeida (1980) e Zalán et al. (1990) denotam que o pacote de rochas sedimentares e vulcânicas da Bacia do Paraná representa superposição de pelo menos três bacias diferentes, individualizadas temporalmente, com suas respectivas geometrias variando no tempo em função do movimento das placas relacionadas à evolução de Gondwana. Nesta interpretação, a primeira bacia representaria as sequências ordoviciana, siluriana e devoniana, depositadas em um golfo com abertura para o paleo-Oceano Pacífico; a segunda, corresponderia à sequência permocarbonífera, originada num mar interior; enquanto a terceira fase seria a de erupção de lavas. Hoje em dia, há também um reconhecimento de uma "quarta bacia" do Paraná, a qual é estabelecida após os derrames vulcânicos ocorridos ao final da terceira bacia, chamada de Bacia Bauru (Pereira et al., 2012). 


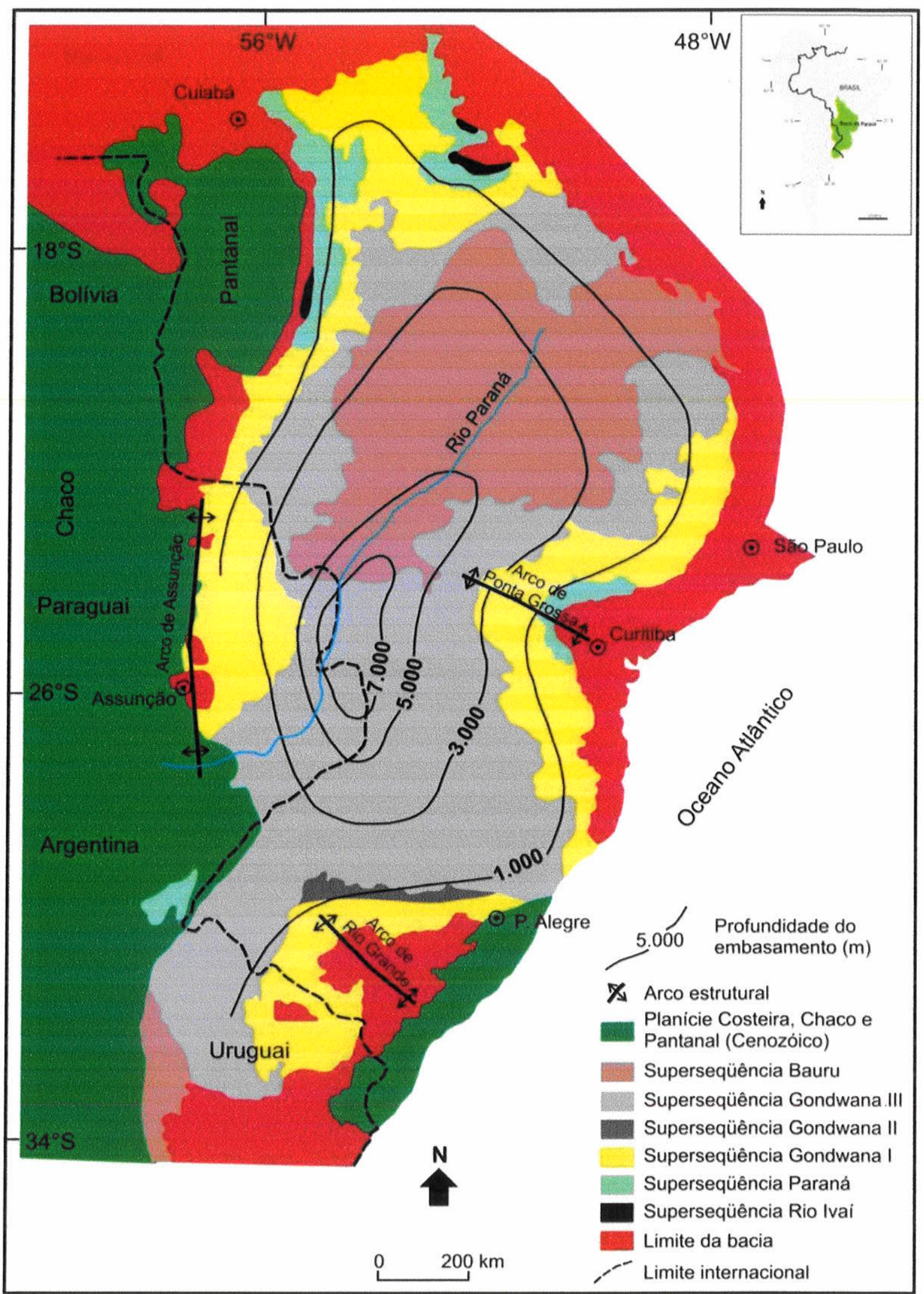

Figura 2.1: Mapa simplificado da Bacia do Paraná ilustrando a distribuição das principais supersequências e os limites da bacia. Modificado de Milani (1997). 
O trabalho pioneiro sobre a estratigrafia da Bacia do Paraná foi de White (1908), que estabeleceu a primeira coluna estratigráfica da bacia. As unidades litoestratigráficas criadas por ele serviram de base para todas as reavaliações feitas desde então. Segundo a divisão estratigráfica regional proposta por Milani (1997), dentro da bacia, existem seis ciclos de deposição de mais alta escala, constituídos de pacotes de rocha -- supersequências -- com várias centenas de metros de espessura cada uma. Elas são delimitadas por discordâncias formadas durante intervalos em que a bacia esteve submetida à ação erosiva em grande escala. As supersequências são: Rio Ivaí (Ordoviciano - Siluriano), Paraná (Devoniano), Gondwana I (Carbonífero - Eotriássico), Gondwana II (Meso a Neotriássico), Gondwana III (Neojurássico - Eocretáceo) e Bauru (Neocretáceo). As três primeiras sequências correspondem a grandes ciclos transgressivos paleozoicos e as demais são representadas por pacotes de sedimentos continentais, eventualmente com rochas ígneas associadas, cada qual com sua evolução condicionada por diferentes contextos tectônicos e paleoclimáticos.

A grande discordância erosiva entre as supersequências Paraná e Gondwana I envolveu um hiato estratigráfico de 40 milhões de anos (Ma), devido ao amplo soerguimento da bacia no Eocarbonífero, um provável reflexo dos movimentos tectônicos da Orogenia Eoherciniana (Zalán et al.,1991).

Segundo Pereira et al. (2012), o registro estratigráfico da Supersequência Gondwana I se trata do pacote com maior volume dentre as supersequências da Bacia do Paraná. Sua espessura máxima é de 2.500 metros, e os seus depósitos sedimentares são bastante heterogêneos, registrando variações paleoambientais contrastantes, desde fases glaciais do Carbonífero até fases áridas durante o Triássico. Litoestratigraficamente, o registro dessa supersequência é representado pelos Grupos Itararé, Guatá e Passa Dois, os quais se depositaram sob taxas relativamente altas de subsidência e deslocamento dos seus centros de deposição.

No Grupo Itararé ocorrem depósitos glaciogênicos, enquanto que no Grupo Guatá há depósitos de contexto deltaico, marinho e litorâneo. O Grupo Passa Dois mostra tendência ao raseamento, dando prosseguimento ao processo de continentalização da Bacia do Paraná (Pereira et al., 2012). 


\subsection{Contexto Geológico do Grupo Passa Dois}

O Grupo Passa Dois se estende desde o Eopermiano até muito provavelmente o Triássico inicial e é constituído, a partir da base, pelas formações Irati, Serra Alta, Teresina e Rio do Rasto (figura 2.2).

A Formação Irati apresenta faciologia variada, a qual inclui folhelhos, folhelhos betuminosos, arenitos, margas, carbonato e anidrita, e sua geometria de bacia implica em golfos e baías de profundidades e salinidades variáveis. A Formação Serra Alta apresenta estratos de folhelhos que registram um ciclo regressivo de ampla magnitude. A Formação Teresina consiste basicamente em argilitos e siltitos cinza-claros ou avermelhados, intercalados por calcários oolíticos e coquinas, sendo que sua deposição deve ter ocorrido em ambiente aquático raso com influência de ondas e marés. Finalmente, a Formação Rio do Rasto é composta por arenitos, siltitos e folhelhos arroxeados, esverdeados e avermelhados, aos quais pode-se atribuir uma deposição em sistema deltaico que avançou sobre a bacia desde sua borda oeste (Milani et al.,1994).

Durante a deposição do Grupo Passa Dois, observa-se uma tendência ao raseamento, finalmente culminando em um ambiente de deposição flúvio-deltaico inferido a partir do Membro Morro Pelado da Formação Rio do Rasto.

Alguns comentários sobre os fósseis presentes no Grupo Passa Dois ocorrem em Rohn (1994) e Meglhioratti (2006), sendo que os encontrados para essa unidade são, principalmente, bivalves, conchostráceos, microbialitos (estromatólitos, oncoides), gastrópodes, ostracodes, restos de peixes e vegetais. $\mathrm{O}$ que se nota nos fósseis encontrados é a tendência à continentalização da bacia.

De maneira geral, o Grupo Passa Dois é composto por diversos ciclos granocrescentes ascendentes, os quais denotam a tendência ao raseamento presente nessa unidade. Ocorrências carbonáticas em alguns intervalos (notadamente a Formação Teresina) correspondem a momentos de maior salinidade dentro da unidade, o que indica influência de ambientes áridos, enquanto os intervalos siliciclásticos correspondem a períodos de maior aporte de água, refletindo, então, o clima mais úmido (Meglhioratti, 2006). 


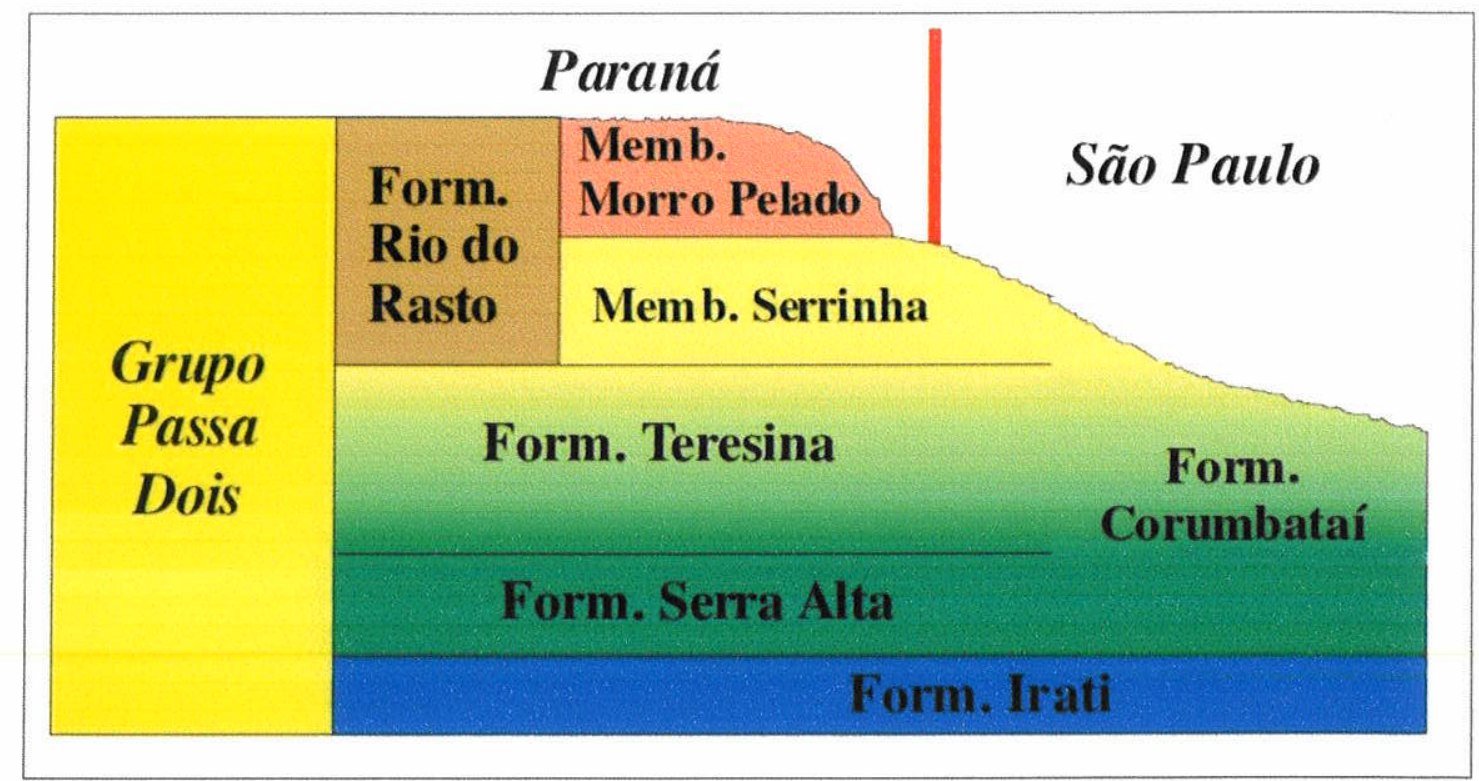

Figura 2.2: Litoestratigrafia do Grupo Passa Dois, abrangendo os estados do Paraná e São Paulo Retirado de Meglhioratti (2006).

\subsection{Contexto Geológico da Formação Teresina}

Existem algumas variações de nomenclatura para o intervalo estratigráfico correspondente à Formação Teresina, a unidade de maior interesse nesta dissertação. Na região norte-nordeste da bacia, o intervalo equivalente às formações Serra Alta e Teresina é normalmente designado Formação Corumbataí (Schneider et al., 1974). Nesta região os siltitos tornam-se avermelhados, em contrapartida com a coloração acinzentada mais comum ao restante da formação, a espessura total da unidade decresce, a proporção de arenitos, coquinas e bone-beds aparentemente aumenta e as rochas carbonáticas sofrem redução gradual em espessura. Contudo, apesar das diferenças observadas, Holz et al. (2010) observam não haver razões muito claras para o uso de nomes estratigráficos distintos para o uso do termo Formação Corumbataí. As unidades Teresina e Serra Alta, incluindo os estratos inferiores da Formação Rio do Rasto foram designadas como Formação Estrada Nova por Vieira (1973) para o estado de São Paulo e o termo foi posteriormente utilizado por alguns autores (Maranhão e Petri,1997), porém caiu em desuso e não é mais utilizado.

A Formação Teresina é inserida entre os andares Kunguriano e Roadiano. Santos et al. (2006) realizaram a datação radiométrica de U-Pb em grãos de zircão encontrados em cinzas vulcânicas da Formação Irati presentes em mina da Petrobrás, em São Mateus do Sul (PR). Os autores obtiveram idade aproximada de 278,4 $\pm 2,2$ Ma para a formação, o que seria próximo do limite Artinksiano-Kunguriano (Gradstein et al., 2012). Este fato prova-se coerente com os 
dados paleontológicos apresentados por Rohn e Stollhofen (2000), em que correlacionam unidades permianas da Bacia do Paraná com a Bacia de Karoo na África.

Rohn (1994) estabelece diferentes zoneamentos bioestratigráficos dentro da Formação Teresina, baseados em bivalves e megafósseis vegetais. $\mathrm{O}$ intervalo correspondente a essa unidade é inserido na zona Pinzonella neotropica quando levados em conta os bivalves e na zona Lycopodiopsis derbyi quando levados em conta os vegetais. Em Neregato et al. (2008) os autores compilam dados presentes em Daemon e Quadros (1970); Souza e Marques-Toigo (2005) e Souza (2006) sobre a bioestratigrafia da formação baseados em dados palinomórficos (figuras 2.3 e 2.4).

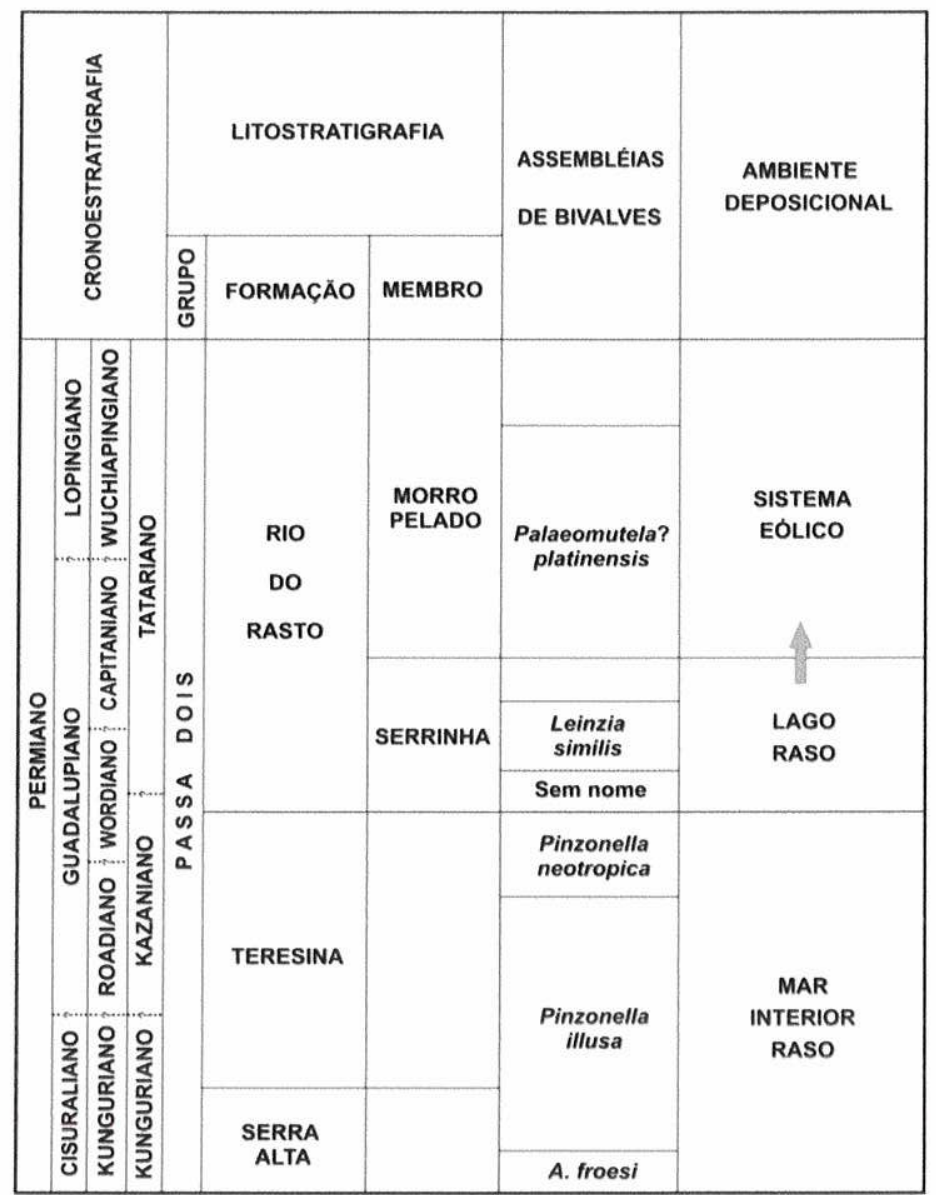

Figura 2.3: Bioestratigrafia do Grupo Passa Dois baseada em assembleias de bivalves. Notar que a Formação Teresina está temporalmente alocada entre as biozonas Pinzonella neotropica e Pinzonella illusa. Modificado de Simões et al. (2010). 


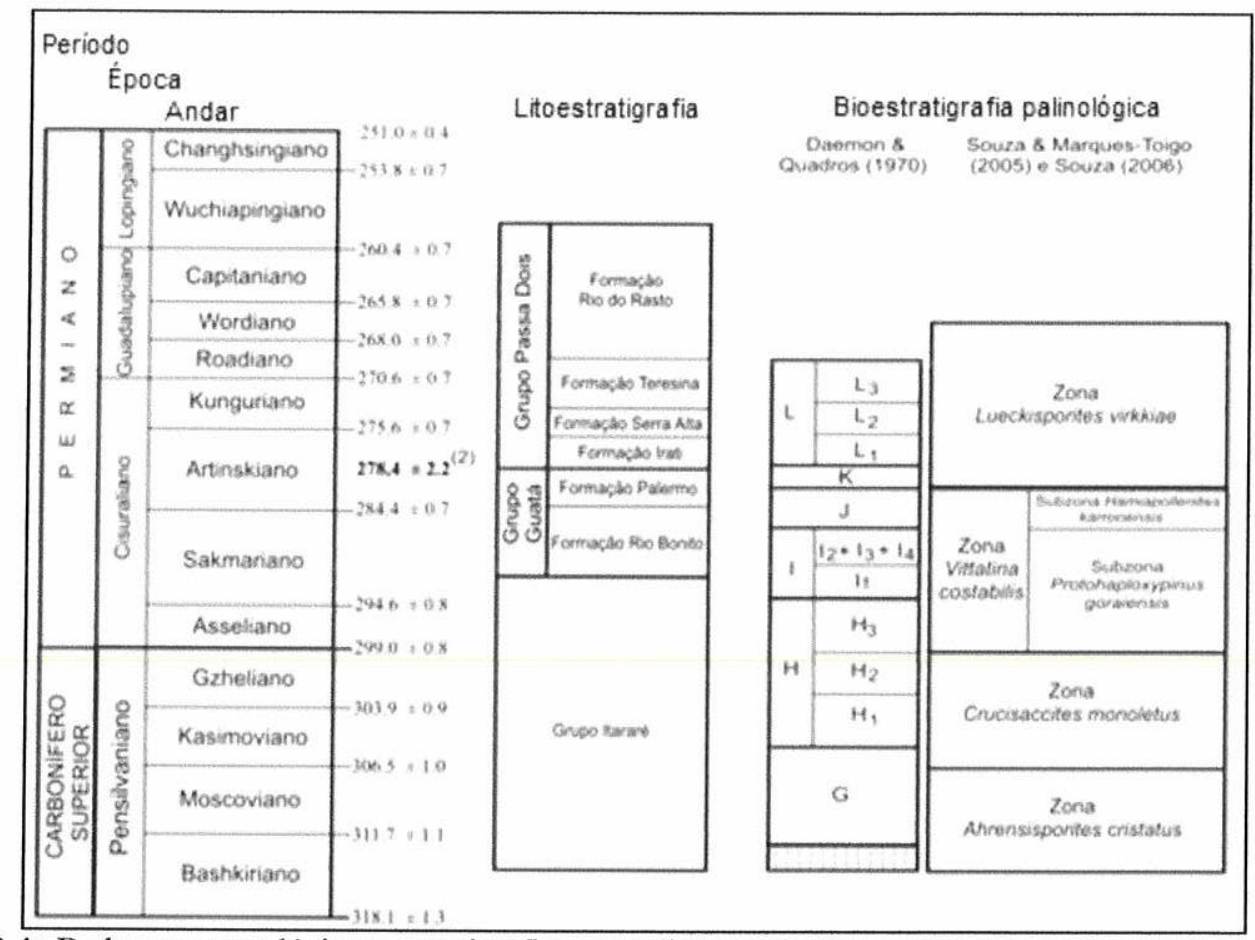

Figura 2.4: Dados geocronológicos, estratigráficos e palinoestratigráficos dos grupos Itararé, Guatá e Passa Dois. A Formação Teresina está temporalmente situada entre o Kunguriano e o Roadiano e faz parte da biozona Lueckisporites virkkiae. Modificado de Neregato et al. (2008). Notar que o esquema utiliza limites de idades para os estágios baseados em Gradstein et al. (2004).

A Formação Teresina já foi descrita como uma sucessão monótona com predomínio de siltitos intercalados por arenitos e calcários (Rohn, 2001). Essa unidade pode ter de 280 a 330 metros de espessura e apresenta ampla gama de estruturas sedimentares tais como acamamentos linsen, flaser e wavy, além de estratificações cruzadas hummocky e ocasionais gretas de contração. Frequentemente intercaladas com sucessões siliciclásticas, ocorrem rochas carbonáticas centimétricas e decimétricas (em sua maioria mudstones, algumas vezes com gretas de contração e intervalos brechados, grainstones oolíticos e boundstone microbianos), assim como coquinas de bivalves e bone-beds de restos de peixes (Holz et al., 2010).

Os sistemas deposicionais da Formação Teresina são alvo de diferentes interpretações. No passado, essa unidade foi interpretada como um sistema marinho raso e, em parte, associado a amplas áreas costeiras e planícies de maré (Sousa et al., 1991). Entretanto, o registro não evidencia uma conexão clara entre o mar epicontinental da Bacia do Paraná e o Oceano Panthalassa (Rohn, 1999 apud Rohn, 2001). A baixa diversidade dos fósseis e a ausência de táxons exclusivamente marinhos na formação também são evidências contra um ambiente marinho normal. Por tais características, um termo utilizado para descrever a Formação Teresina, sem diretamente implicar sua afinidade marinha, mas reconhecendo sua 
influência em determinadas partes da unidade é o "lago-mar" (Rohn, 1994). Segundo Holz et al. (2010), este se trata de um sistema deposicional tanto de ambientes offshore influenciados por tempestades, como de ambientes de planície de maré, com pouca contribuição carbonática se comparada à sedimentação siliciclástica. Com base em evidências sedimentológicas e paleontológicas, a paleossalinidade do ambiente deposicional da Formação Teresina parece ter variado entre um extremo - água doce - a outro - hipersalinidade (Meglhioratti, 2006). As rochas carbonáticas podem corresponder a fases de alta salinidade da água durante intervalos de clima seco, enquanto os intervalos representados por rochas siliciclásticas demonstram condições climáticas mais úmidas e águas mais salobras (Meglhioratti, 2006). A distribuição de grainstones oolíticos durante determinados intervalos indica que essas estruturas não se formaram apenas próximas da costa, mas também em porções mais centrais da bacia. As gretas de contração, quando presentes, também demonstram a mesma distribuição geográfica. Tais observações indicam que condições de águas rasas predominaram na bacia com ocasional exposição de áreas amplas (Holz et al., 2010), em função do assoalho muito plano da bacia (Meglhioratti, 2006).

Rohn (2001) apresentou detalhes das fácies da Formação Teresina ao longo de uma seção de $170 \mathrm{~m}$ registrados no furo de sondagem FP-12-SP da CPRM $(7.480 .600 \mathrm{mN}$ / $780.500 \mathrm{mE}$ ) em Botucatu.

A maior parte dessa unidade nesta área é constituída não por siltitos, mas por rochas heterolíticas caracterizadas por interlaminações de arenitos muito finos e folhelhos avermelhados e estruturas sedimentares com acamamento wavy, linsen e flaser com diferentes graus de bioturbação. Nos arenitos, notam-se laminações cruzadas feitas por ondas. Nas partes mais superiores da formação são frequentes as gretas de contração, que ocorrem predominantemente em folhelhos que constituem os flasers das rochas heterolíticas mais arenosas. Estratos areníticos espessos são pouco abundantes na Formação Teresina, todavia há um intervalo arenoso maior próximo à base da unidade, de aproximadamente 10 metros de espessura, caracterizado por arenitos muito finos com laminações cruzadas por ondas, laminação flaser e laminação cruzadas hummocky todos indicativos de deposição relacionada à tempestades (Meglhioratti, 2006). Os folhelhos escuros também são pouco abundantes na formação e geralmente possuem poucos centímetros de espessura. Ocorrem comumente entre camadas de carbonatos.

As rochas carbonáticas não são comuns dentro da unidade, porém sua frequência é maior na parte superior da formação. Usualmente estão intercalados com rochas siliciclásticas. Normalmente possuem espessura centimétrica a decimétrica e apresentam 
grande quantidade de bivalves fósseis. Os grainstones oolíticos ocorrem mais abundantemente na parte superior da unidade. Os ooides requerem águas agitadas, limpas e alcalinas para sua formação (Flügel, 2004) e podem ser formados tanto em ambientes marinhos rasos, com agitação periódica ou em ambientes lacustres, preferencialmente em ambientes de clima árido (Milroy e Wright, 2002). Rudstones são mais raros na região, apresentando em sua composição conchas e prováveis oncoides. Às vezes apresentam granodecrescência ascendente dos clastos, outras vezes evidenciando longo retrabalhamento, provavelmente por ondas, podendo corresponder a lags transgressivos (Rohn, 2001).

Ostracodes são relativamente frequentes em micritos da Formação Teresina. Sohn e Rocha-Campos (1990) consideram-nos de ambientes de água doce, mas por outro lado, Almeida e Do Carmo (2005) afirmaram, em um resumo, que alguns deles, na região norte da bacia, teriam sido marinhos e cosmopolitas, mas ainda não justificaram essa conclusão surpreendente em publicação completa. De acordo com Holz et al. (2010), outros microfósseis "marinhos" já foram reconhecidos, como raros foraminíferos, espículas de esponjas e até mesmo conodontes, mas até o momento estas ocorrências tampouco foram comprovadas em publicações.

$\mathrm{Na}$ Formação Teresina também se encontram diferentes espécies de moluscos bivalves, o tipo de fóssil mais comum dentro dessa unidade. Rohn (1994) assinala que as espécies da formação são encontradas com abundância, mas reconhece que em muitos casos elas se apresentam em calcários compactados ou silicificados, o que dificulta a preparação e subsequente análise do material.

Escamas de peixes, dentes e placas dentárias, juntamente com outros restos fósseis, ocorrem em bone-beds ou espalhados por várias litologias. Dentes de anfíbios também ocorrem nesses depósitos, embora sejam mais raros. Alguns desses restos de vertebrados indicam ambientes de água doce, como os anfíbios, mas podem ter sido transportados para ambientes deposicionais mais salinos, indicando mistura espacial (Toledo, 2001).

Microbialitos foram reconhecidos em diferentes pontos dentro da unidade, como no furo de sondagem FP-12-SP e no quilômetro 168 da Rodovia Castello Branco (Badaró, 2013), onde ocorrem intercalados com sucessões siliciclásticas. Como ocorrem em intervalos carbonáticos, eles aparentemente correspondem ao momento dentro da sucessão onde a costa foi afogada, assim a água era suficientemente limpa e permitia seu desenvolvimento. Apesar da subida do nível de base, o paleoambiente para esse local deve ser considerado relativamente raso, pois as cianobactérias formadoras dos microbialitos necessitam de luz 
para o seu desenvolvimento e o padrão colunar e oncolítico desses depósitos sugere energia relativamente alta do ambiente (Rohn, 2001).

Estão presentes em diferentes níveis estratigráficos da Formação Teresina no estado de São Paulo finos estratos constituídos, em grande parte, por folhas de licófitas retrabalhadas e concentradas em finos horizontes por ondas de tempestade. Elas foram permineralizadas por sílica durante a diagênese e por isso foram preservadas tridimensionalmente e até com conservação de detalhes celulares (Rohn, 2001). As folhas da licófita Lycopodiopsis derbyi são especialmente importantes pois essa espécie é utilizada como fóssil-guia da Formação Teresina (Roinn, 1Yy4).

\subsection{Geologia da Área de Estudo}

O presente trabalho foi realizado no Alto Estrutural de Anhembi, a aproximadamente 10 km a NW do município homônimo, no estado de São Paulo (SP). A região é caracterizada por afloramentos das formações Teresina (Permiano Inferior) e Piramboia (Permiano Superior a Triássico) (figura 2.5). A área de estudo também é cortada pela represa de Barra Bonita (rio Tietê).

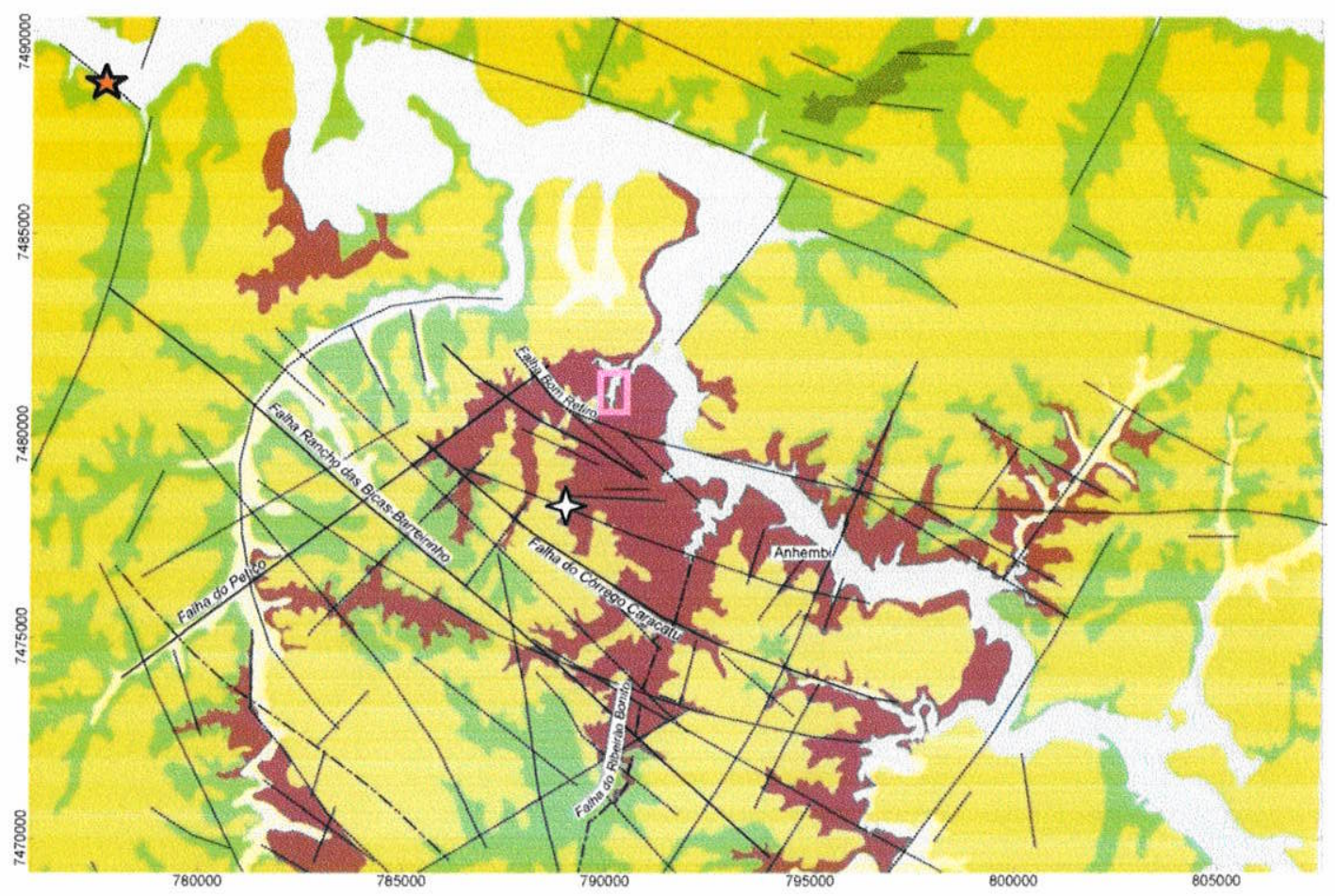

Figura 2.5: Alto Estrutural de Anhembi, com a Formação Teresina em marrom, a Formação Piramboia em verde e, em amarelo, a cobertura Cenozoica. A represa de Barra Bonita está indicada em azul. O local do presente trabalho está indicado pelo retângulo rosa. A área onde ocorrem os cones silicosos. A estrela branca indica a localização do poço 1-AB-1-SP da Petrobrás, enquanto que a estrela vermelha indica onde ocorrem arenitos asfálticos. Modificado de Araújo (2006) e Cavallaro (2013). 
O Alto Estrutural de Anhembi apresenta topografia relacionada com a litologia das formações aflorantes, sendo que para a Formação Teresina o relevo observado é de colinas suaves com encostas em degraus. Este fenômeno é causado por leitos de calcário e sílex presentes na região (IPT, 1979 apud Cavallaro, 2013).

Os principais litotipos da Formação Piramboia na região são basicamente arenitos finos a médios de coloração amarelada. Apresentam diferentes graus de argila e tanto laminações cruzadas como plano-paralelas, geralmente em associação com siltitos arroxeados. O ambiente de deposição inferido para essa formação é de um depósito eólico de dunas, entredunas e lençóis de areia, com influência menor de depósitos fluviais (Assine e Soares, 1995; Caetano Chang e WU, 1995 apud Cavallaro, 2013).

Os principais litotipos da Formação Teresina na região são siltitos e argilitos amarelados e avermelhados com intercalações carbonáticas e níveis de sílex e coquinas (IPT, 1979 apud Cavallaro, 2013). Embora a presença dessas coquinas seja observada, não existem estudos sobre os fósseis presentes na região do Alto Estrutural de Anhembi, tampouco trabalhos sobre a relação em que os fósseis dessa região teriam com os cones silicosos aflorantes pertencentes à Formação Teresina, recentemente interpretados por Yamamoto et al. (2005) como depósitos de um antigo sistema hidrotermal que estava presente na região.

Rohn (1994) compilou registros paleontológicos dentro de um esquema bioestratigráfico que demonstra correlações entre pacotes de rochas do Grupo Passa Dois no estado de São Paulo. Nesse caso foi registrada a ocorrência dos cones silicosos, então classificados como possíveis estromatólitos (Ragonha e Soares, 1974), e carófitas próximos da base da biozona Pinzonella neotropica. 


\section{O EVENTO HIDROTERMAL DE ANHEMBI (SP)}

Ocorrem, na Formação Teresina (Grupo Passa-Dois, Bacia do Paraná), a mais ou menos 10 quilômetros $(\mathrm{Km})$ a noroeste da cidade de Anhembi (SP), mais de 4.500 estruturas dômicas a cônicas (figuras 3.1 e 3.2) compostas de sílica praticamente pura, que atraíram a atenção de vários pesquisadores (Soares e Ragonha, 1974; Yamamoto et al., 2005; Araújo, 2003; Cavallaro, 2013), mas apenas recentemente um modelo satisfatório para sua gênese foi apresentado (Yamamoto et al., 2005).

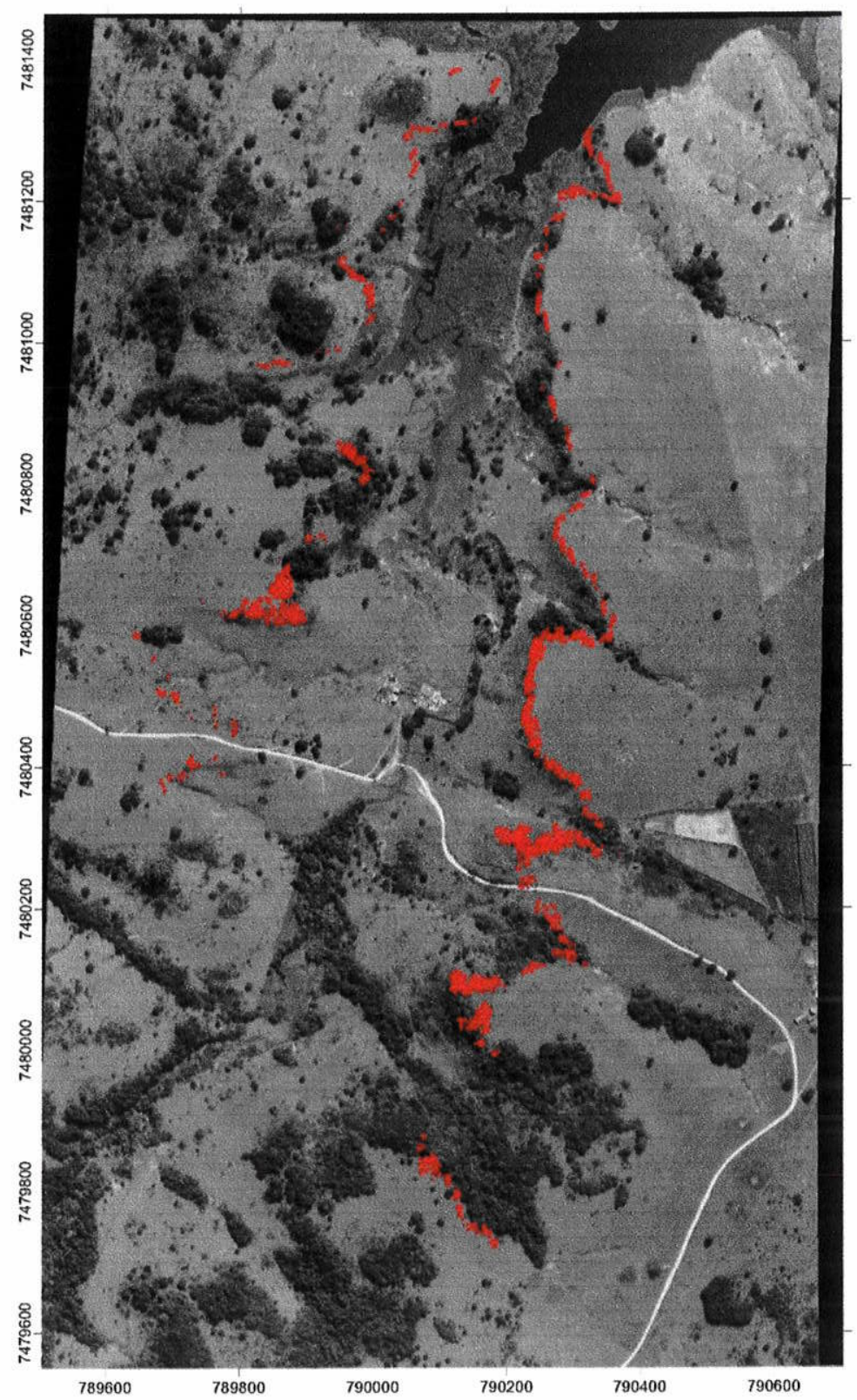

Figura 3.1: Imagem aérea da região onde ocorrem os cones silicosos, no Vale do Córrego do Retiro, com os pontos vermelhos indicando a posição de cada um individualmente. Retirada de Yamamoto et al. (no prelo) 


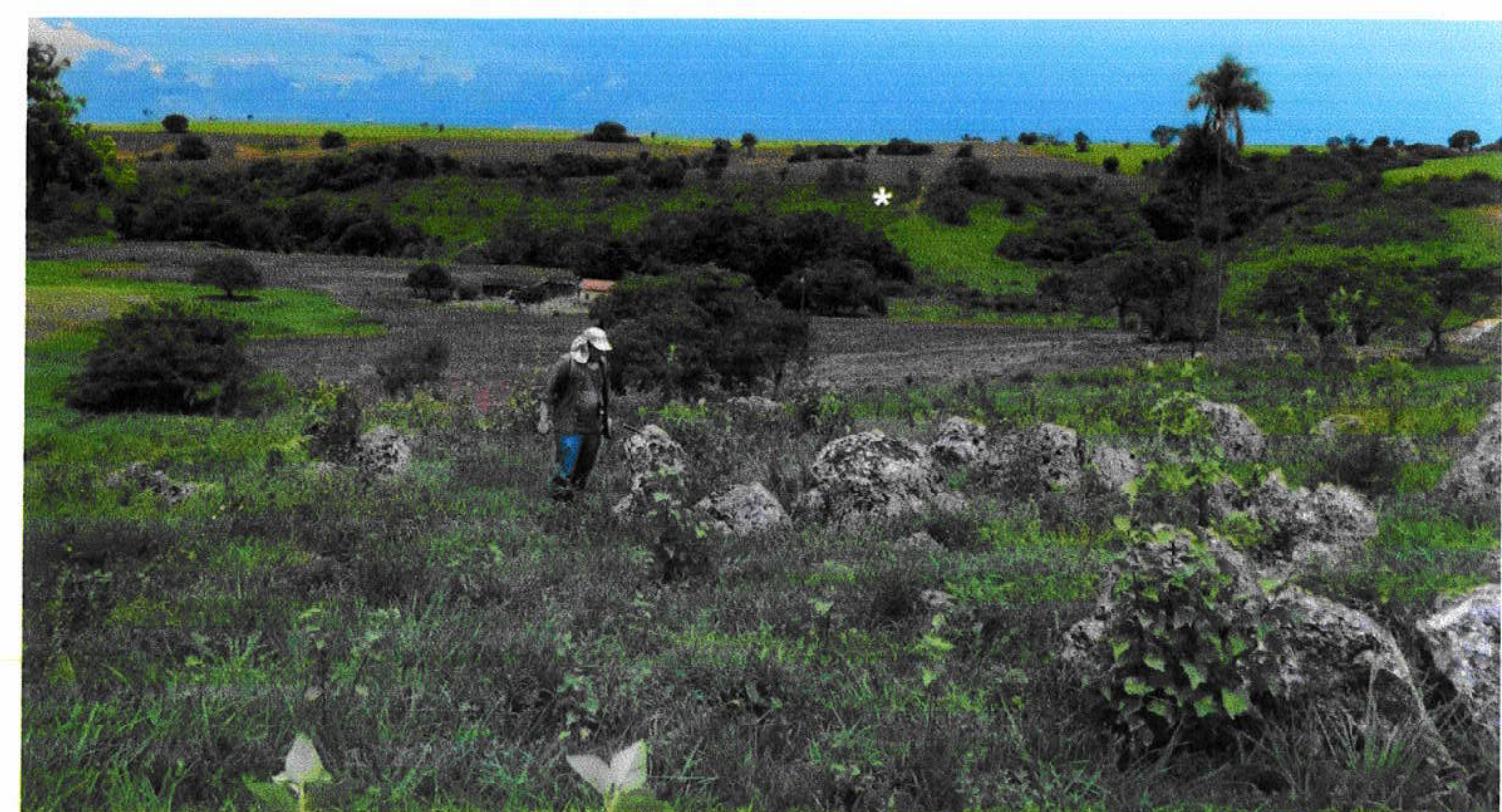

Figura 3.2: Vista para E da região de estudo em Anhembi (SP). Notar o tamanho das estruturas cônicas. O asterisco branco o nível equivalente do outro lado da drenagem do Córrego do Retiro.

Segundo Yamamoto et al. (2005), estas estruturas apresentam morfologia dômica a cônica, são arredondadas, com superfície lisa, alto relevo e de 0,2 a $4 \mathrm{~m}$ de largura (em média $0,85 \mathrm{~m}$ ) e até $1,9 \mathrm{~m}$ de altura. Podem ocorrer individualmente ou em grupos de quatro ou mais (figura 3.3). $\mathrm{O}$ processo de exumação expôs a estrutura interna de muitos cones. Sua parede externa é maciça enquanto o centro é geralmente oco ou extremamente vesicular e se estende em toda a altura da estrutura. Quase todos os cones possuem uma abertura apical, a qual às vezes possui um tampão vesicular. Finalmente, em muitos cones pode-se notar a presença de siltito preenchendo a porção central.

A rocha é um silexito cinza-claro com abundantes vesículas e espaços vazios geralmente preenchidos parcialmente por sílica botrioide e cristais de quartzo grossos. Não se observa nenhum tipo de estratificação nos cones, a não ser uma possível concentricidade incipiente evidente em alguns indivíduos raros (figura 3.4) Petrograficamente, a rocha nos cones é predominantemente quartzo microcristalino com textura microssacaroide, juntamente com cristais maiores de megaquartzo. As bordas das vesículas tipicamente estão revestidas por calcedônia fibrorradiada e o espaço restante ou vazio ou preenchido por microquartzo e megaquartzo num arranjo centrípeto. 


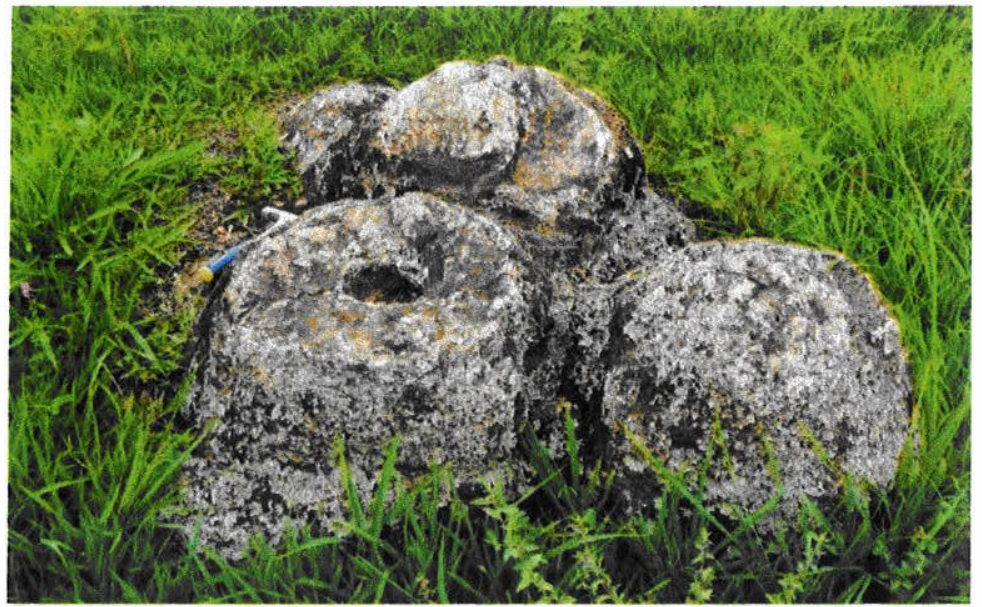

Figura 3.2: Conjunto de três estruturas cônicas agrupadas presentes no Alto Estrutural de Anhembi.

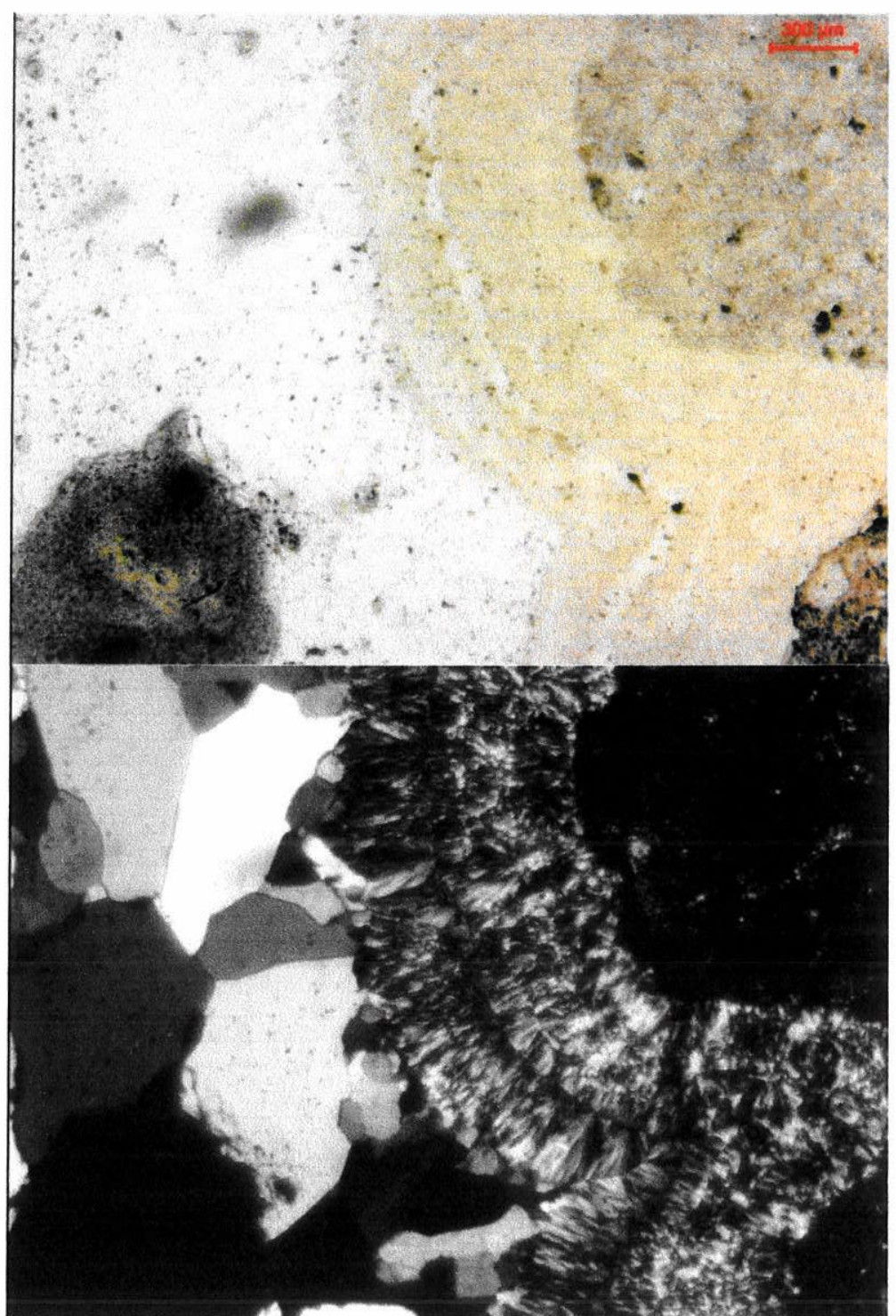

Figura 3.3: Seção delgada da lateral de um dos cones silicosos, primeiro sob luz normal e depois sob luz polarizada. Notar a calcedônia fibrorradiada juntamente com os cristais de quartzo maiores (à esquerda) e a textura microssacaroide (à direita). 
Yamamoto et al. (2005) propuseram a classificação dessas estruturas como sendo depósitos originários de um antigo sistema hidrotermal. A rocha, então, em se tratando de um precipitado primário de origem hidrotermal poderia ser chamada de sínter silicoso. Para basear sua interpretação, os autores levaram em conta o fato (1) das estruturas serem depositadas singeneticamente com o topo da Formação Teresina na região (sedimento terrígeno não está presente dentro das estruturas e os estratos logo abaixo delas estão altamente silicificados), (2) por serem constituídas por sílica pura apresentando relíquias de uma textura opalina, e (3) por apresentarem morfologia semelhante a sistemas hidrotermais modernos, como os presentes no Parque Nacional de Yellowstone nos EUA (Guidry e Chafetz, 2003), em El Tatio, no Chile (Jones e Renaut, 1997) e na região geotermal de Waiotapu, na Nova Zelândia (Jones et al., 1999).

Cavallaro (2013) analisa a principal problemática levantada por Yamamoto et al. (2005), que é a fonte de calor responsável pelo hidrotermalismo da região. O autor procurou, através de métodos geofísicos, identificar a rocha que teria servido como essa fonte de calor na região, porém não a encontrou. Isso sugere que as falhas presentes na região, especialmente aquela em direção ao Córrego do Retiro, serviram como condutos para a água quente vinda do embasamento da região, a cerca de $1650 \mathrm{~m}$. de profundidade. A origem dessa energia térmica seria, então, resultado dos processos de deformação dúctil no interior da crosta e no manto superior.

Os cones anteriormente haviam sido interpretados como estromatólitos (Soares, 1972 apud Yamamoto et al., 2005). Esta interpretação foi descartada pois a ocorrência de estromatólitos coniformes presentes no Fanerozoico é rara (Walter, 1976) sendo que a condição ideal para o seu desenvolvimento (p. ex. Conophyton) seria em águas mais profundas do que o inferido para o local onde estão localizados os cones. Ademais a estrutura concêntrica observada em alguns cones, além de rara, aparenta ser muito grossa e irregular para ser atribuída a laminação estromatolítica (figura 3.4). Somado a isso, não há evidência de uma composição calcária prévia dos cones.

Yamamoto et al. (2005) propuseram também duas outras hipóteses para a ocorrência dos cones: seriam ninhos de insetos fossilizados ou domos de sal. Entretanto, ambas são igualmente improváveis pois os cones são aparentemente estruturas sinsedimentares que sofreram litificação anterior ao soterramento, fato corroborado pelas rochas sedimentares sobrejacentes demonstrarem alguma deformação. 


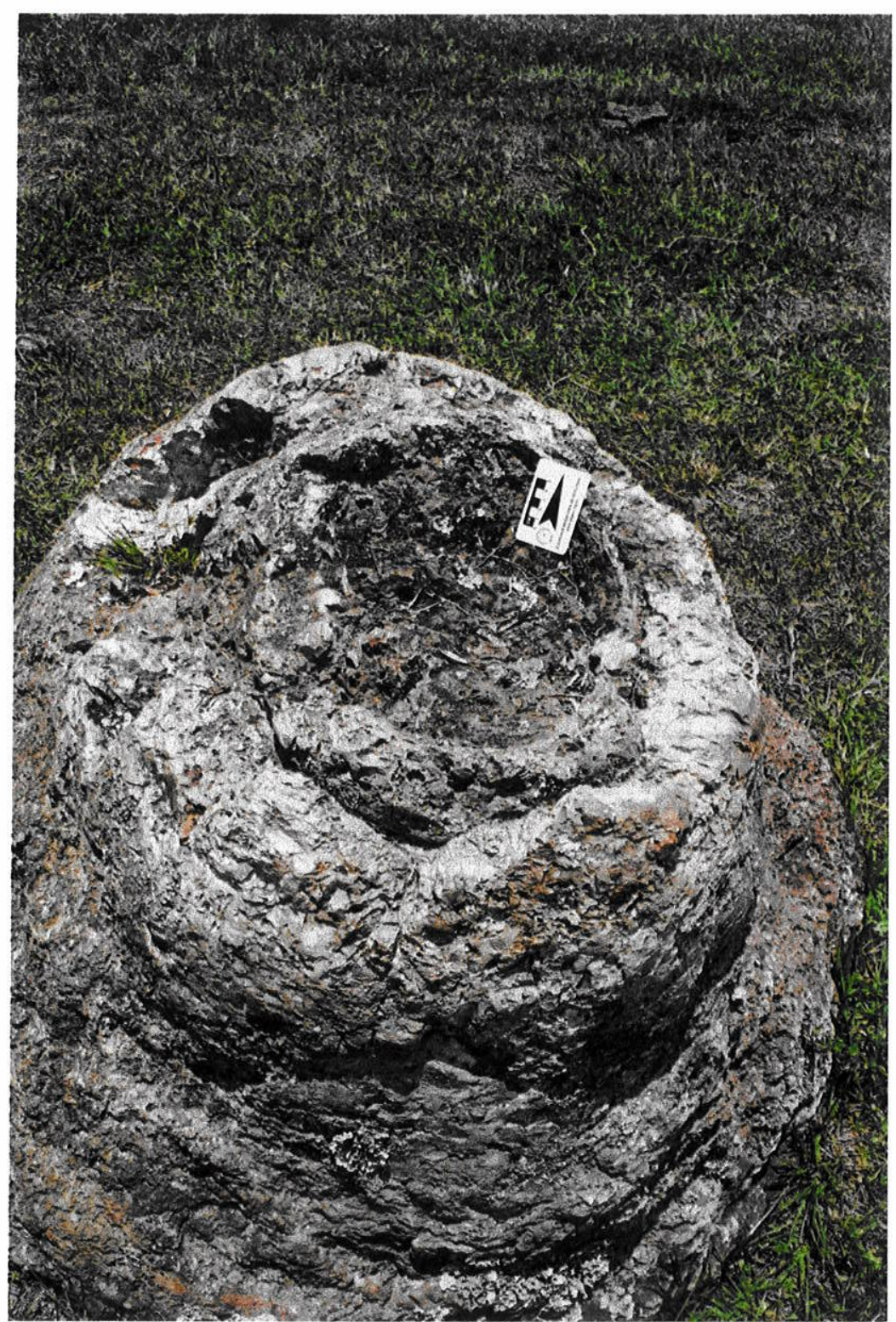

Figura 3.4: Cone silicoso registrando a concentricidade observada por Yamamoto et al. (2005). 


\section{MATERIAIS E MÉTODOS}

\subsection{Trabalho de Campo}

Dois trabalhos de campo foram realizados para fazer observações estratigráficas, sedimentológicas e paleontológicas e coletas na região estudada. As duas saídas tiveram duração de dois dias cada uma, uma no período de 1 a 2 de fevereiro de 2013 e a outra de 13 a 14 de janeiro de 2014. Os afloramentos visitados localizam-se a aproximadamente $10 \mathrm{~km}$ a NW do município de Anhembi, na região de drenagem do Córrego do Retiro, braço da Represa de Barra Bonita (rio Tietê).

Para levantar a seção estratigráfica local, utilizou-se a técnica de visadas (figura 4.1), utilizando-se de uma bússola Brunton com clinômetro. A cada $1,80 \mathrm{~m}$ eram feitas as marcações, totalizando um total de oito marcações em aproximadamente 14,4 m. Nessa sucessão ainda foi identificado o nível de base dos cones, de aproximadamente $30 \mathrm{~cm}$, juntamente com o intervalo de sua ocorrência, que corresponde a outros $1,5 \mathrm{~m}$. Por fim foi analisado o intervalo presente a cerca de $1 \mathrm{~m}$ acima do nível dos cones silicosos, totalizando para a seção estudada no presente trabalho cerca de $17,2 \mathrm{~m}$.

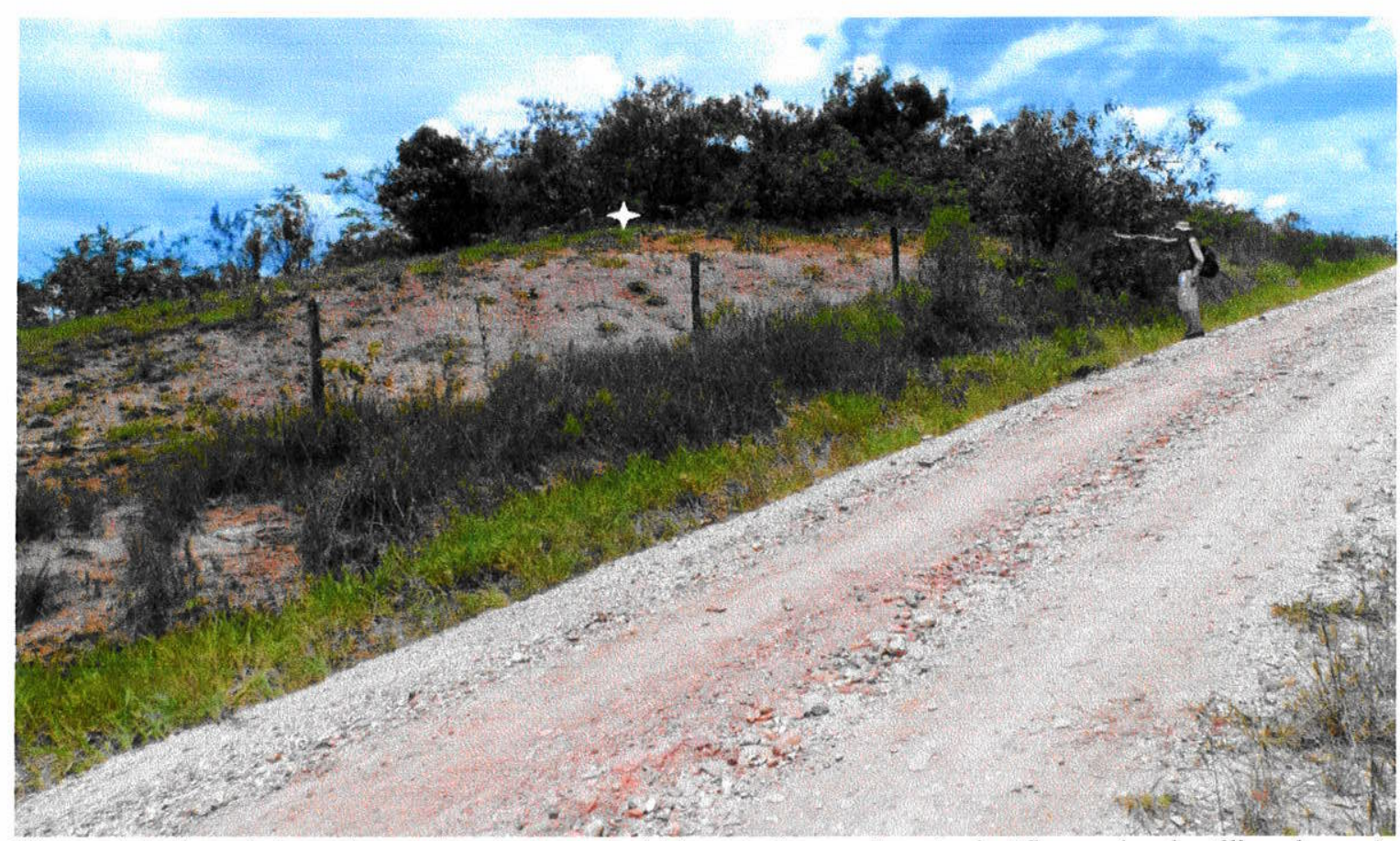

Figura 4.1: Exposição ao longo da estrada onde foi levantada a seção estratigráfica no local, utilizando-se do método de visadas. O facão aponta para o nível onde afloravam os cones silicosos, evidenciados pela estrela branca (Base dessas estruturas).

Ao longo dessa seção estratigráfica foram realizadas coletas de diversas amostras, tanto em níveis estratigraficamente logo abaixo da ocorrência dos cones (figura 4.2) como também em níveis lateralmente contínuos (figura 4.3) e logo acima deles (figuras 4.4 e 4.5), 
sendo coletadas amostras que correspondem a momentos distintos do evento hidrotermal ocorrido. Os níveis abaixo da ocorrência dos cones localizam-se a aproximadamente $25 \mathrm{~cm}$ da base dessas estruturas, enquanto que os níveis lateralmente equivalentes correspondem ao sedimento de até aproximadamente $15 \mathrm{~cm}$ abaixo da superfície das regiões entre cones. Já os níveis acima da ocorrência estão presentes a aproximadamente 1 metro acima do topo dos cones.

Ao total foram coletadas cerca de 29 amostras de todos os níveis analisados ( 5 abaixo, 14 lateralmente contínuas e 10 acima do nível de base dos cones silicosos). Para a análise de estratos mais abaixo desse intervalo foram utilizadas 2 amostras coletadas por pesquisadores anteriores. 


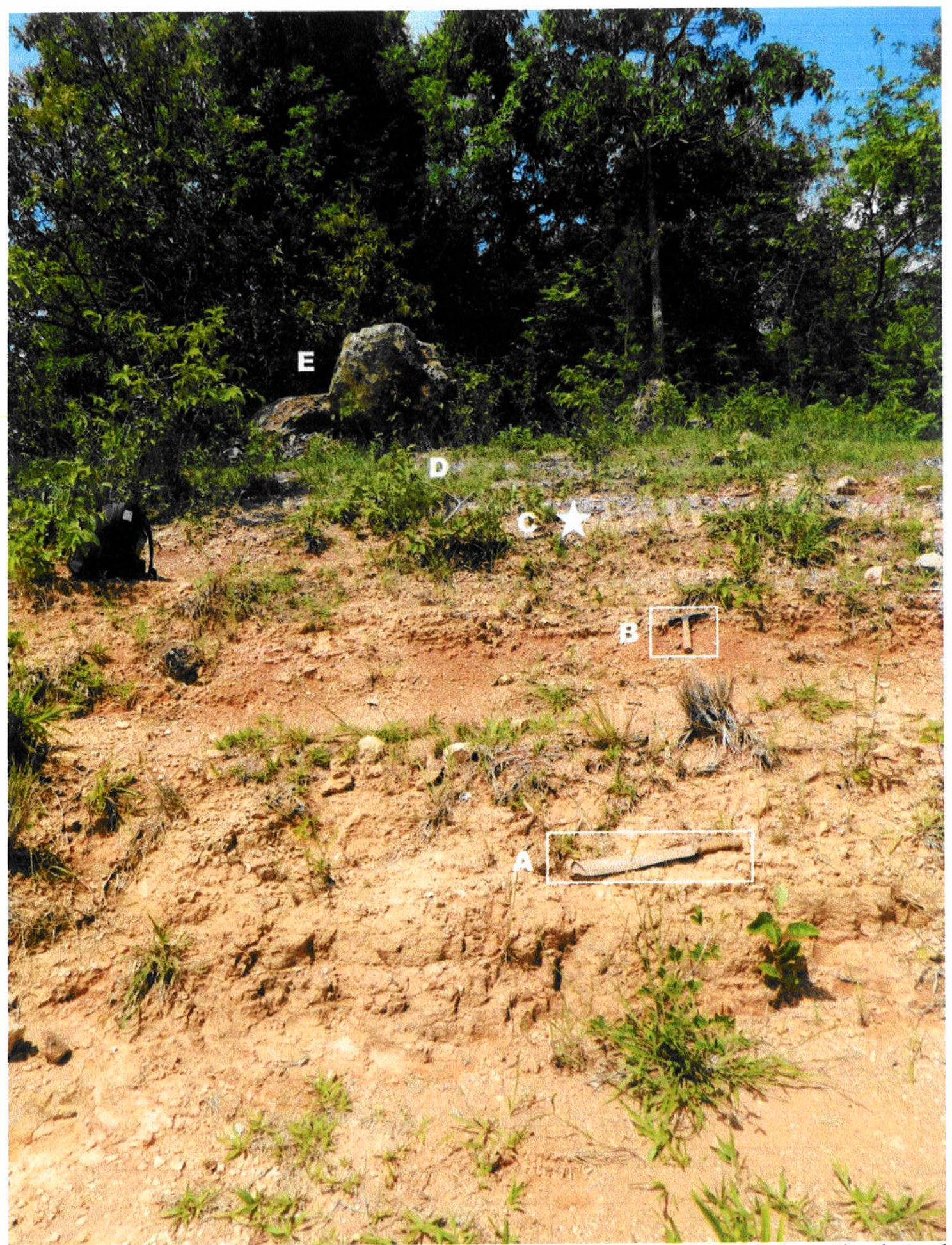

Figura 4.2: Sucessão abaixo do nível dos cones silicosos. $O$ facão (A) corresponde a nível arenítico dentro da sucessão, o martelo (B) representa nível arenítico ligeiramente silicificado, a estrela branca (C) corresponde a outro nível arenítico ligeiramente intemperizado. Em (D) há sedimento lateralmente equivalente à base dos cones silicosos, enquanto em (E) podem-se observar os cones silicosos. 


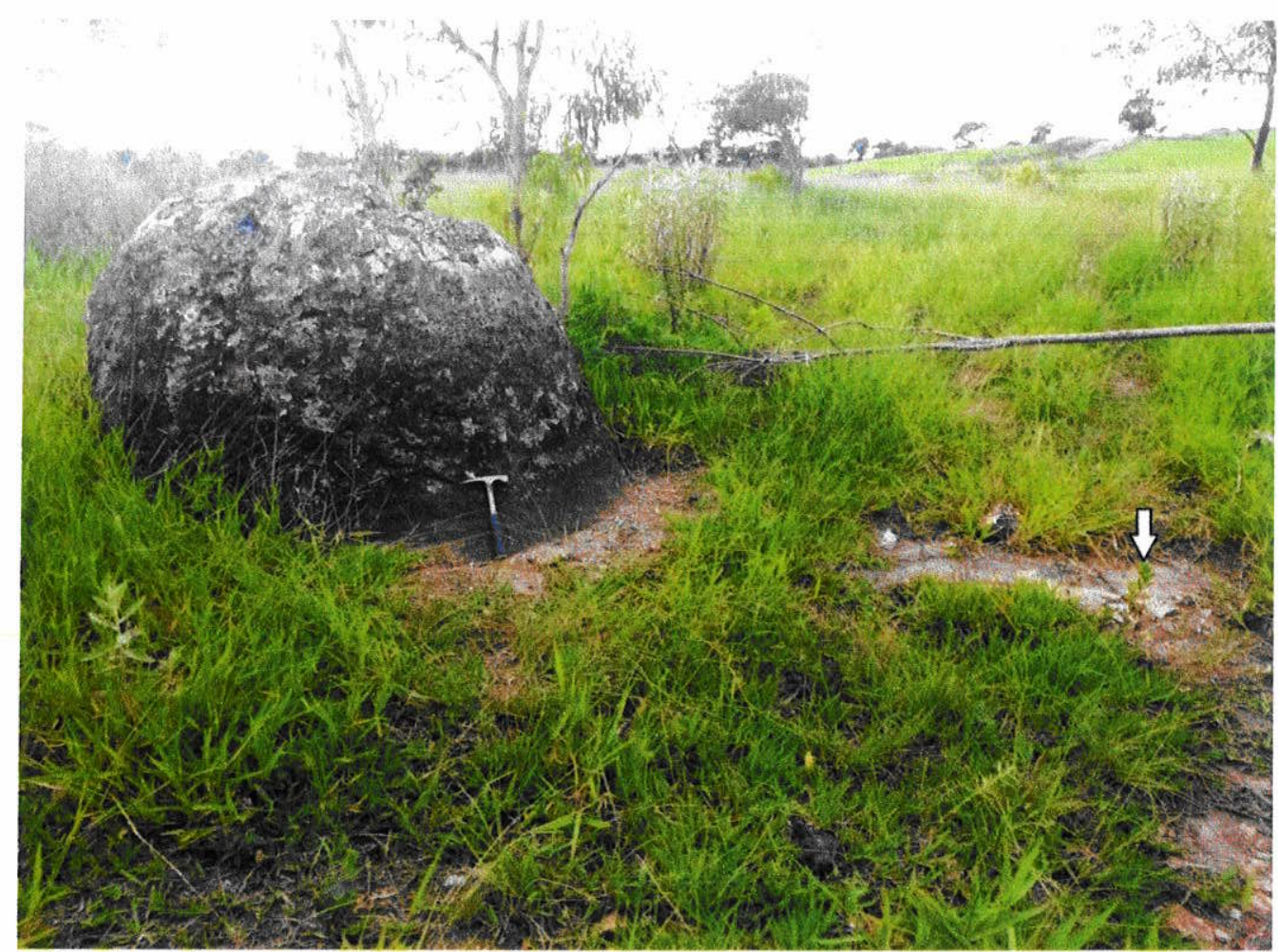

Figura 4.3: Cone silicoso e sedimentos silicificados lateralmente equivalentes à base do cone, indicados pela seta branca à direita. Local de coleta das amostras 3(02.02.13):1, 2 e 3.

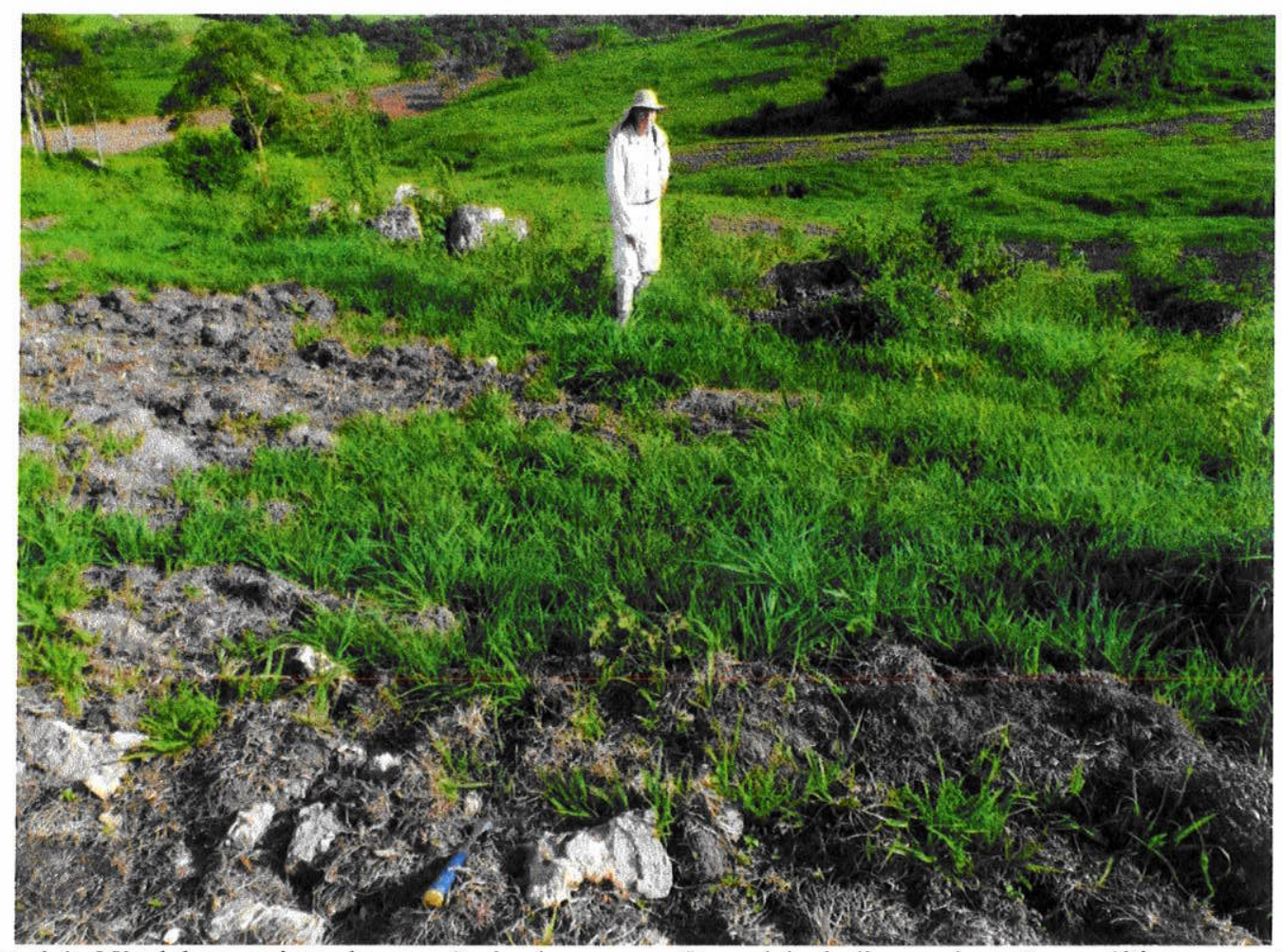

Figura 4.4: Nível logo acima da ocorrência dos cones. O modelo indica onde estão as últimas ocorrências estratigráficas de cones registradas na região e o martelo, na região inferior da figura, indica o nível amostrado. 


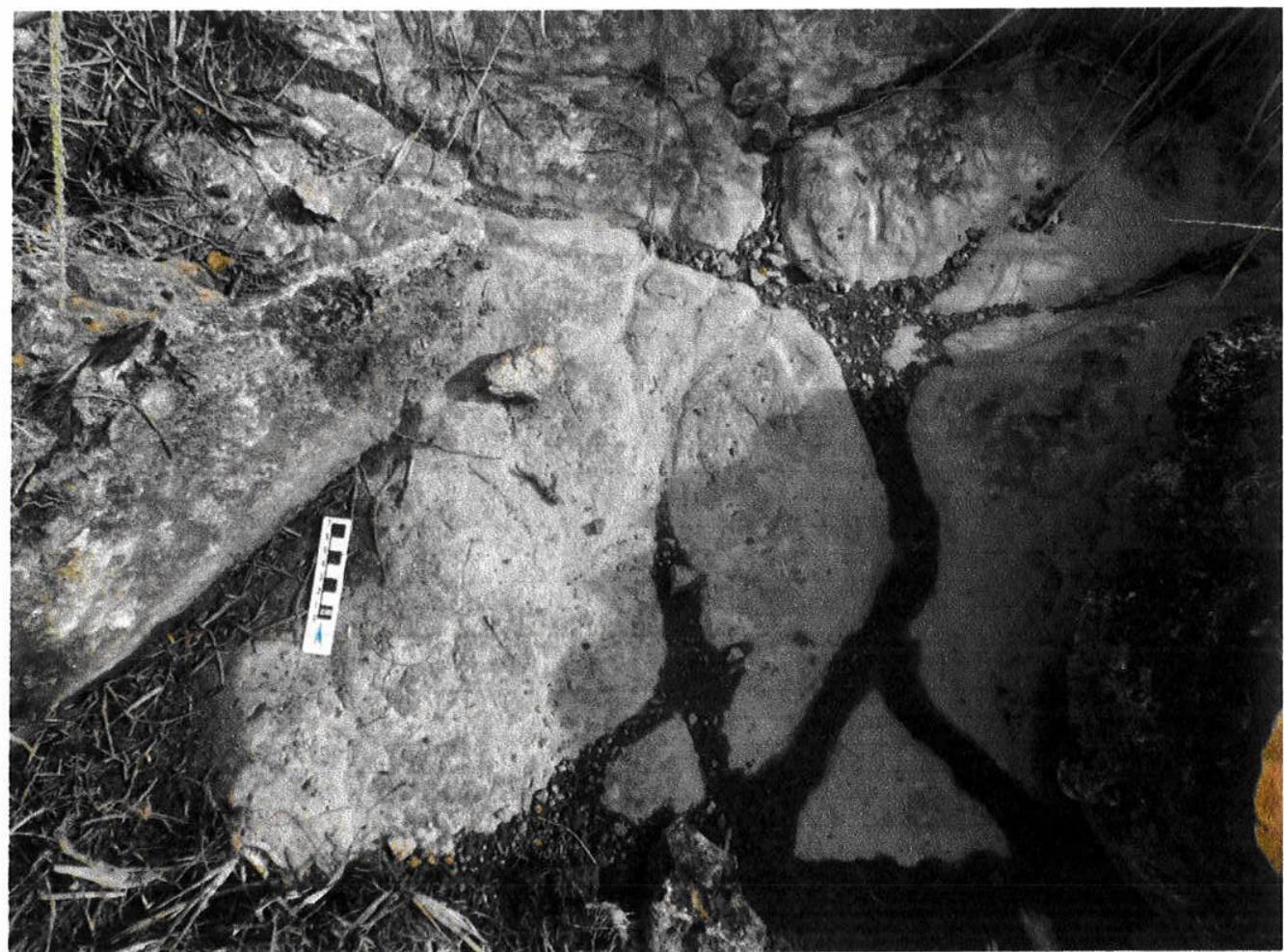

Figura 4.5: Afloramento a aproximadamente 1 metro acima dos cones silicosos. Local indicado pelo martelo na figura 4.4 .

\subsection{Análises Laboratoriais}

Em laboratório, as amostras foram cortadas e 19 seções delgadas (lâminas petrográficas) foram confeccionadas na Seção de Laminação do Instituto de Geociências da USP (IGc-USP) (Quadro I). Também foram analisadas 2 lâminas já produzidas por pesquisadores anteriores que correspondem à parede dos cones silicosos. 
Quadro I: Os códigos das seções delgadas produzidas juntamente com seu nível estratigráfico relativo aos cones, suas coordenadas GPS e seu litotipo baseado nas amostras coletadas.

\begin{tabular}{|c|c|c|c|}
\hline $\begin{array}{l}\text { Ponto / Código de Campo / } \\
\text { Coordenadas UTM }\end{array}$ & $\begin{array}{l}\text { Número de } \\
\text { Amostra }\end{array}$ & $\begin{array}{c}\text { Lâmina } \\
\text { Petrográfica }\end{array}$ & Nível \\
\hline \multirow{7}{*}{$\begin{array}{c}3 / \\
1(13.01 .14) / \\
\text { 22K } 07897407480475\end{array}$} & 7 & $7 \mathrm{~A}$ & \multirow{6}{*}{ Acima } \\
\hline & 6 & $7 \mathrm{~B} 3$ & \\
\hline & 6 & 7B2 & \\
\hline & 6 & 7B1 & \\
\hline & 3 & 4 & \\
\hline & 1 & 3 & \\
\hline & 2 & 2 & \multirow{10}{*}{ Contínuo } \\
\hline \multirow{9}{*}{$\begin{array}{c}2 / \\
3(02.02 .14) / \\
22 \mathrm{~K} 07901767480198\end{array}$} & 6 & PFR-11 & \\
\hline & $5 \mathrm{~A}$ & PFR-10 & \\
\hline & 4 & PFR-9C & \\
\hline & 4 & PFR-9B & \\
\hline & 4 & PFR-9A & \\
\hline & $3 \mathrm{~B}$ & PFR-8 & \\
\hline & $3 \mathrm{~A}$ & PFR-7a & \\
\hline & 1 & PFR-6B & \\
\hline & 1 & PFR-6A & \\
\hline \multirow{3}{*}{$\begin{array}{c}1 / \\
2(14.01 .14) \\
\text { 22K } 07901247480304\end{array}$} & 10 & 10 & \multirow{3}{*}{ Abaixo } \\
\hline & 5 & 5 & \\
\hline & 4 & 4 & \\
\hline
\end{tabular}

A análise microscópica das seções delgadas foi realizada em microscópio petrográfico do Laboratório de Estudos Paleobiológicos do IGc-USP. As figuras dos microfósseis encontrados foram obtidas no Laboratório de Petrografia Sedimentar do IGc-USP e posteriormente tratadas com o programa Photoscape.

A nomenclatura das rochas carbonáticas segue a proposta de Dunham (1962) posteriormente ampliada por Embry e Klovan (1971). 


\section{RESULTADOS}

A estratigrafia local é dominada por camadas de pelitos, siltitos e arenitos finos amarelados a avermelhados (cor de alteração intempérica), de modo geral pouco fossilíferas. Foi levantada uma seção (figura 5.1) nos afloramentos próximos à estrada de terra que cruza a região. Esta sucessão termina no nível dos cones silicosos, mas foi complementada por observações estratigráficas feitas até pouco mais de um metro acima dos cones do outro lado do Córrego do Retiro. O resto da seção estratigráfica foi completada por informações apresentadas por Ragonha e Soares (1974).

A

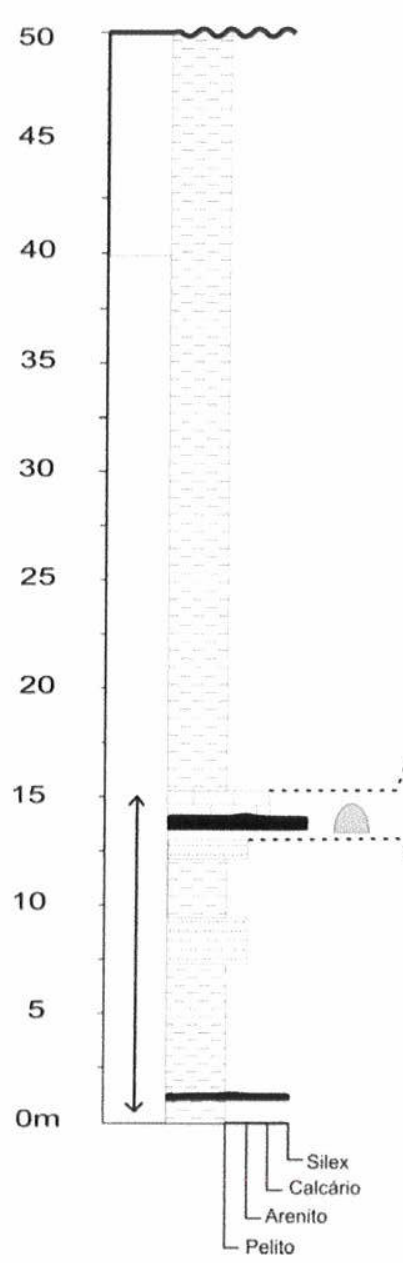

\section{B}

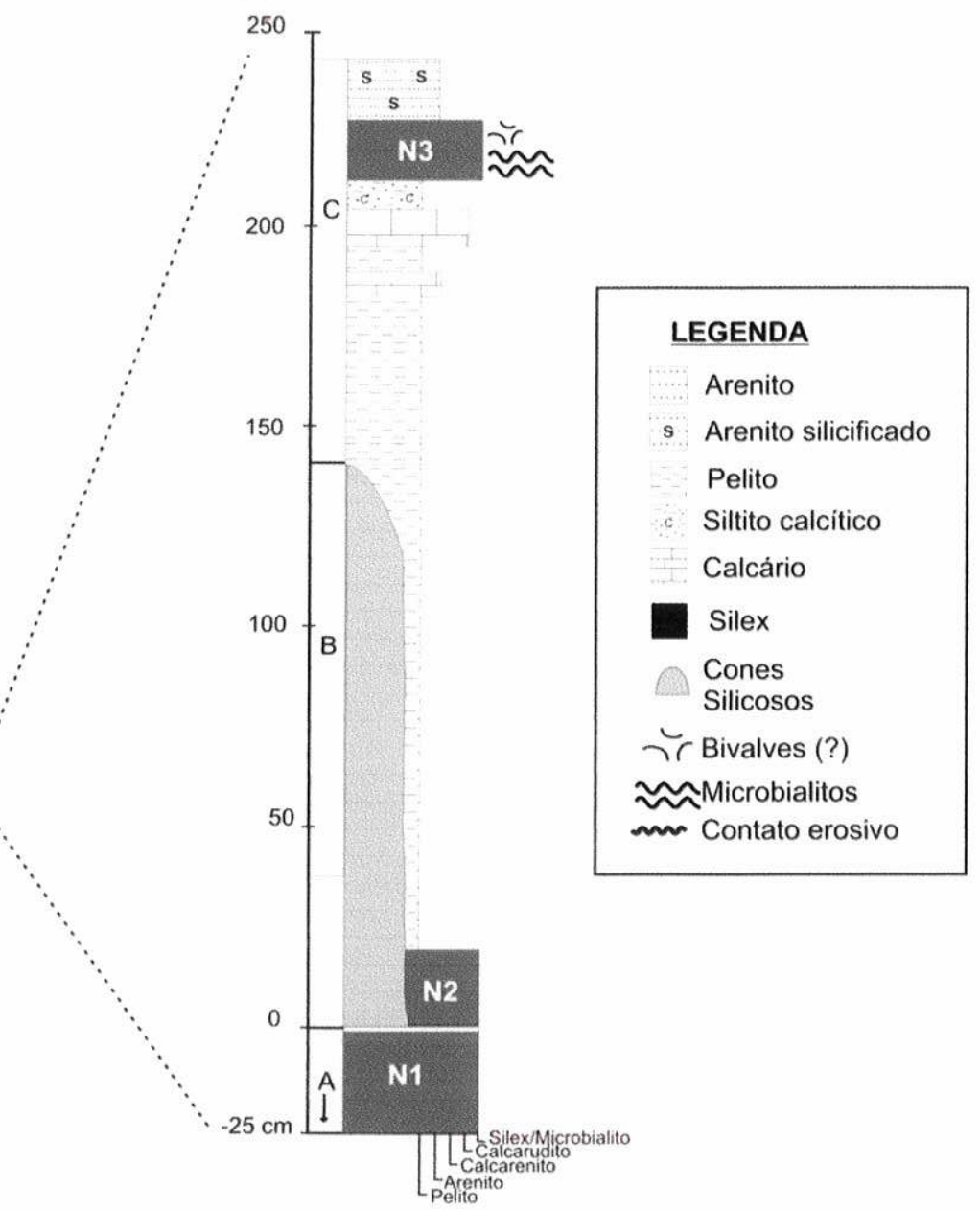

Figura 5.1: Seção estratigráfica da região estudada no presente trabalho. Foi obtida a partir dos dados coletados em campo e complementada por seção da mesma região realizada por Ragonha e Soares (1974). Em (A) as setas indicam a seção levantada e em (B) detalha o topo do Intervalo A e os intervalos B e C, indicando a posição dos níveis de sílex 1, 2 e 3 investigados nesse trabalho. 
A seção de interesse, que se estende desde logo abaixo até logo acima do nível dos cones silicosos, foi subdividida em três intervalos que correspondem à sucessão abaixo do nível dos cones (Intervalo A), o intervalo lateralmente contínuo aos cones, inclusive os estratos pelíticos / síltiticos que preenchem o espaço entre cones (Intervalo B), e a sucessão até aproximadamente 1 metro acima das últimas ocorrências estratigráficas de cones (Intervalo C). Em cada intervalo foram identificados estratos estreitos chaves, aqui designados "Níveis 1, 2 e 3," respectivamente, cada qual caracterizado por silexitos, e adequado para o estudo paleontológico mais detalhado, principalmente por microscopia petrográfica. O nível lateralmente equivalente à parte basal dos cones silicosos (Nível 2) assim como o nível logo abaixo dele (Nível 1) apresenta silicificação muito intensa. Pouco acima dos cones ocorre outra camada chave de rocha calcária também silicificada (Nível 3), mas menos intensamente do que os outros dois níveis. As rochas carbonáticas (substituídas ou não por sílica) nestes níveis e em outra no Intervalo A apresentam fósseis de ostracodes, moluscos bivalves e microbialitos (oncoides). Já nos níveis siliciclásticos, a única ocorrência de fósseis foi um bone-bed com restos de peixes com destaque para um dente de peixe dipnoico bem maior que os outros restos.

\subsection{Intervalo A e Nivel 1}

O Intervalo A consiste numa sucessão de 14,4 m, inicialmente, de siltitos e pelitos que culmina, nos $2 \mathrm{~m}$ finais, em estratos de arenitos finos, no topo, e carbonatos que precederam os cones silicosos. Intercalado nas rochas siliciclásticas finas próximo da base da seção levantada, a aproximadamente 13,5 m abaixo da base dos cones, ocorre por uma camada muito fina de silexito $(2 \mathrm{~cm})$, que parece corresponder ao primeiro dos dois intervalos silicosos descritos na seção de Ragonha e Soares (1974), o outro nível sendo o dos cones. Foi nesse intervalo que aqueles autores fizeram a importante descoberta de fósseis de carófitas, uma alga verde não marinha. Intervalo A termina no Nível 1, uma estreita sucessão de rochas intensamente silicificadas (com até $25 \mathrm{~cm}$ de espessura) encostado na base cones. Foram analisadas neste estudo amostras deste nível, mas serão descritas primeiro uma coquina e um bone-bed de posições mais baixas na sucessão, coletadas por pesquisadores anteriores 300 a 400 m não norte da seção levantada nesse trabalho (Fairchild, comunicação verbal), que fornecem uma ideia parcial da vida no local anteriormente ao evento hidrotermal.

A primeira destas amostras é uma coquina oolítica (figura 5.2), contendo os moluscos bivalves (Cowperesia sp. e Jacquesia sp.) agora substituída por sílica. Apresenta pelo menos $5 \mathrm{~cm}$ de espessura, sem acamamento interno evidente. Conchas inteiras concentram-se na 
parte superior, sendo que o maior exemplar (Jacquesia sp.) mede 1,8 cm de comprimento por $1,1 \mathrm{~cm}$ de altura. Neste nível, a amostra apresenta características de um rudstone oolítico fossilífero, na qual a maioria das conchas é inteira (ou quase) e todas são desarticuladas com o lado convexo da concha voltada para cima, sem, no entanto, nenhuma indicação de orientação preferencial no plano da camada. Ocorre um exemplo de imbricação de três conchas finas e outro de quebra por compactação. Apesar de silicificadas, a maioria das conchas ainda conservam suas linhas de crescimento; poucas exibem evidências de abrasão. $\mathrm{O}$ que, à primeira vista, parecem ooides provavelmente são grãos revestidos, pois variam muito em formato desde fusiforme a equidimensional, e muito poucos são esféricos. Todos são arredondados com tamanho entre areia média e areia grossa $(250 \mu \mathrm{m}$ a $1 \mathrm{~mm})$, mas o arcabouço da rocha é sustentado pelas conchas. Não há, neste nível nem no resto da amostra, intraclastos ou sedimentos siliciclásticos. Moluscos bivalves parecem ser os únicos fósseis presente na coquina. Uma matriz micrítica não é evidente nesta porção da amostra.

$\mathrm{Na}$ base da camada, a situação é outra. Todos os bioclastos são fragmentos de bivalves com exceção de um ou dois moldes externos de conchas quase inteiras. Assim, o arcabouço próximo da base da camada consiste praticamente só de grãos revestidos e bioclastos menores que 1,5 mm (areia muito grossa), até areia fina ou até silte. Pode-se ver, nessa parte da camada, matriz micrítica, agora completamente silicificada, igual aos outros componentes da rocha. 


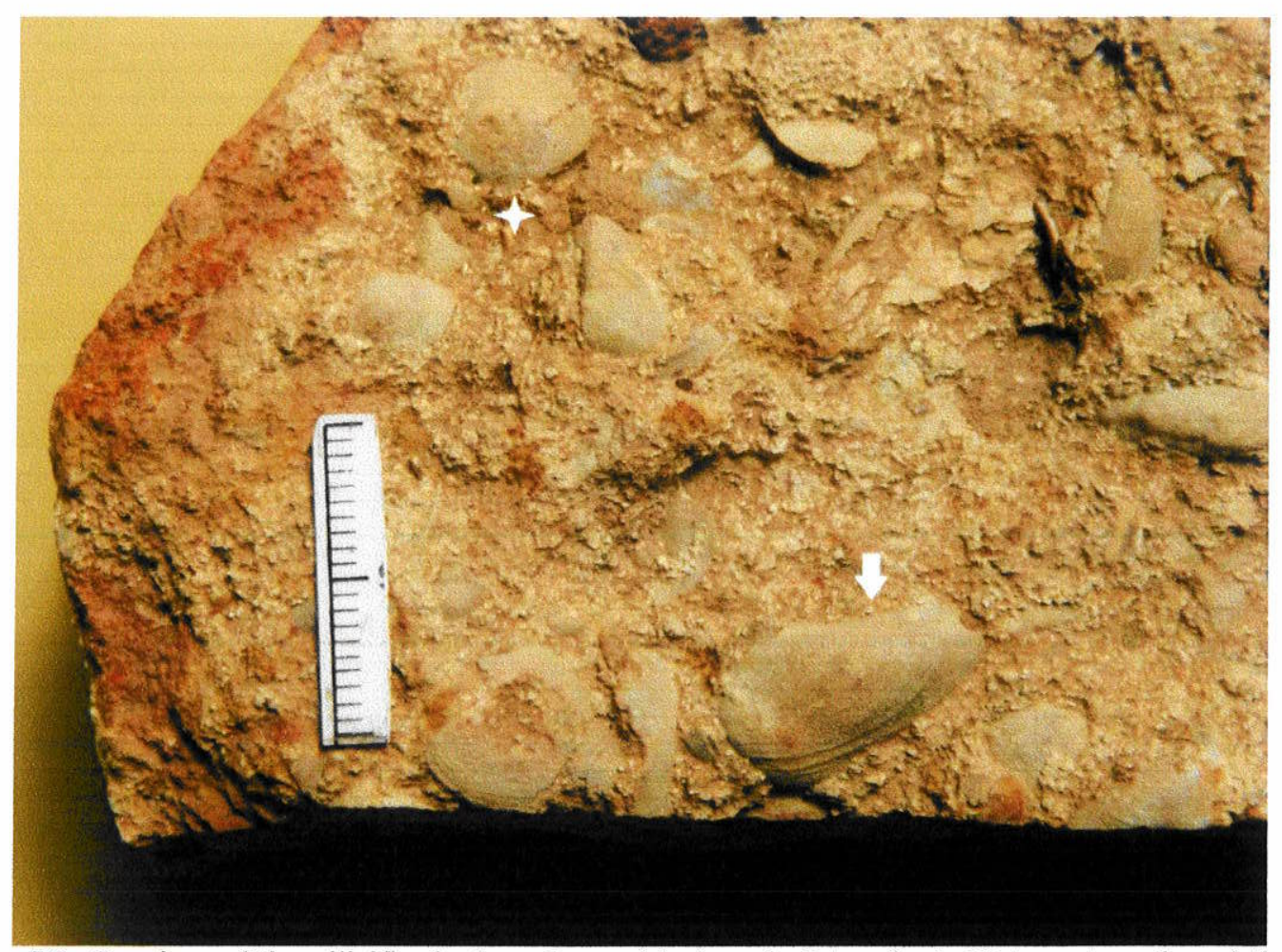

Figura 5.2: Coquina oolítica silicificada de moluscos bivalves do Intervalo A. Notar o tamanho relativo das conchas presentes e os fragmentos biogênicos ao seu redor. A estrela indica concha de Cowperesia sp. e seta branca, uma concha de Jacquesia sp.

A outra amostra é um bone-bed com restos de peixes (figuras 5.3 e 5.4). Ela consiste em uma camada de $1,2 \mathrm{~cm}$ de espessura de arenito grosso a muito grosso composto por grãos (bioclastos de restos de peixes), que variam dentre 0,5 e $1,5 \mathrm{~mm}$. Esses bioclastos são escamas inteiras ou fragmentadas com raros dentes cônicos finos. Estes fósseis constituem o arcabouço da rocha e areia muito fina e silte compõem a matriz em proporção aproximadamente igual à do arcabouço. Destacam-se na amostra dois intraclastos placoides de arenito muito fino derivados da camada inferior com 1 a $2 \mathrm{~cm}$ de comprimento e um dente de peixe dipnoico com 2,8 cm de comprimento e 2,0 cm de altura. Embora parte deste dente fosse perdida na coleta, é evidente, pelo molde externo e pelo fragmento que restou, que o dente foi depositado inteiro sem abrasão aparente. As escamas são em sua maioria inteiras e muitas aparentam arredondamento de suas arestas por abrasão. Todas são espessas (escamas ganoides) e muitas exibem formato losangular, feições que permitem atribuí-las ao grupo dos peixes paleoniscídeos. Os dentes finos devem pertencer ao mesmo grupo. Esta camada se assenta em contato erosivo sobre outra de arenito muito fino afossilífero com pelo menos 2 $\mathrm{cm}$ de espessura e laminação pouco evidente. Ambas as camadas efervescem moderadamente com ácido clorídrico diluído, o que sugere a presença de cimento calcítico. As duas camadas 
diferem dramaticamente em cor, marrom muito claro no arenito inferior e vermelho acastanhado no bone-bed.

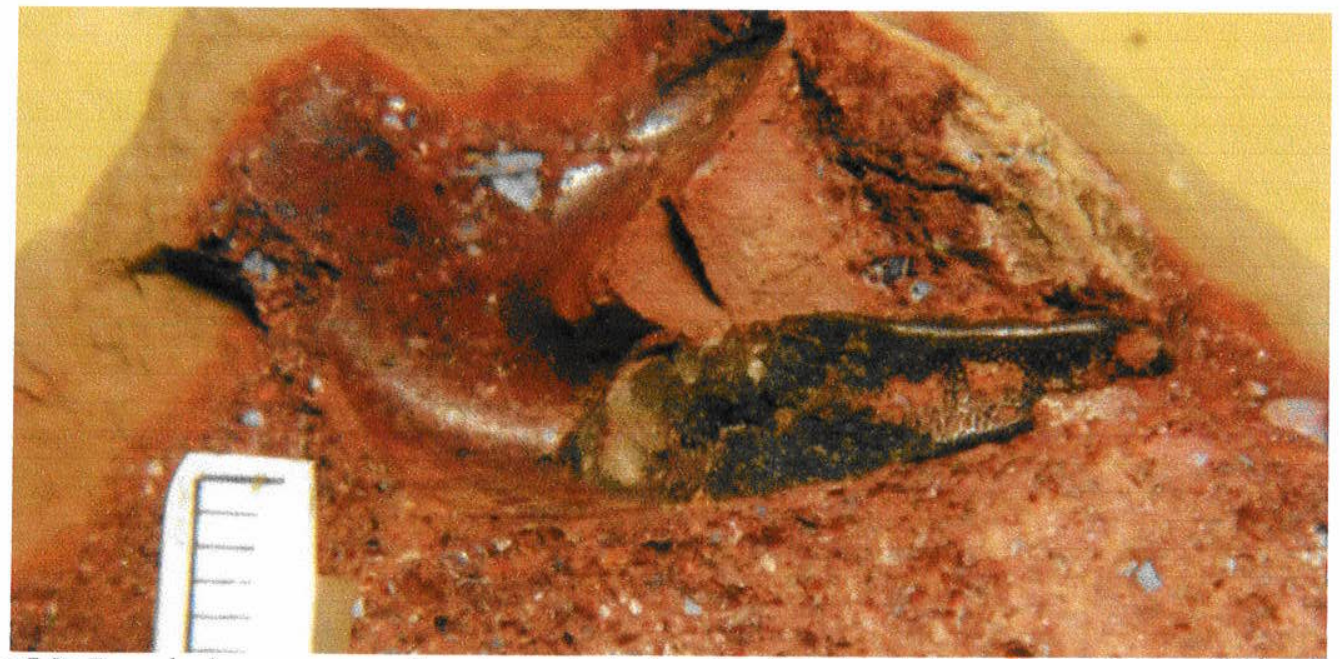

Figura 5.3: Bone-bed com escamas de peixes e dente de peixe dipnoico do intervalo A. O dente foi fragmentado e parte dele perdida na coleta. Mesmo assim, o molde externo indica que o dente foi depositado inteiro.

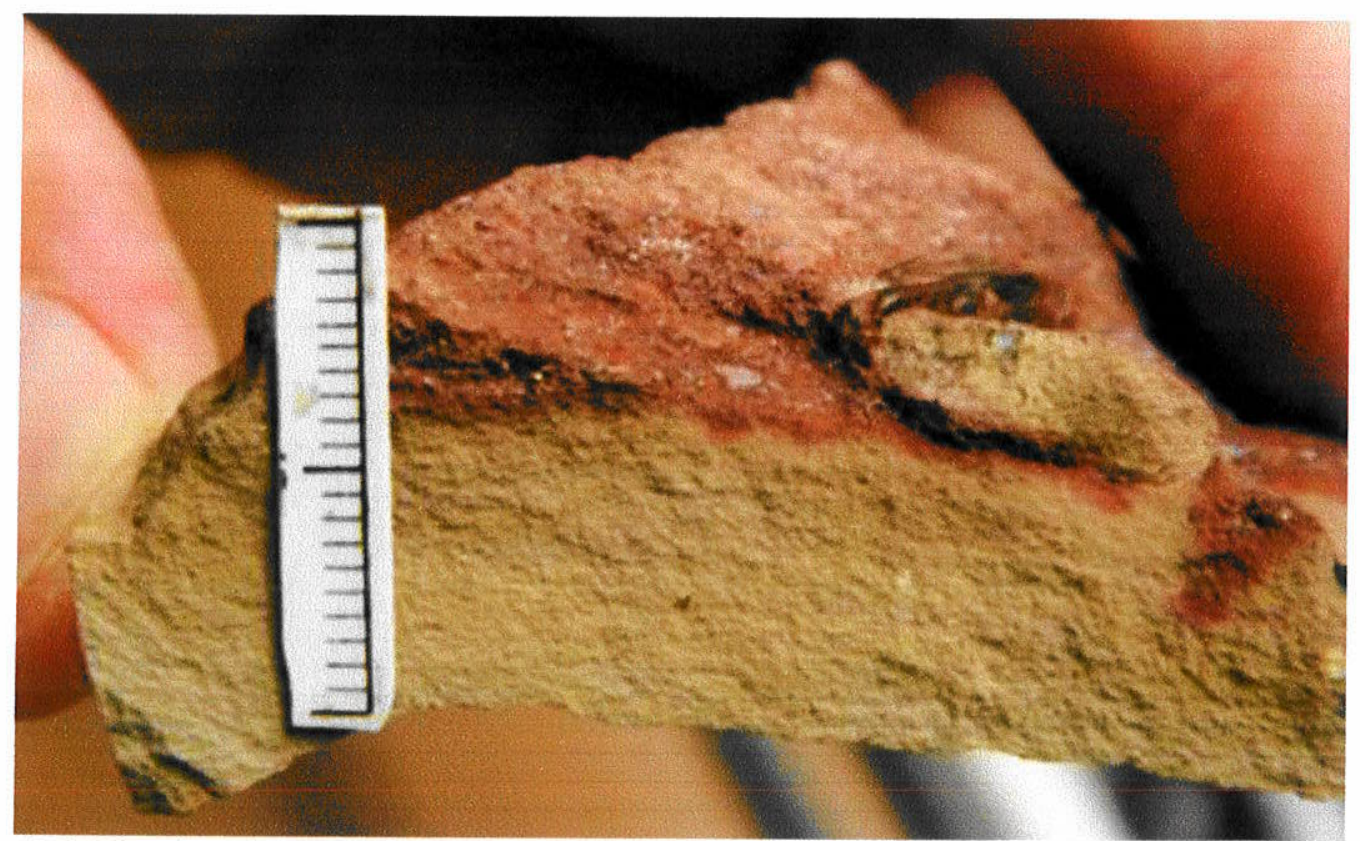

Figura 5.4: Vista lateral da amostra contendo o bone-bed. A parte inferior é um siltito ou arenito fino calcífero mais amarelado. O bone-bed, que é tingida por óxidos de ferro, se assenta sobre o arenito fino em contato erosivo, e é bem mais grosso por causa da concentração de escamas e dentes. Observar o intraclasto na base do bone-bed a direito que foi erodido do arenito fino.

Nas camadas mais acima desse intervalo, logo abaixo da base dos cones e com espessura de $25 \mathrm{~cm}$ (Nível 1), o que se observa são calcários, agora substituídos por sílica, do tipo grainstones de partículas arredondadas com tamanho entre areia muito fina a areia média 
(0,09 a 0,5 mm). Os grãos presentes não são ooides. Ocorrem bolsões irregulares com grãos menores. Esses carbonatos foram substituídos por sílica (microquartzo com textura microssacaroide, quase críptica) e os poros presentes na época da silicificação foram preenchidos por leques de calcedônia fibrorradiada (sem megaquartzo).

A preservação nessas rochas é muito variada, apresentando padrão irregular, designado aqui de "mosqueado", com aspecto de "nuvens" porções da rocha de preservação semelhante em contato com outras porções (ou "nuvens") de preservação diferente. Em algumas áreas, os componentes originais da rocha são claramente evidentes, embora a substituição pareça ter apagado detalhes; outras regiões são apagadas, incolores, transparentes, só com os contornos dos componentes preservados. A rocha apresenta aspecto "sujo" em lâmina que é dado pela grande quantidade de minerais muito pequenos, opacos, muito dos quais com contornos quadrados sugestivos de pirita. Outros pontos escuros mostram formatos diferentes, aparentando ser, pelo menos em parte, alvéolos. Nessas camadas existem fraturas (figura 5.5) que apresentam silicificação mais intensa ao seu redor.

No Intervalo A foram encontradas conchas de bivalves, valvas de ostracodes, oncoides e uma ocorrência de dente de peixe dipnoico. As conchas de bivalves (figura 5.5), analisadas em seções delgadas do Nível 1, estão intensamente silicificadas. Além disso, apresentam-se desarticuladas e seu tamanho aproximado é de $600 \mu \mathrm{m}$ de comprimento e $65 \mu \mathrm{m}$ de espessura. Não estão evidentes ornamentação nem fragmentação e ocorrem esparsas nas lâminas, sendo encontrados poucas delas nessas amostras. 


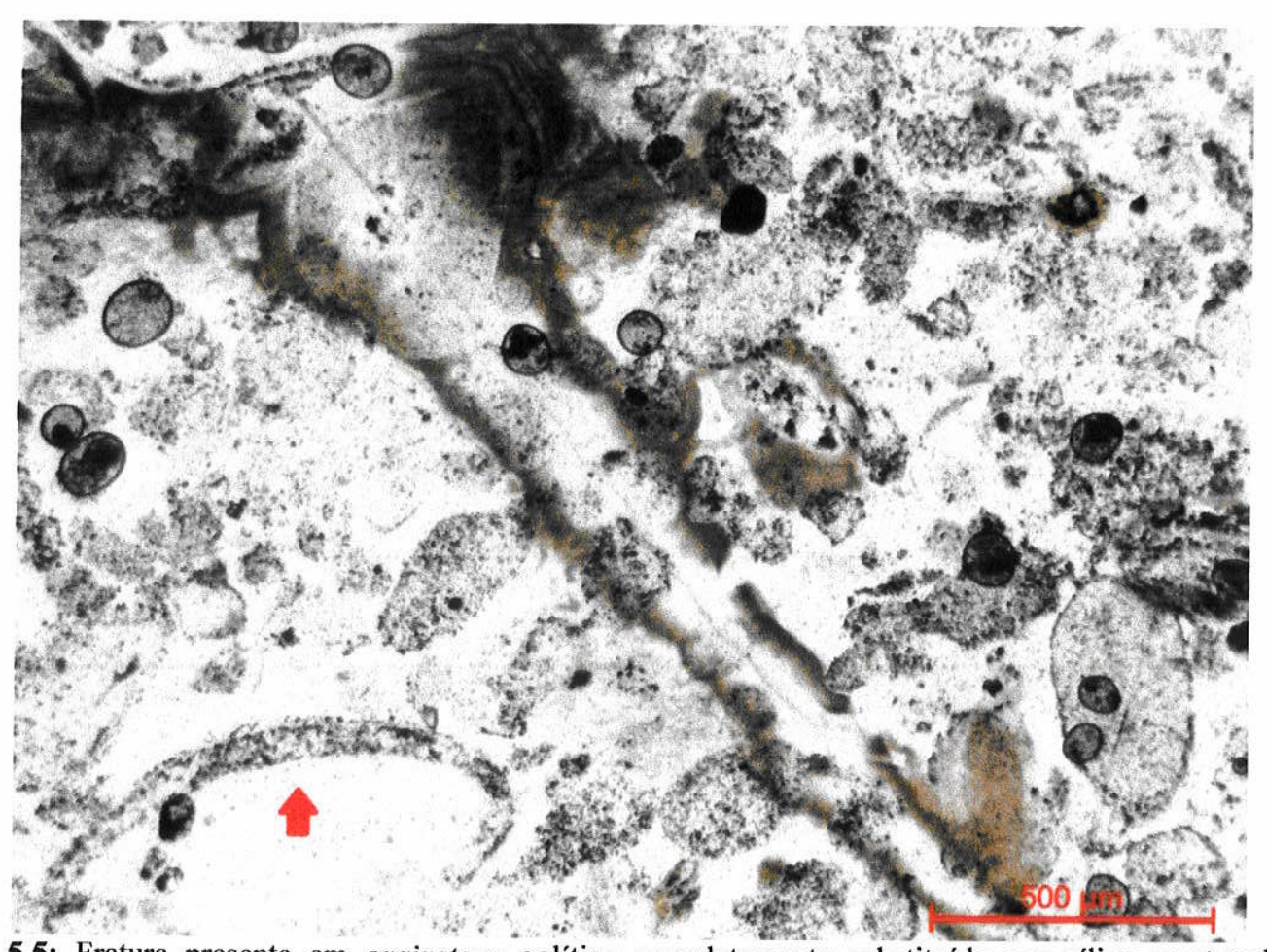

Figura 5.5: Fratura presente em grainstone oolítico completamente substituído por sílica mostrando uma segunda fase de silicificação ao seu redor. Seta vermelha indica vestígios de uma concha de molusco bivalve.

As valvas de ostracodes foram identificadas baseando-se em Scholle (1978), segundo o qual elas apresentam estrutura prismática interna de suas vaívas quanco vistas em seçaơ delgada. As valvas se apresentam desarticuladas em sua maioria (figura 5.6), com apenas afguns exemplares ainda articulados (figura 5.7). Não exibem orientação preferencial nem ocorrem em concentrações da mesma lâmina. Por terem sido analisados em seções delgadas, não foi possível determinar com absoluta segurança algumas de suas características tafonômicas. $\mathrm{O}$ tamanho desses fósseis é de, aproximadamente, 400-500 $\mu \mathrm{m}$ de comprimento, com valvas de 20-30 $\mu \mathrm{m}$ de espessura. Todas as valvas analisadas nesse nível são lisas; aparentemente nenhuma apresenta ornamentação. Sua classificação taxonômica, por conta da sua simplicidade morfológica, torna-se muito difícil. 


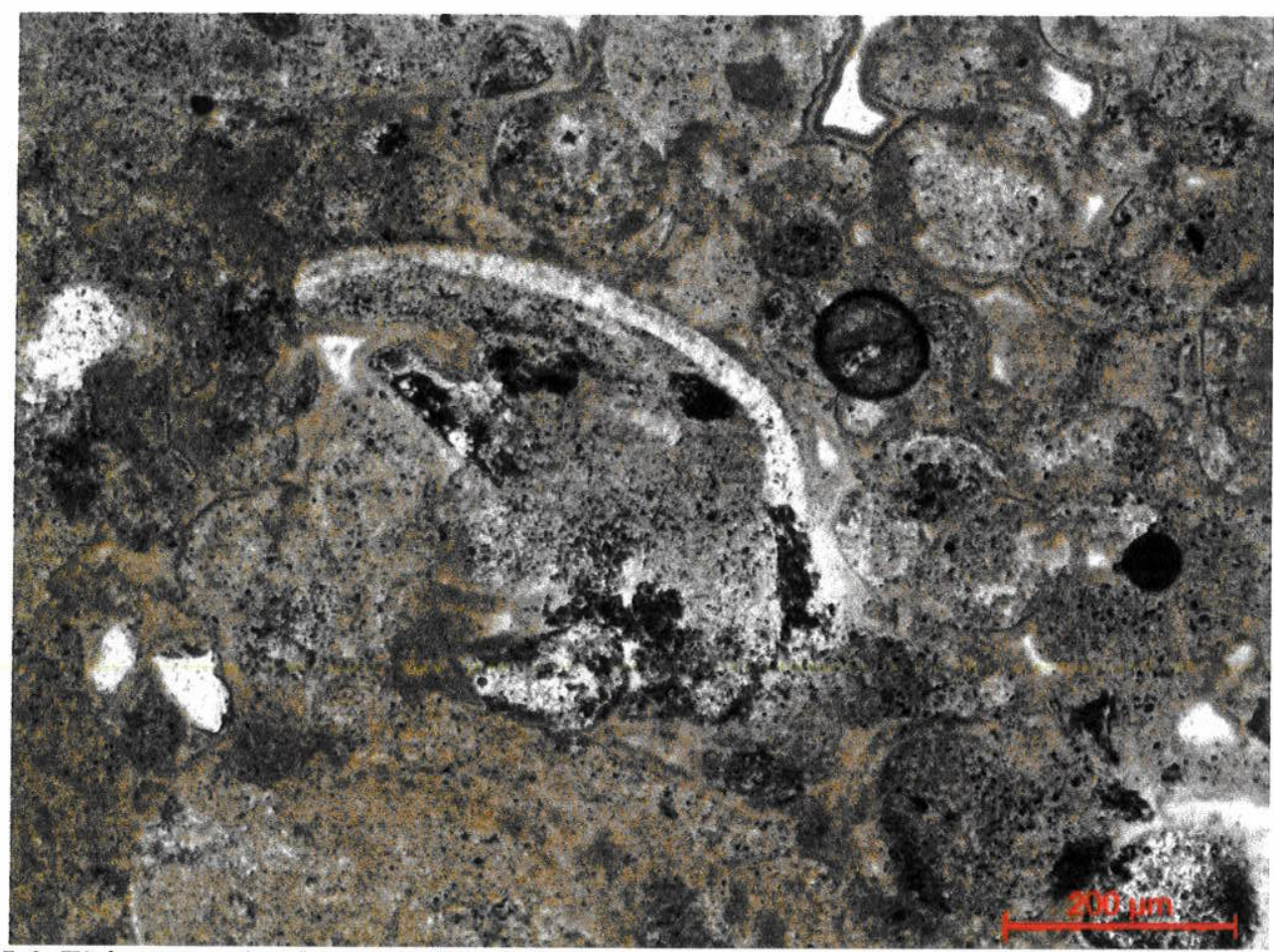

Figura 5.6: Típico exemplar de ostracode no Nível 1, representado por uma valva desarticulada substituída por sílica. Notar alteração na parte inferior da valva. A rocha que a contém aparenta ser um grainstone com ooides alterados.

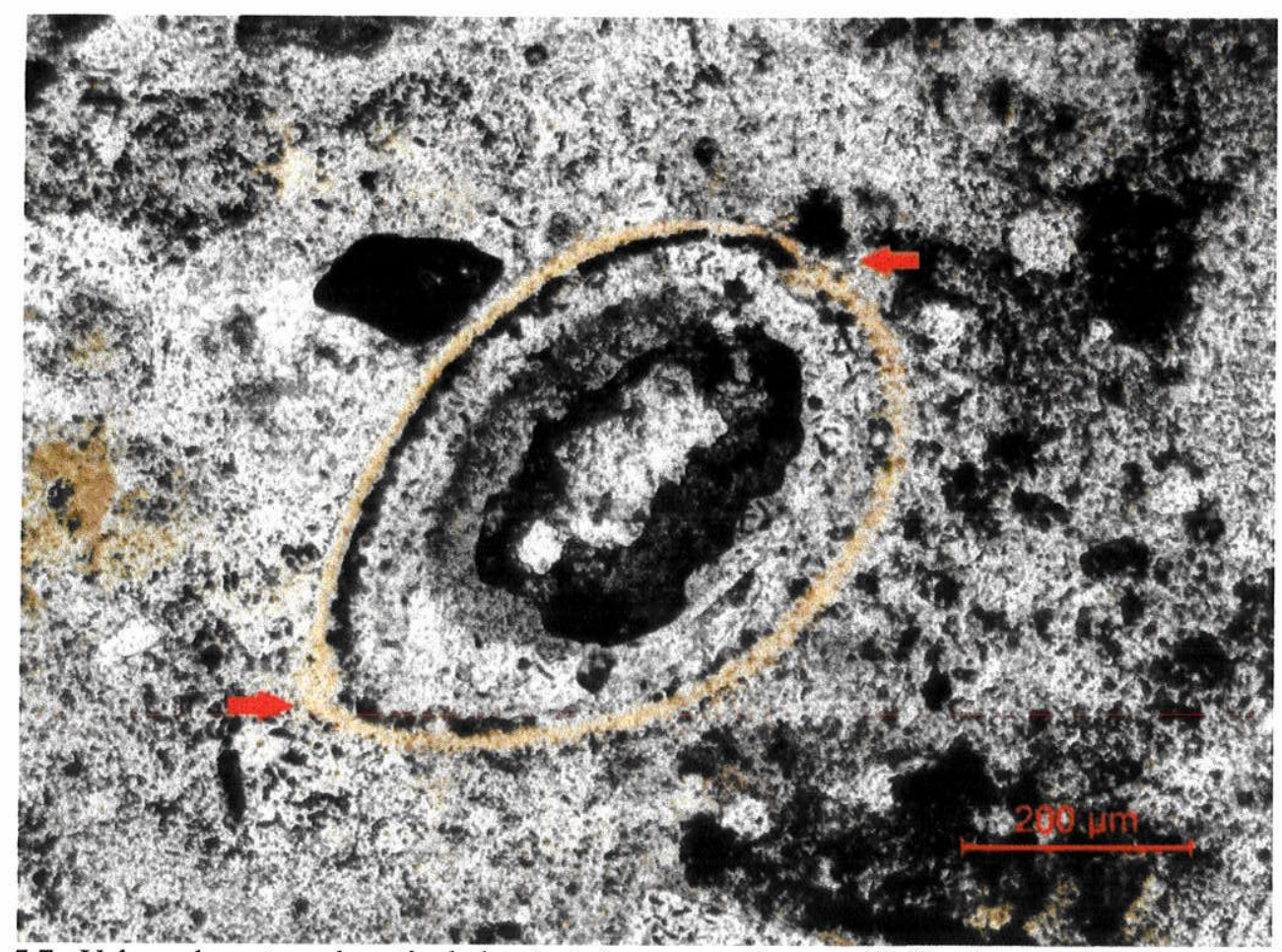

Figura 5.7: Valvas de ostracode articuladas (setas) num packstone silicificado e muito alterado (Nível 1). Valvas articuladas são raras nesse nível. O preenchimento centrípeto do interior do fóssil indica que o fóssil estava vazio quando da silicificação. O centro do espécime está oco. 
Oncoides ocorrem nesse nível mas são muito menos abundantes que as valvas de ostracodes (figura 5.8). Suas lâminas medem em torno de $400 \mu \mathrm{m}$ de espessura, e caracteristicamente são irregulares. Nota-se a presença de moldes de filamentos microbianos dentro das laminações (figura 5.9). Os oncoides não aparentam fragmentação, o que pode ser um indício de que se tratam de bioclastos autóctones e/ou de que o ambiente de deposição era de águas calmas.

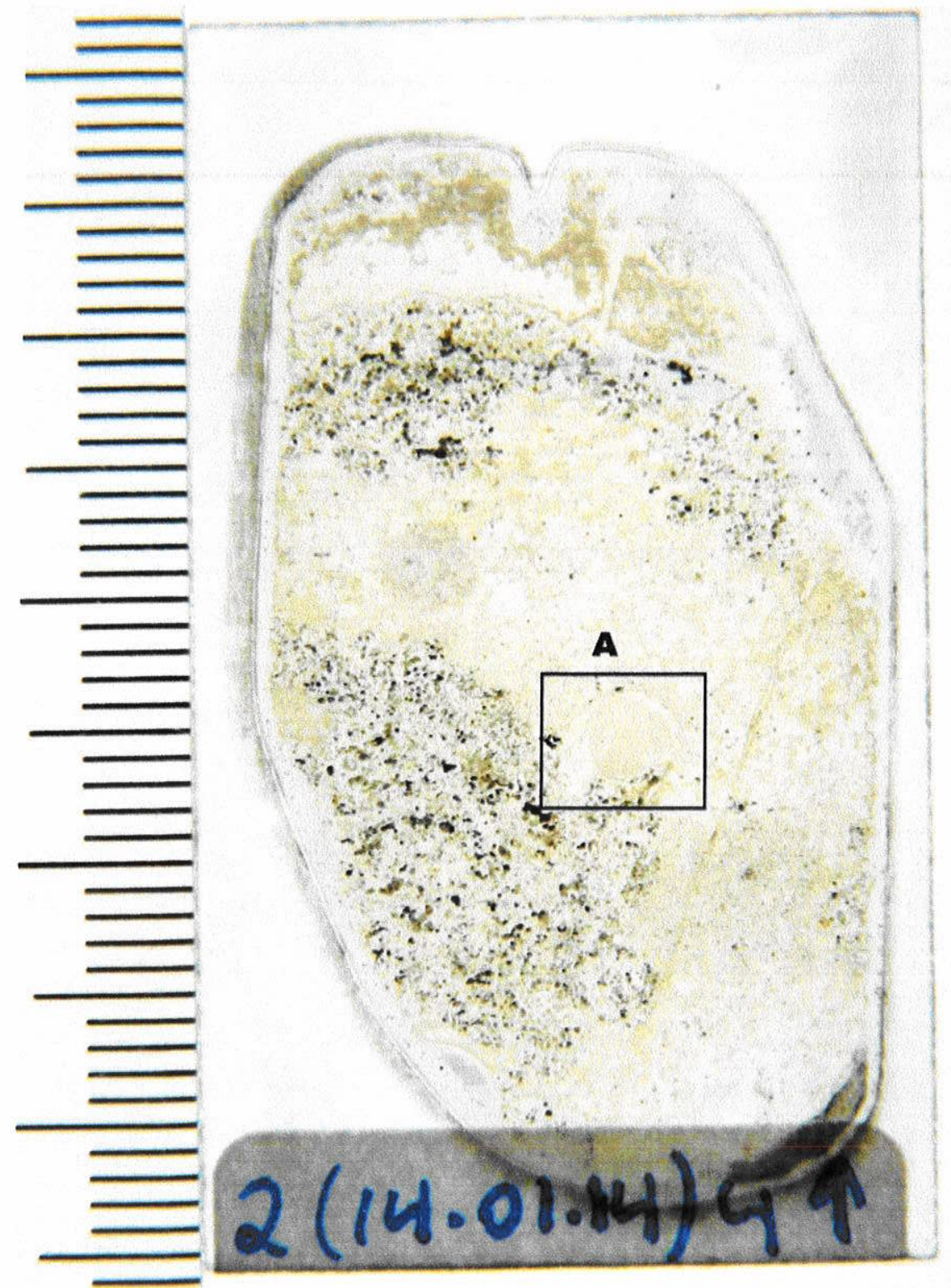

Figura 5.8: Lâmina petrográfica de rudstone oncolítico com o oncoide ilustrado na figura $\mathbf{5 . 6}$ indicado no retângulo (A). 


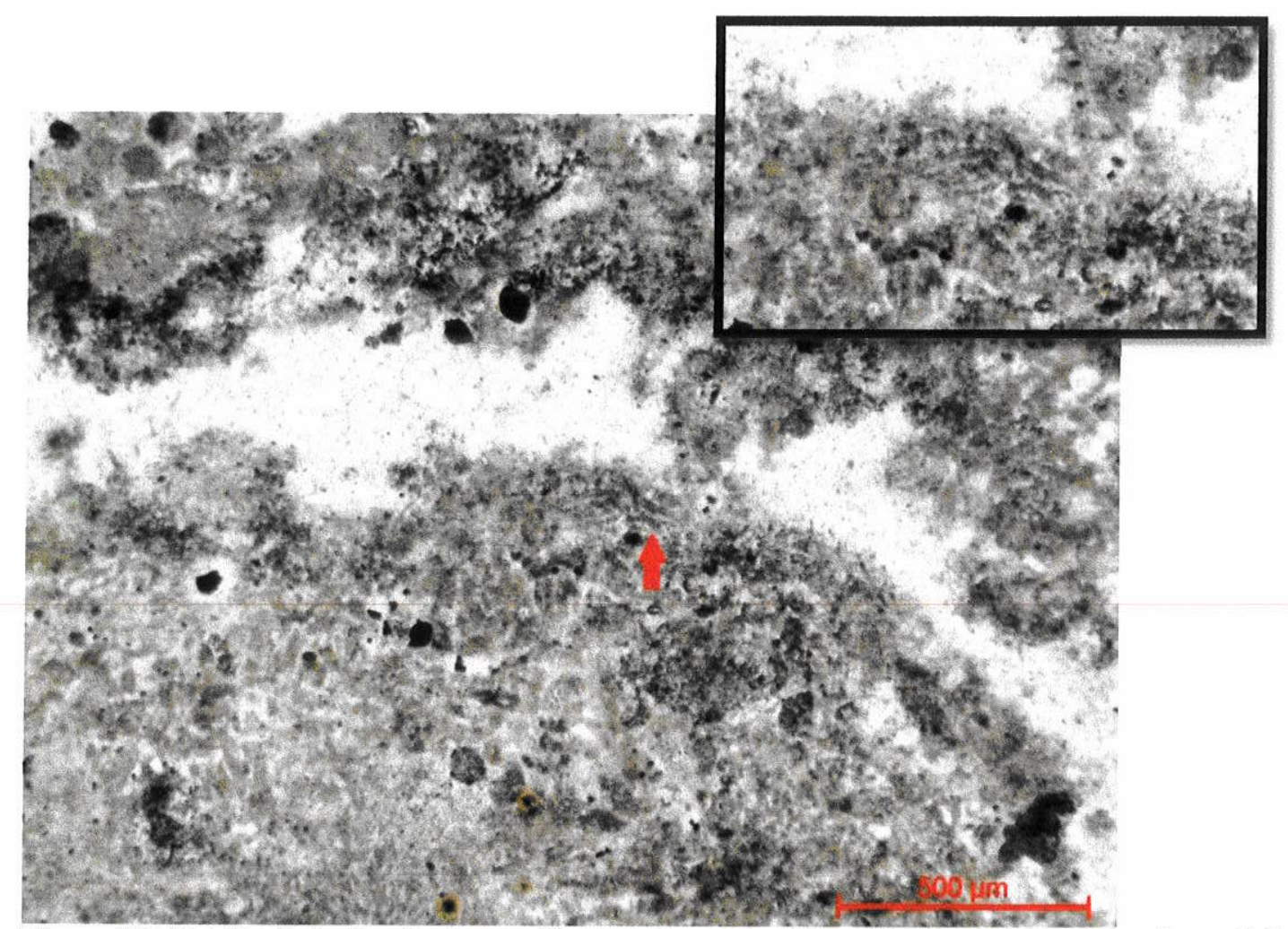

Figura 5.9: Detalhe da laminação do oncoide no rudstone oncolítico silicificado ilustrado na figura 5.5. A seta vermelha indica moldes de prováveis filamentos bacterianos, mostrados em detalhe na figura menor.

\subsection{Intervalo B e Nível 2}

O nível dos afloramentos lateralmente correlatos à base dos cones silicosos compreende o Intervalo B. O Nível 2 corresponde aos sedimentos depositados no nível da base dos cones, logo acima do Nível 1.

A sucessão consiste em camadas finas $(20-30 \mathrm{~cm}$, aproximadamente) de rochas presumivelmente carbonáticas e/ou siliciclásticas intensamente silicificadas, depositadas quando da ocorrência do evento hidrotermal da região. É difícil determinar com exatidão a natureza acerca dessas rochas, pois em geral elas se apresentam intensamente alteradas pela silicificação e "sujas", com cristais pequenos e opacos, aparentemente pirita. Aqui, como no Nível 1, o processo de silicificação parece ter ocorrido de maneira diferenciada. Uma feição típica são poros revestidos por uma ou duas finas películas ou camadas muito finas, uma mais clara que a outra. Contudo, nenhuma das duas exibe padrão cristalino interno, e sob nicóis cruzados, nenhuma das duas películas apresenta individualidade petrográfica. $\mathrm{O}$ que se vê, pois, é que fibras de calcedônia partem dos limites originais do alvéolo, atravessam as duas películas e continuam para dentro do alvéolo até encontrarem-se com outro leque fibrorradiado de calcedônia oriundo do lado oposto. 
Nas rochas presumivelmente carbonáticas, alguns corpos grandes e arredondados que lembram oncoides são observados, mas a preservação da laminação é insuficiente para corroborar definitivamente essa interpretação. Poderiam ser, talvez, pisoides da atividade hidrotermal. Todas as três lâminas examinadas deste nível apresentam estruturas (componentes) um tanto bizarros. Destaque seja dado às feições tubulares discordantes muito estranhas, curtas e isoladas em algumas áreas; em outras áreas são longas, paralelas, abundantes, algumas com ramificações curtas.

Os oncoides (figura 5.10) são encontrados em maior abundância do que nos outros estratos observados e foram identificados pela característica laminação interna irregular. Poucos microfósseis microbianos foram observados associados a estas estruturas. Um caso, no entanto, apresenta um agrupamento de microfósseis filamentosos razoavelmente bem preservados, evidentemente parte de um biofilme ou esteira microbiana, a julgar pela abundância e arranjo dos filamentos (figuras 5.11, 5.12 e 5.13). Estes microfósseis consistem de tubos cilíndricos, retos a ligeiramente curvos, sem(?) ramificação. Medem de 13-15 $\mu \mathrm{m}$ de diâmetro e os mais longos, quase paralelos ao plano da lâmina petrográfica, atingem $180 \mu \mathrm{m}$ de comprimento. Assim, os outros filamentos, que devem ser igualmente longos, parecem mais curtos ou fragmentados porque atravessam a espessura da lâmina petrográfica a ângulos mais altos. Não apresentam septos nem vestígios celulares internos (tricomas) e, por essas características, devem tratar-se de bainhas de microrganismos procarióticos, provavelmente cianobactérias. Neste caso, estes filamentos parecem ter sido preservados em uma região especifica de um oncoide num processo de rápida silicificação, evidentemente antes de serem decompostos. 


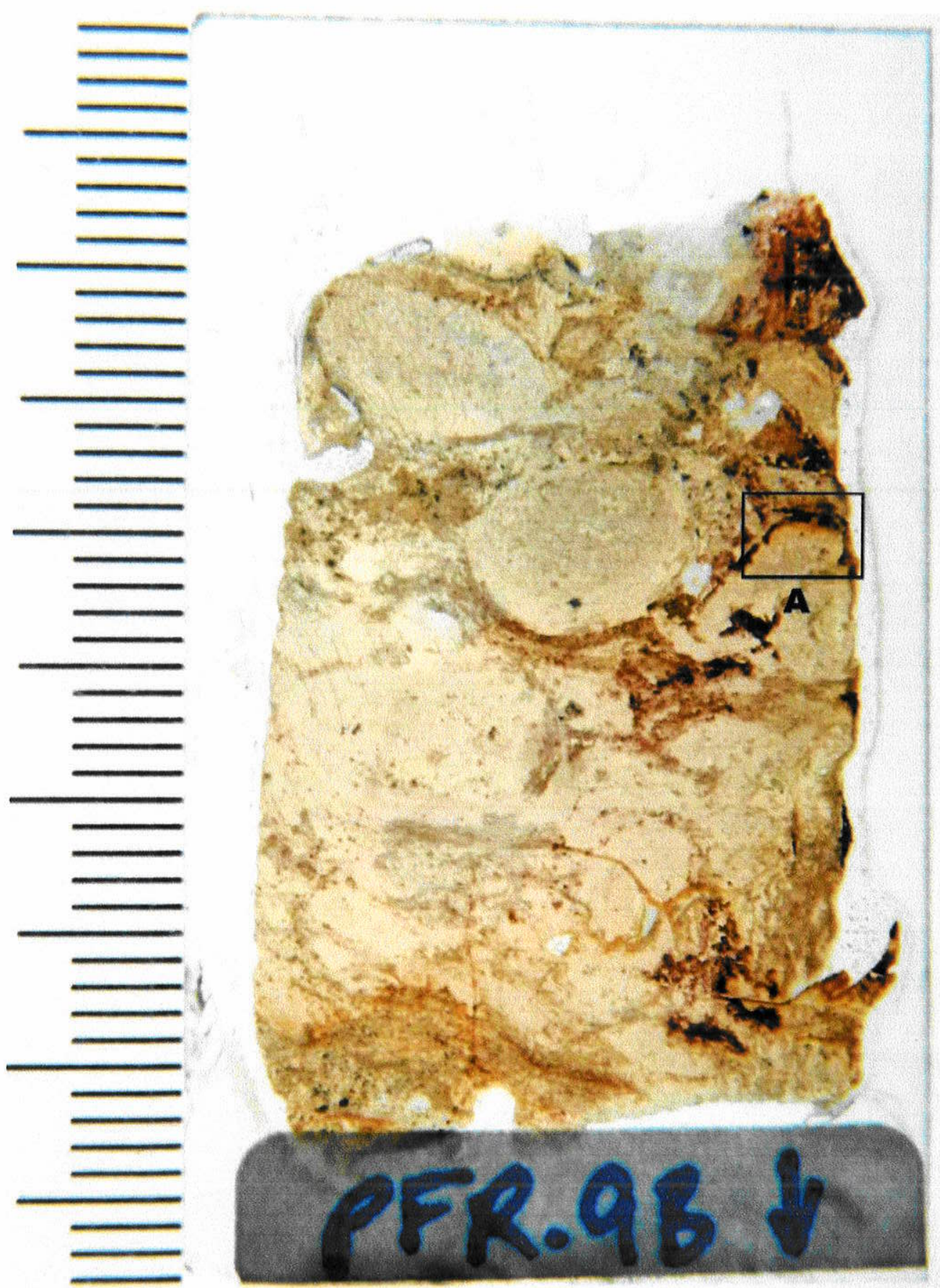

Figura 5.10: Lâmina petrográfica de rudstone oncolítico silicificado mostrando em (A) o oncoide com filamentos microbianos detalhados nas figuras 5.11 a 5.13 . 


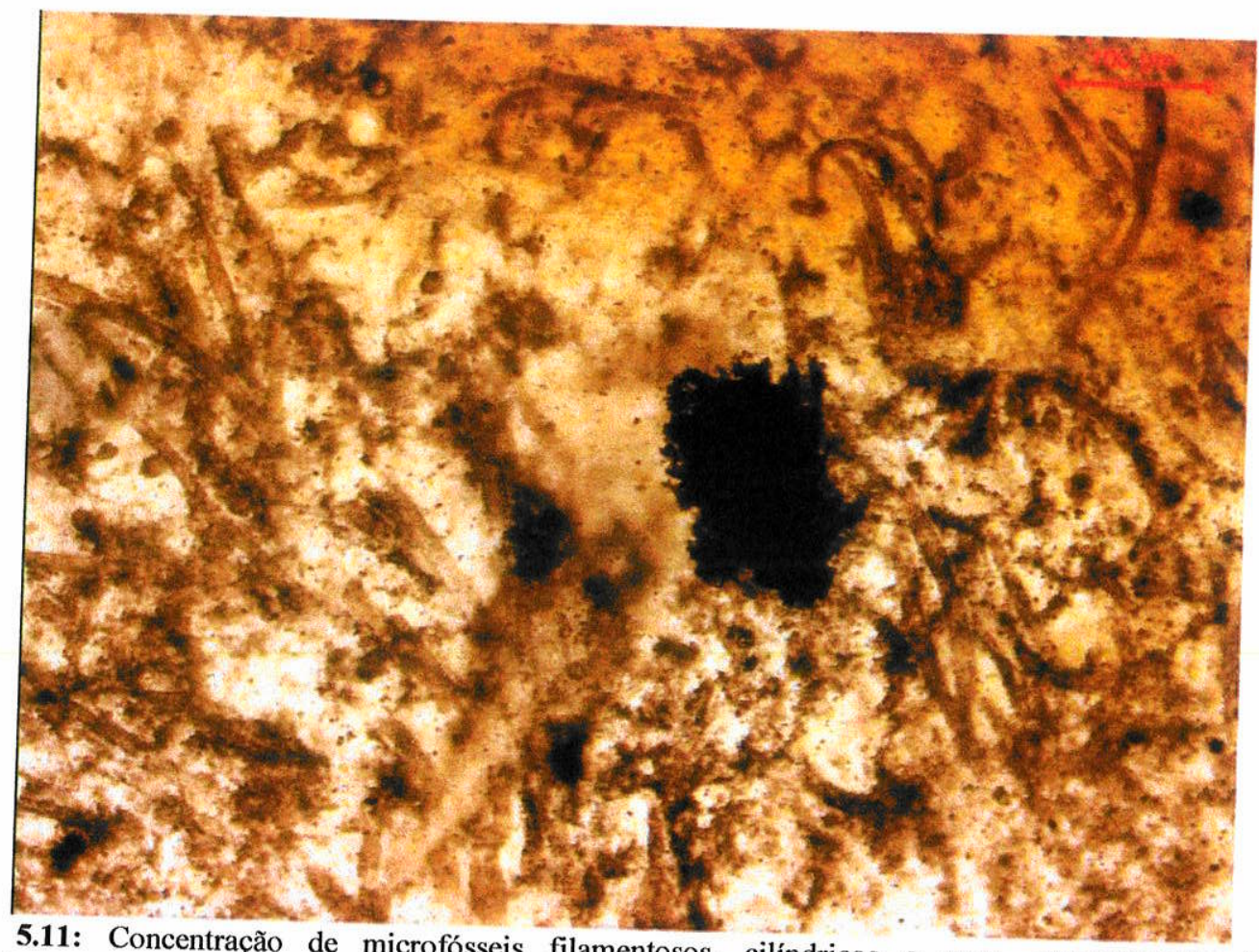

Figura 5.11: Concentração de microfósseis filamentosos, cilíndricos e ocos, aparentemente bainhas microbiana dentro do oncoide do privel 2 Ióticos, provavelmente cianobactérias, em biofilme ou esteira atravessa toda a espessura da lâmina petrográferalo B (ilustrado em figura 5.10). A maioria dos filamentos filamentos sobrepostos criam a ilusão de ramificação.

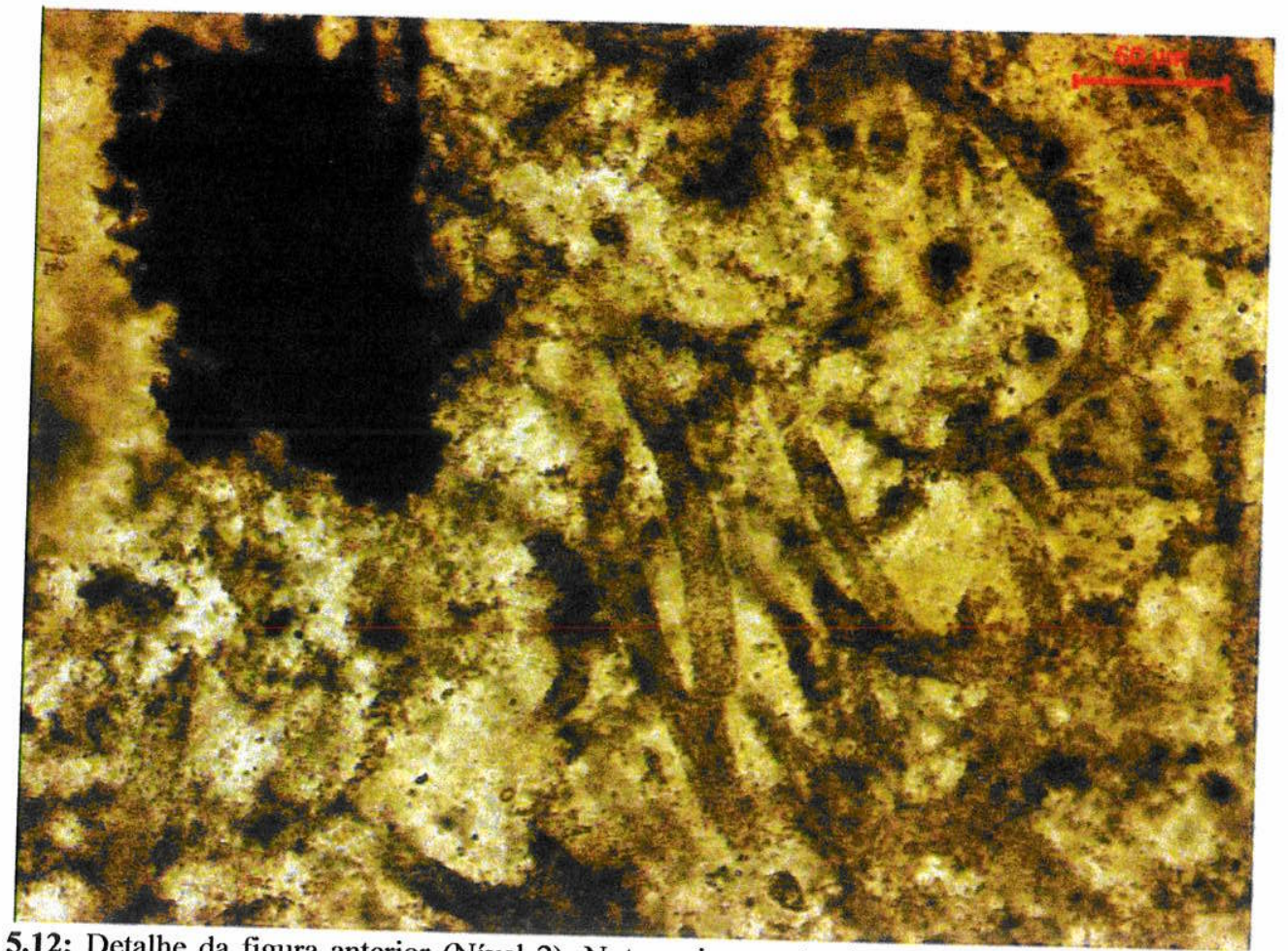

Figura 5.12: Detalhe da figura anterior (Nível 2). Notar a impressão de ramificação em filamento na porção média da figura dada por filamentos sobrepostos um ao outro. 


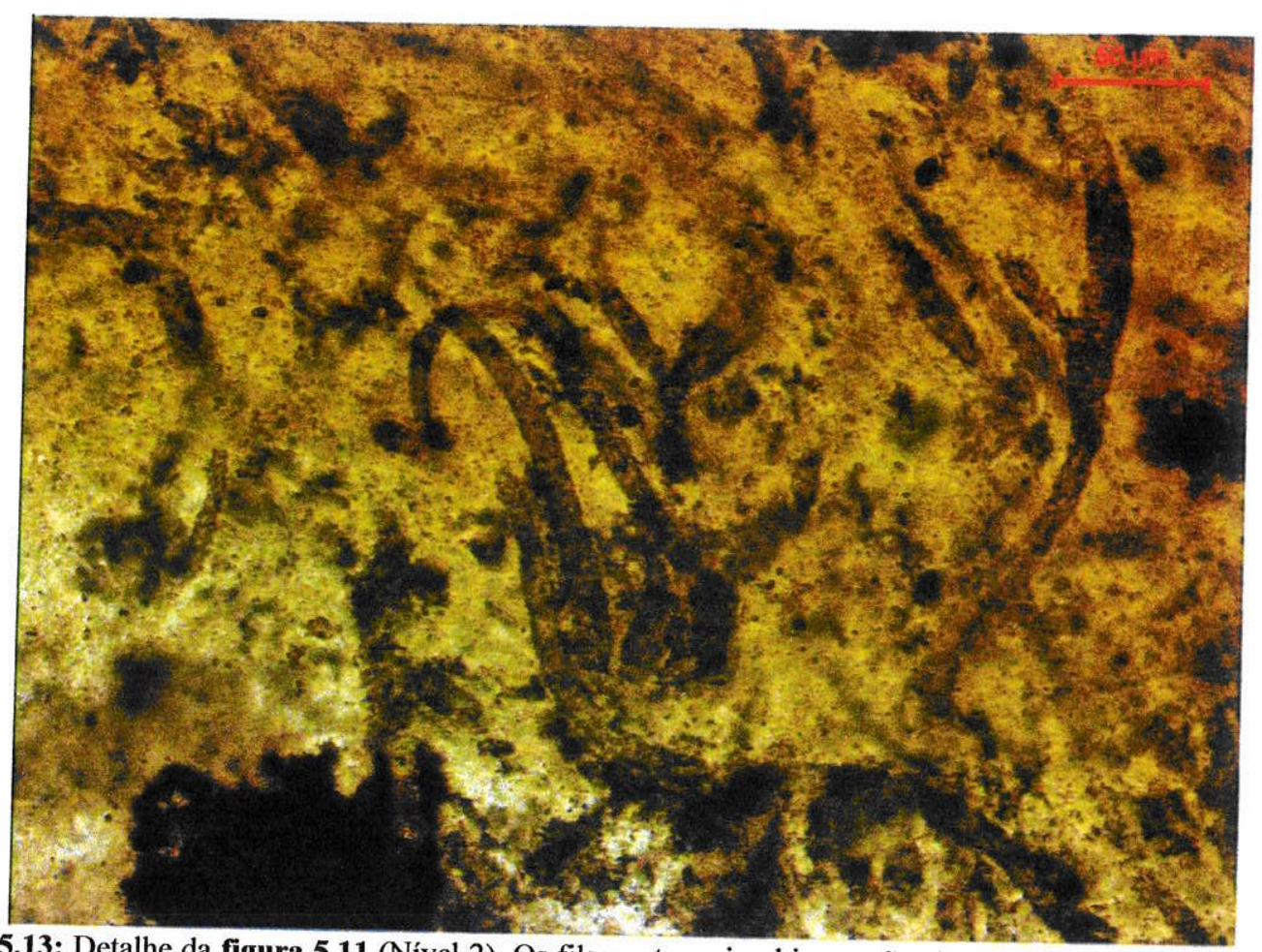

Figura 5.13: Detalhe da figura 5.11 (Nível 2). Os filamentos microbianos não são septados e não contêm restos de células internamente. Por isso, são interpretados como bainhas, originalmente mucilaginosas. Seu conteúdo celular original foi degradada antes da silicificação.

Os microfósseis filamentosos observados possuem morfologia condizente com cianobactérias formadoras de esteiras microbianas e provavelmente foram importantes na construção dos oncoides.

As valvas de ostracodes são similares às encontradas em carbonatos (grainstones) do Nível 1 (figuras 5.14, 5.15 e 5.16), mas sua abundância relativa decai bastante. Além disso, valvas articuladas são notoriamente raras. Assim como no Nível 1, seu grau de fragmentação torna-se difícil de caracterizar em seções delgadas como método de análise, e é ainda mais difícil neste nível pela má qualidade de preservação evidenciada pela pouca nitidez dos outros componentes e o aspecto "sujo" da sílica mencionado na descrição do Nível 1. Mesmo assim, o exemplar ilustrado em corte longitudinal na figura $\mathbf{5 . 1 6}$ apresenta forma elíptica mais alongada, semelhante ao contorno de valvas descritas na Formação Teresina, em Conchas (SP) não longe de Anhembi, por Sohn e Rocha-Campos (figs. 7.8 e 7.13, 1990) e identificados como Darwinula? e Gutschikia?, ambos gêneros não marinhos. 


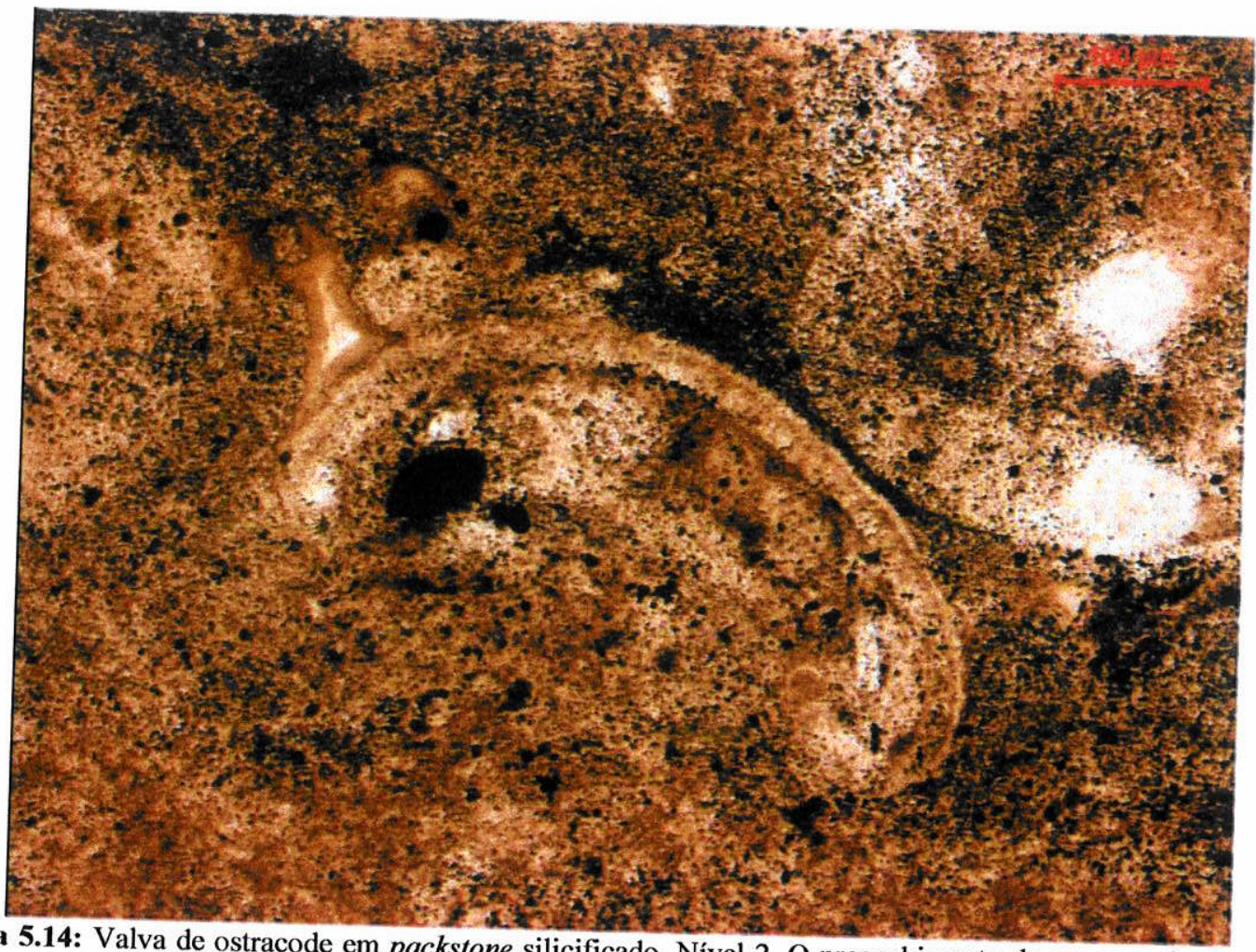

Figura 5.14: Valva de ostracode em packstone silicificado, Nível 2. O preenchimento de espaços abertos neste
nível tipicamente se iniou esquerda da valva) e completado uma ou duas películas isópacas claras ou escuras (como evidenciado logo à esquerda da valva) e completado posteriormente pelo crescimento de leques de calcedônia.

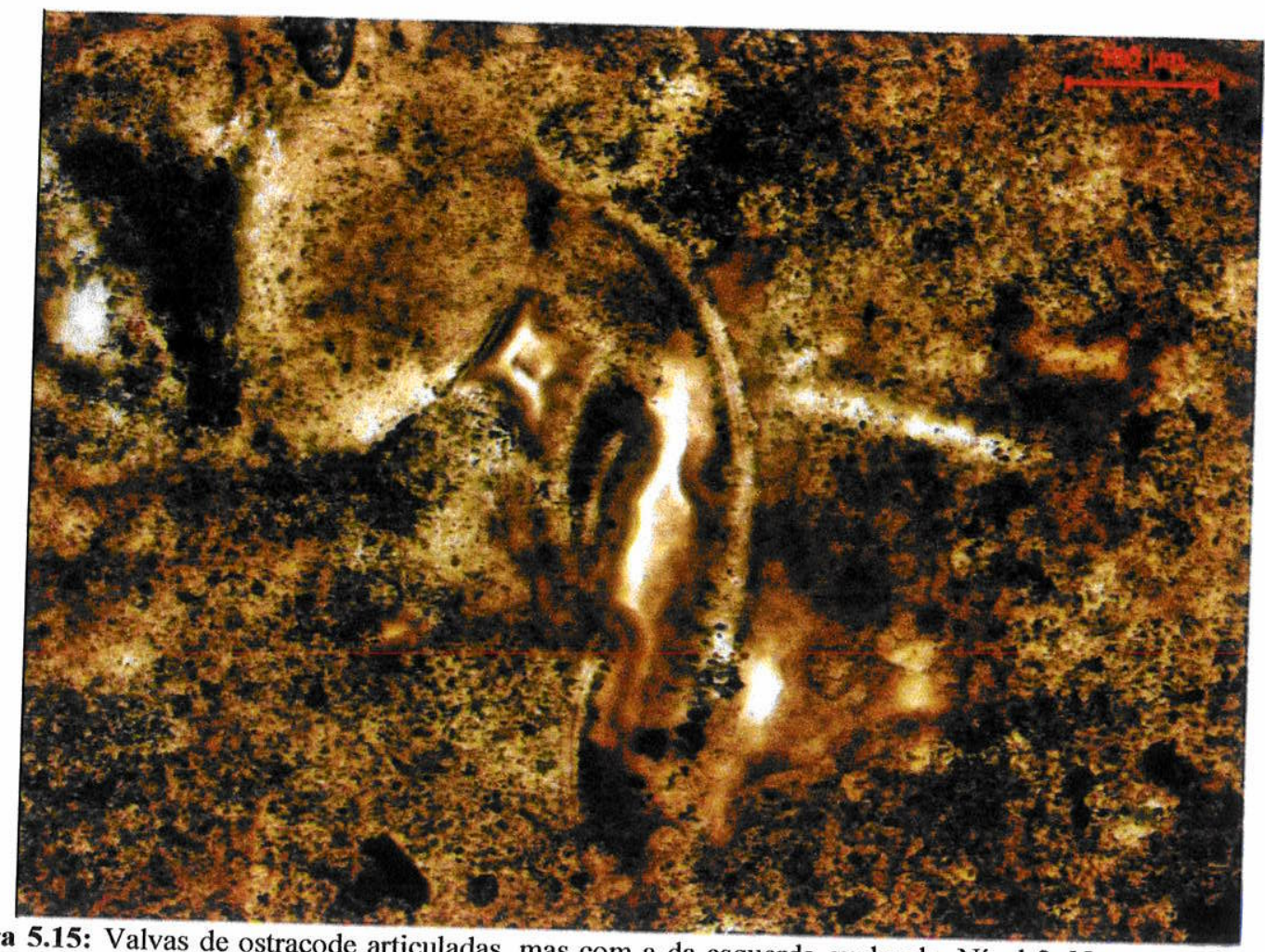

Figura 5.15: Valvas de ostracode articuladas, mas com a da esquerda quebrada, Nível 2. No centro da figura, ostracode. A má definição dos contornos deços abertos típico deste nível, aqui na parte interior das valvas de Nível 2. 


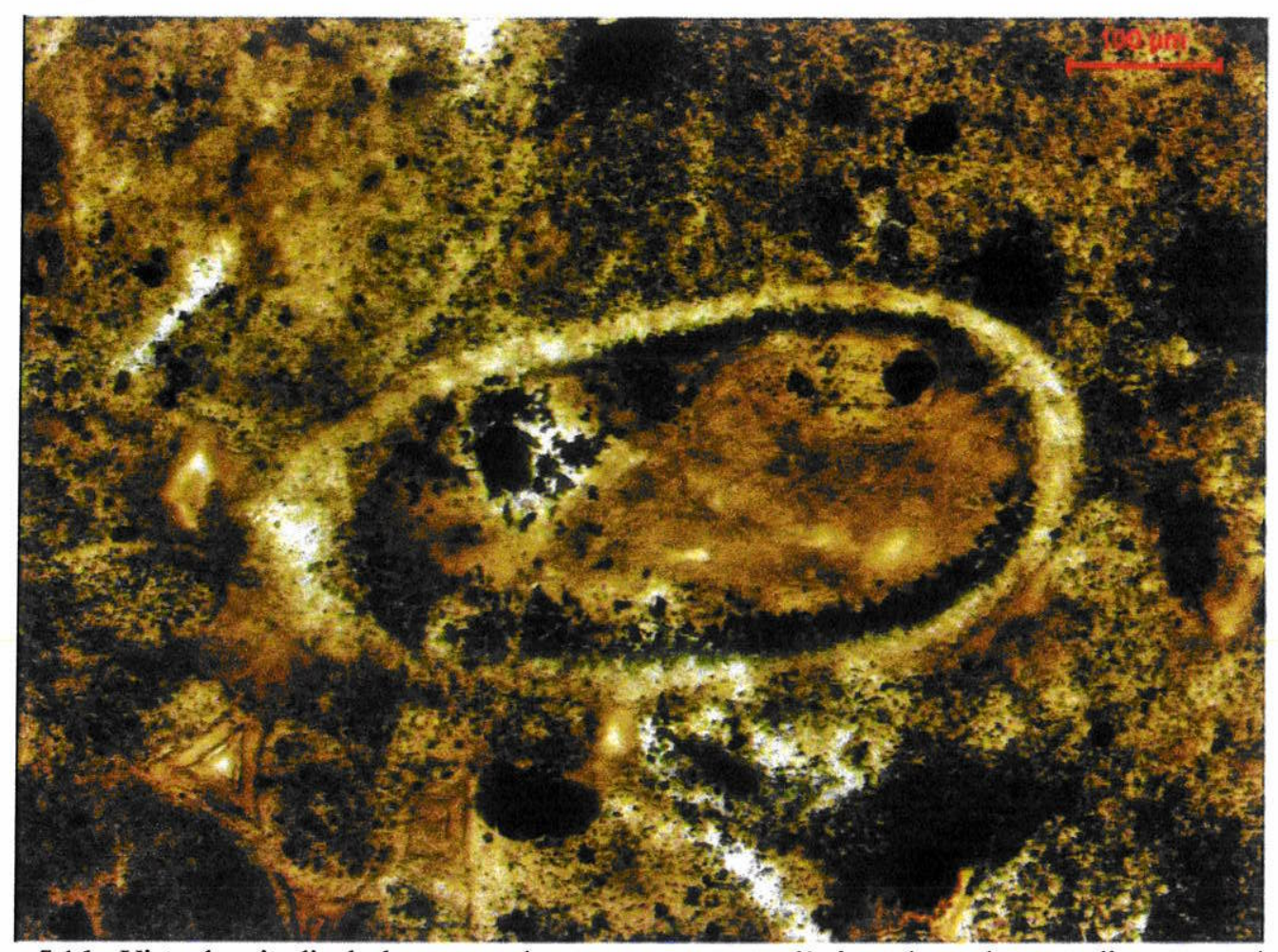

Figura 5.16: Vista longitudinal de uma valva com contorno elíptico alongado, semelhante a valvas de Darwinula? e Gutschikia? (ostracodes não marinhos) descritas na Formação Teresina, em Conchas (SP), por Sohn e Rocha-Campos (figs. 7.8 e 7.13, 1990). O revestimento da superficie interna da valva pelo mineral escuro (pirita) e sua ausência nas bordas do poro aberto entre grãos, à esquerda da valva, indicam que a pirita se formou no sedimento carbonático antes do evento de silicificação.

\subsection{Intervalo C e Nível 3}

Os estratos que afloram acima do topo dos cones são os correspondentes ao Intervalo C. O Nível 3 consiste nos estratos que se localizam a aproximadamente um metro acima dos cones silicosos. Os topos dos maiores cones aparentam estar pouco abaixo (a menos de um metro) do Nível 3. A sucessão é bastante variada, sendo que no Nível 3 é possível identificar intercalações de níveis carbonáticos fossilíferos com siliciclásticos (siltitos e arenitos).

A silicificação no Nível 3 difere claramente da dos níveis 1 e 2. Não existem túbulos, as rochas ainda preservam muito do carbonato original e os componentes são bem preservados; ou seja, a silicificação foi menos intensa. Não apresentam a mesma "sujeira" dos níveis inferiores. Observa-se substituição de partes do carbonato por microquartzo, quase criptocristalino, com textura microssacaroide, e preenchimento, por calcedônia fibrorradiada, de vazios previamente revestidos por cimento blocoso de calcita (figura 5.20).

Amostras dos carbonatos (mudstones(?), wackestones, grainstones, packstones, floatstones(?) e rudstones(?)) desse nível apresentam conteúdo fossilífero composto por conchas de moluscos bivalves, valvas de ostracodes e microbialitos (oncoides). 
As conchas de bivalves (figuras 5.17, 5.18 e 5.19) encontradas nesse nível são menores daquelas da coquina mais abaixo na sucessão do Intervalo A, mas bastante semelhantes àquelas observadas logo abaixo da ocorrência dos cones silicosos (Nível 1). Assim, só puderam ser observadas e propriamente analisadas à luz do microscópio petrográfico.

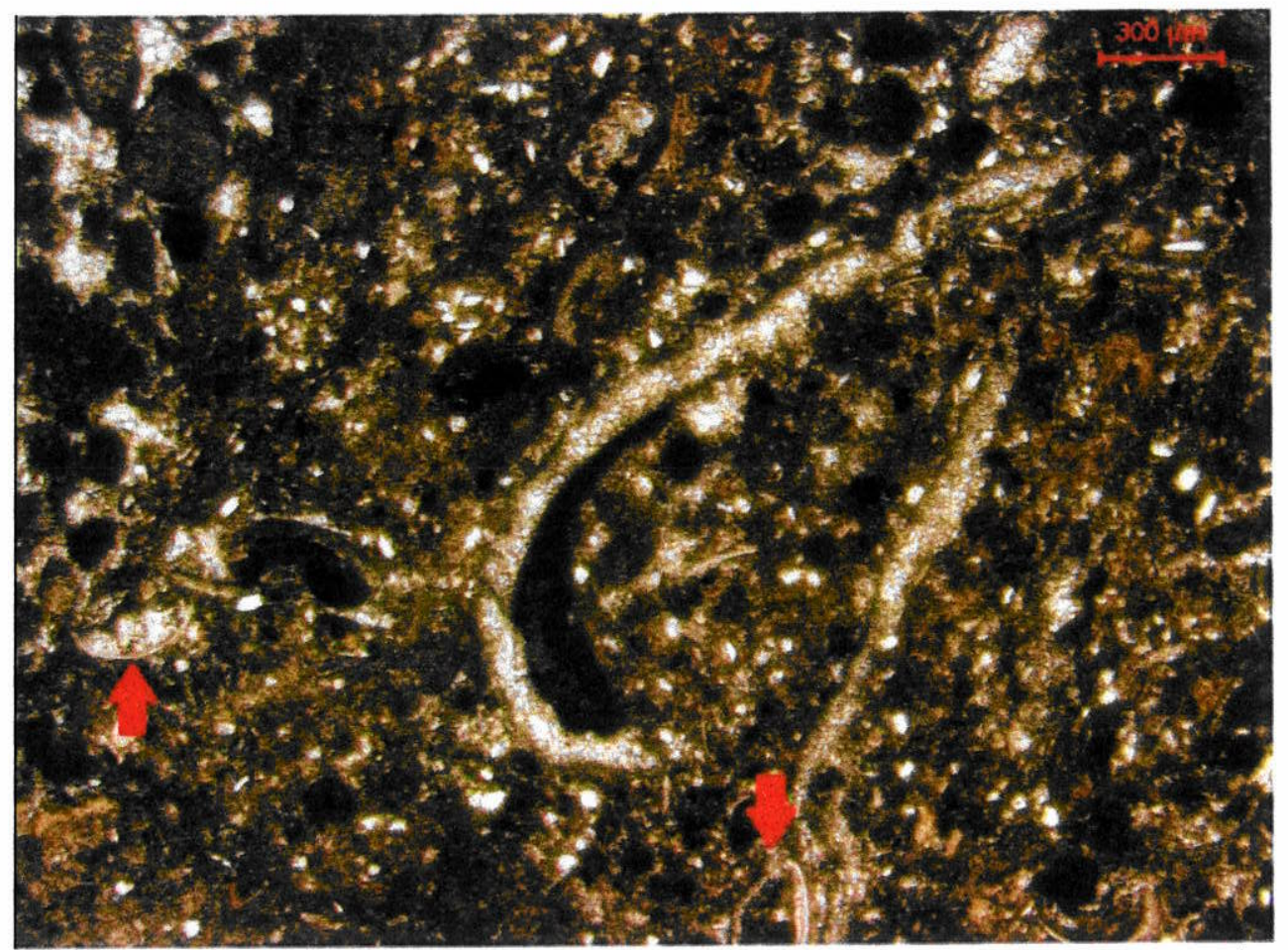

Figura 5.17: Conchas de moluscos bivalves desarticuladas em wackestone impuro (pequenos pontos brancos são grãos de quartzo do tamanho de silte), parcialmente silicificado, Nível 3. A irregularidade da superfície externa da concha curva representa possíveis linhas de crescimento). Notar o acúmulo de lama carbonática (micrita) em sua parte interna. Setas vermelhas apontam para valvas de ostracodes articuladas, ao centro, e desarticulada, à esquerda, ilustrando diretamente a diferença de tamanho entre esses bioclastos. 


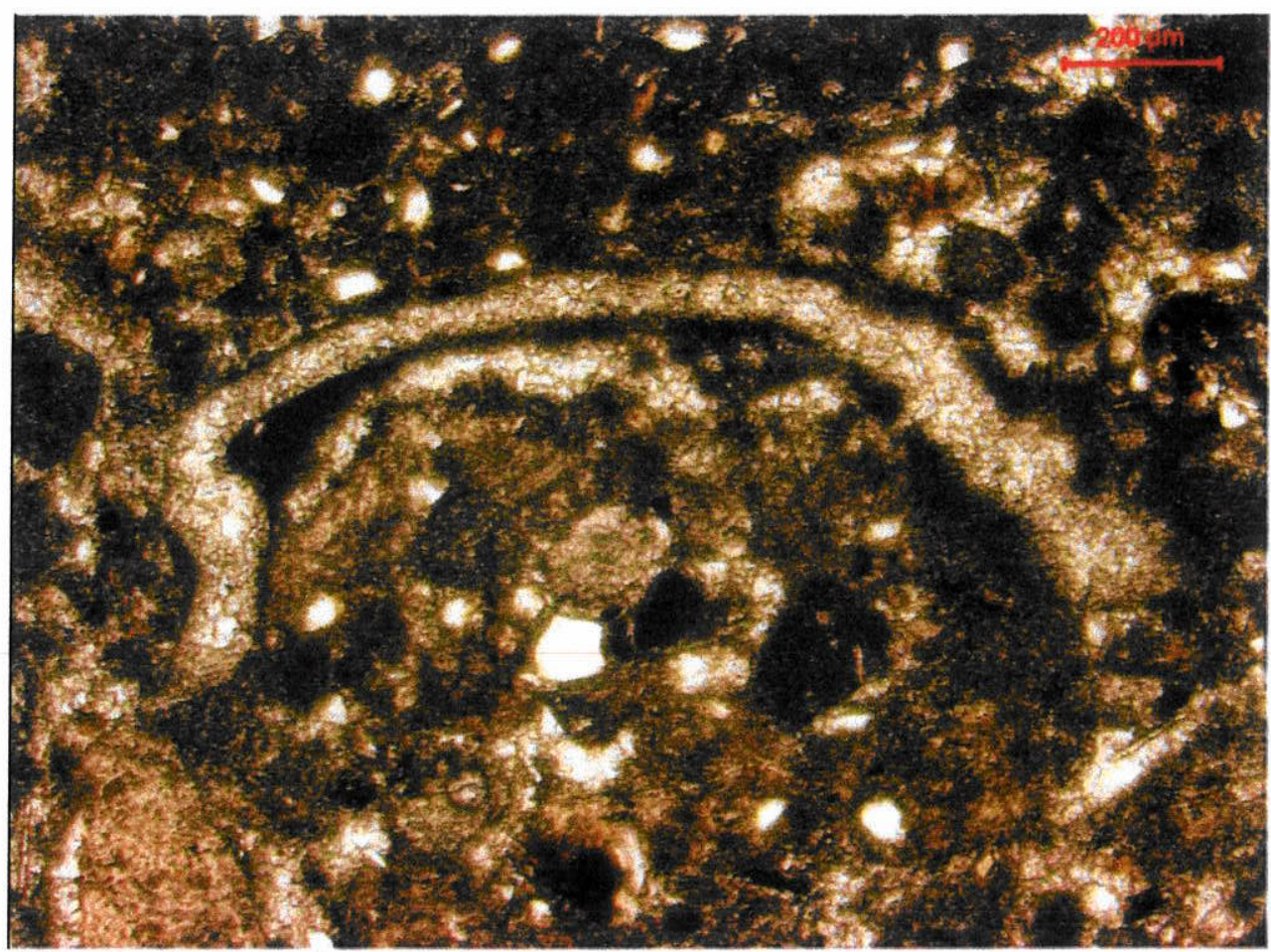

Figura 5.18: Concha de molusco bivalve desarticulada, presente num packstone impuro, parcialiñéfít silicificado, Nível 3. O formato desta valva, sem sinais de deformação, sugere que se trata de espécie diferente daquela ilustrada na figura anterior. A charneira teria sido do lado esquerdo. Este exemplar também apresenta sedimento interno micrítico.

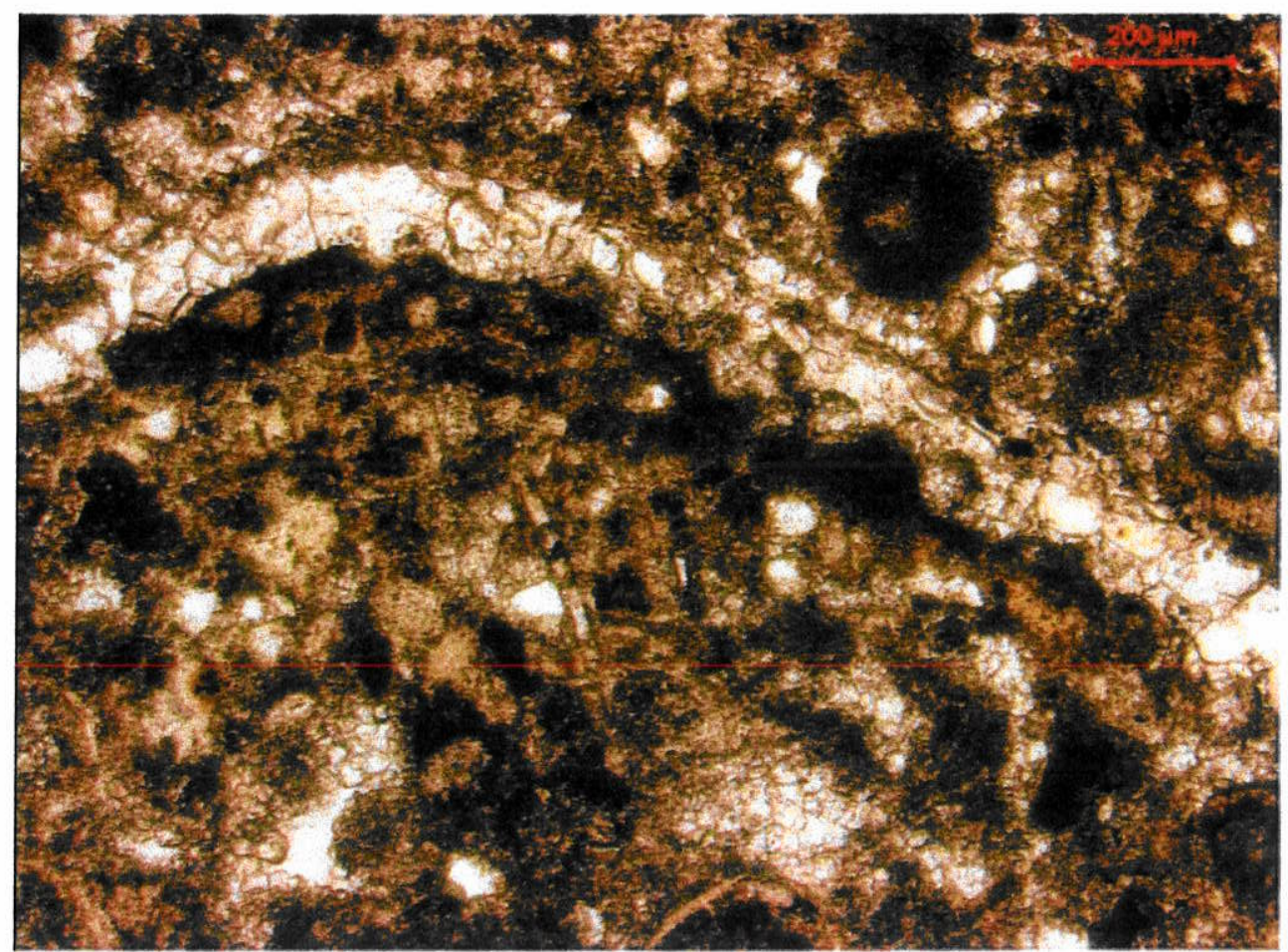

Figura 5.19: Concha de bivalve em grainstone impuro, parcialmente silicificado, Nível 3, também com sinais de revestimento micrítico de sua parte interna. A feição mais importante nesta imagem, porém, é o cimento de calcita de hábito blocoso que reveste o poro no canto esquerdo inferior, bem diferente do estilo de preenchimento dos poros nos Níveis 1 e 2 . 
As valvas de ostracodes são mais abundantes no Nível 3 do que no Nível 2, e em alguns casos, se apresentam articuladas (figuras 5.20, 5.21, 5.22 e 5.23). Essas valvas aparentam melhor preservação do que aquelas presentes no Nível 2.

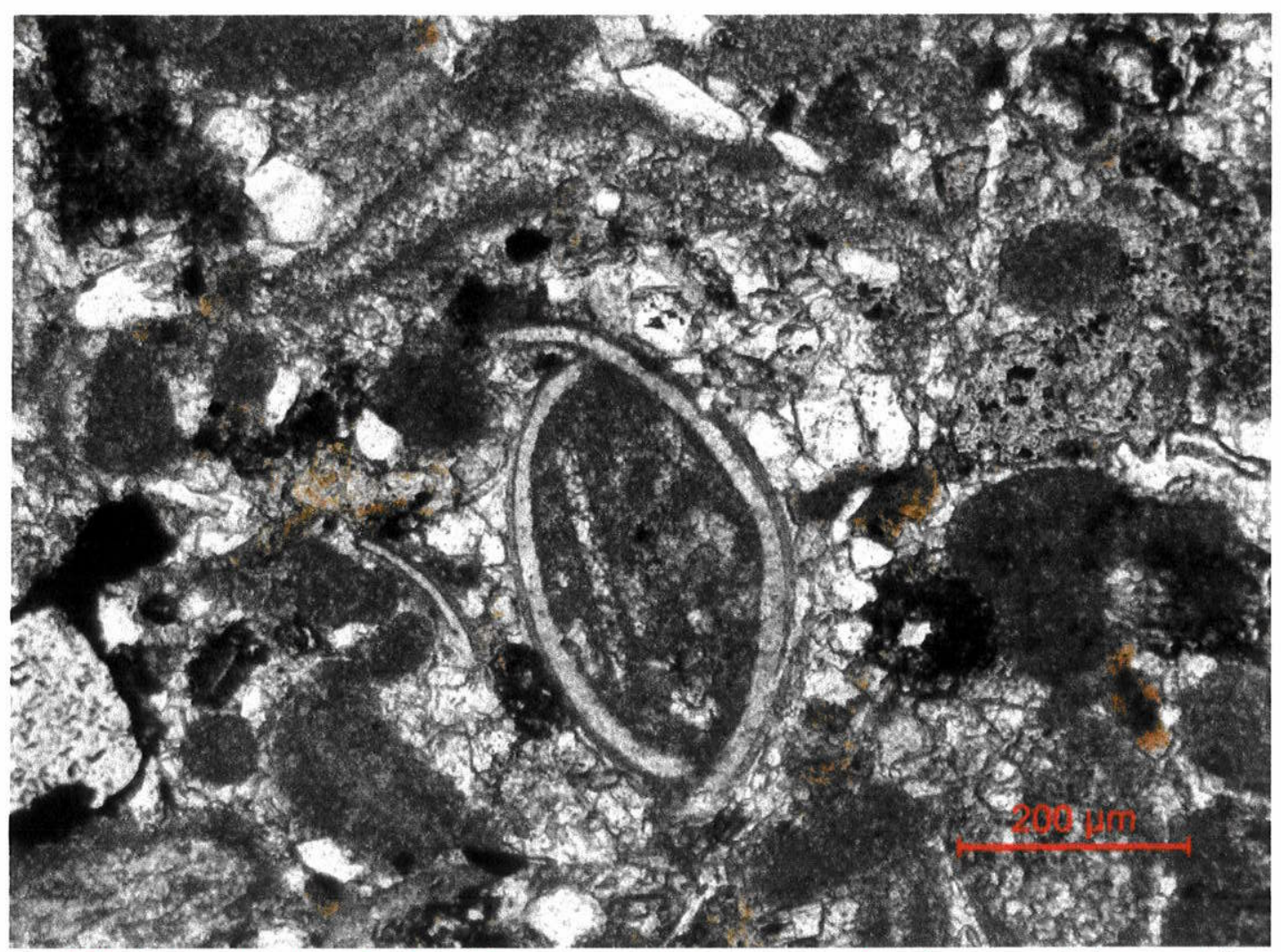

Figura 5.20: Valvas de ostracodes, Nível 3, em um grainstone impuro. As valvas preenchidos por sedimento óssilífero no centro da figura aparentam representar valvas de dois indivíduos diferentes, apesar de seu arranjo lembrar duas valvas articuladas. O bioclasto curvo pouco acima das valvas de ostracodes parece se tratar de um fragmento de uma concha de molusco bivalve, agora recristalizada.

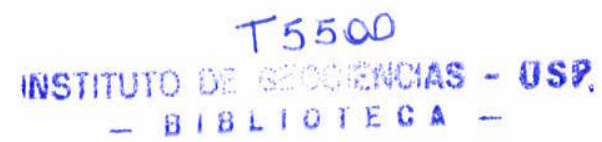




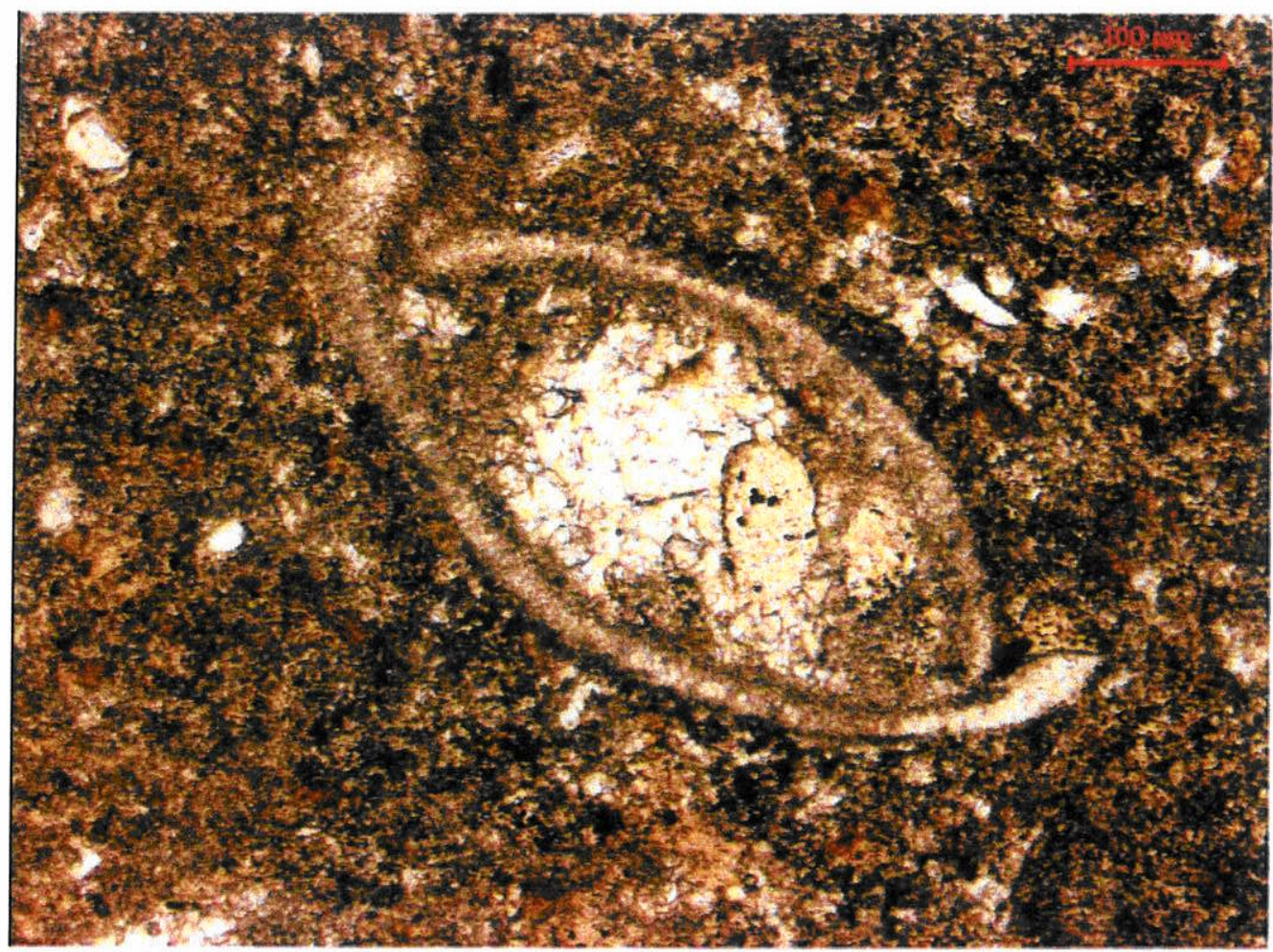

Figura 5.21: Valvas de ostracodes em wackestone, ou mudstone, parcialmente silicificado, Nível 3, parecidas com às vistas na Figura 5.20. Neste exemplo, porém, o fato das valvas abrigarem um espaço interno apenas parcialmente preenchido antes do soterramento final sugere a possibilidade delas representarem valvas articuladas mas ligeiramente deslocadas entre si. A estrutura prismática da concha é evidente na valva inferior, à esquerda.

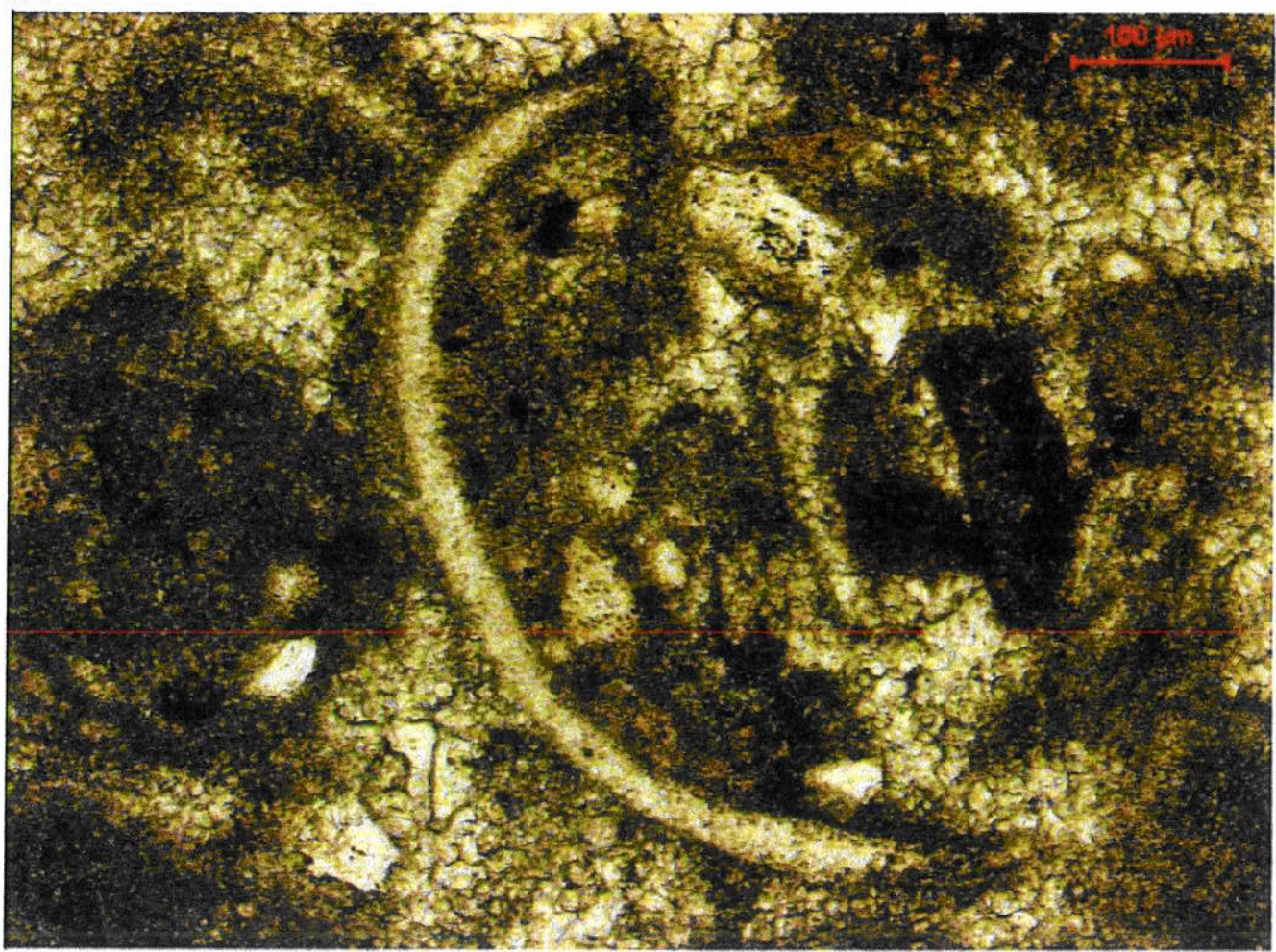

Figura 5.22: Valva desarticulada de ostracode em wackestone parcialmente silicificado em condição de preservação típica do Nível 3 e que também pôde ser observado nas figuras 5.20 e 5.21 . 


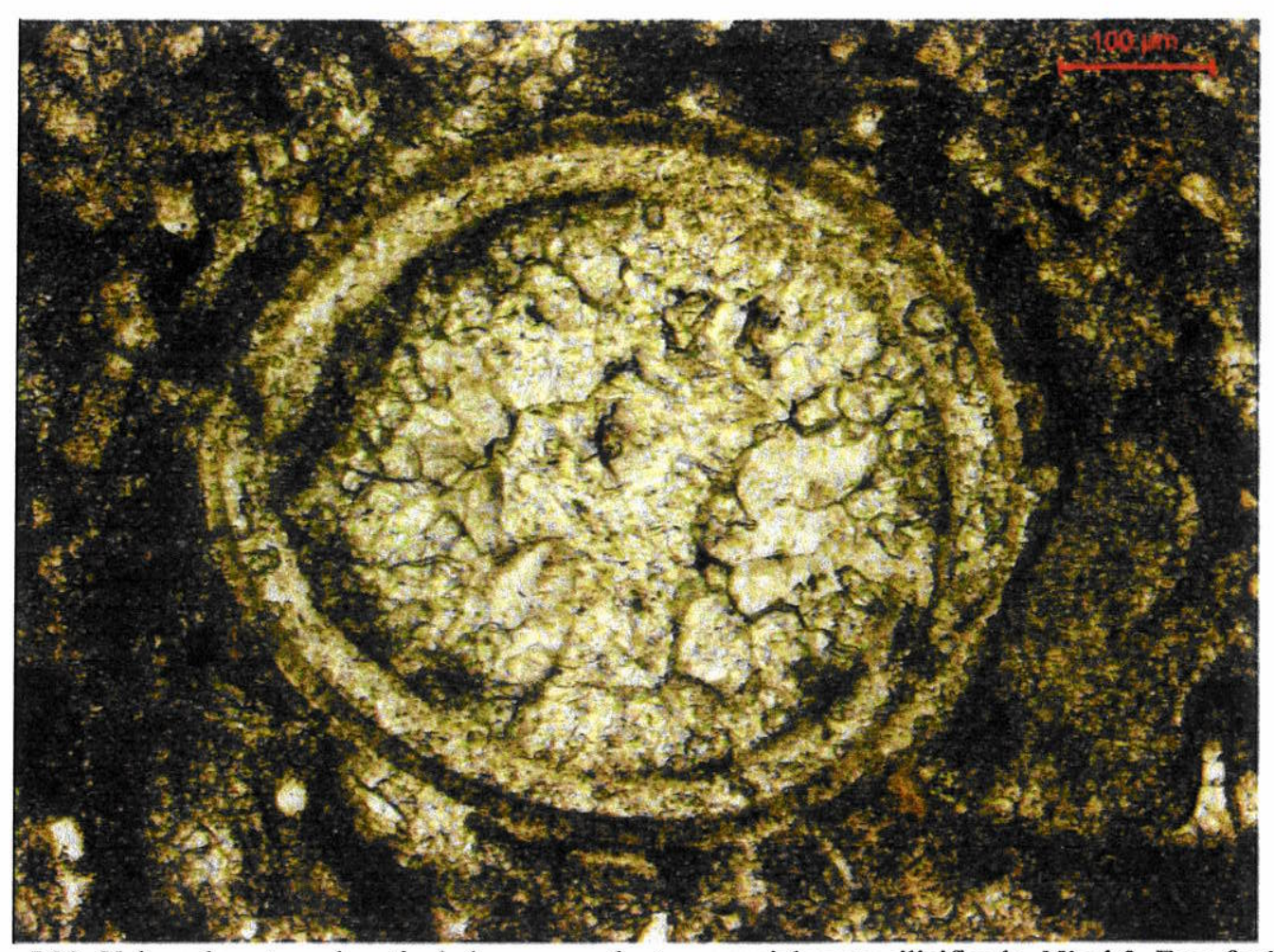

Figura 5.23: Valvas de ostracode articuladas em wackestone parcialmente silicificado, Nível 3. Esse fenômeno ocorre de maneira mais frequente do que nos níveis 1 e 2 . Este exemplar não apresenta silicificação. $O$ espaço interno entre as valvas foi preenchido por uma quantidade mínima de micrita e, posteriormente, por crescimento de calcita de hábito blocoso.

US oncoiđes encontrados nesse nível são maiores do que aqueles encontrados nos níveis 1 e 2 . Foram identificados três, não fragmentados, com pouco mais que $2 \mathrm{~cm}$ de diâmetro (figuras 5.24, 5.25 e 5.26). Apresentam forma basicamente circular a elipsoide com coloração rosada acinzentada. Sua laminação irregular é concêntrica com lâminas de cerca de 200-300 $\mu \mathrm{m}$ de espessura sem aparentes descontinuidades erosivas internas, mas com pelo menos um caso de fragmentação. Apresentam alguns filamentos microbianos, provavelmente moldes, mas mal preservados, em sua estrutura interna. Esses oncoides ocorrem em rochas carbonáticas (rudstone ou floatstone) juntamente com fragmentos de conchas de bivalves e valvas de ostracodes. 


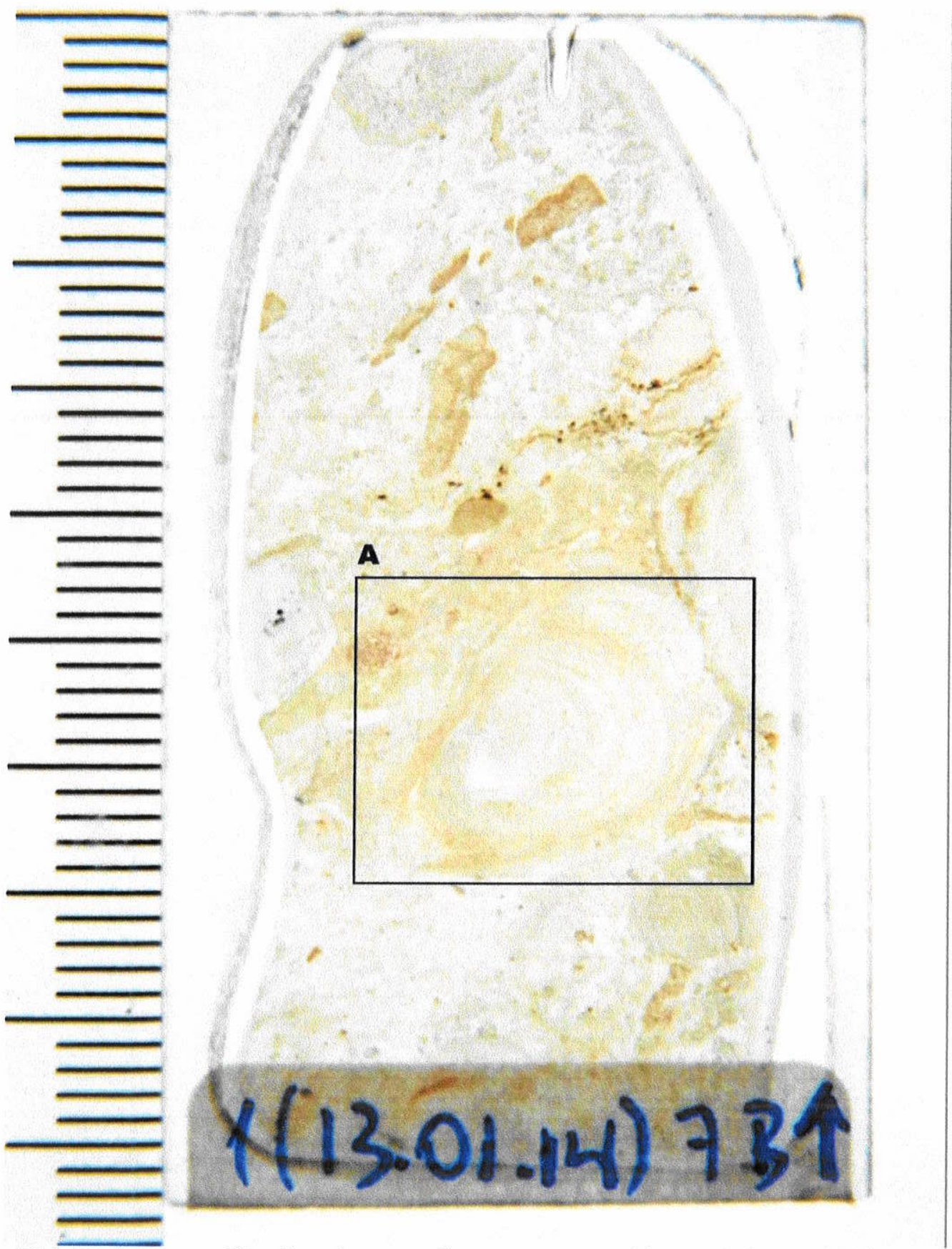

Figura 5.24: Lâmina petrográfica de rudstone ou floatstone com oncoides, parcialmente silicificado, Nível 3 . Em (A) é mostrado o oncoide detalhado nas figuras 5.25 e 5.26. 


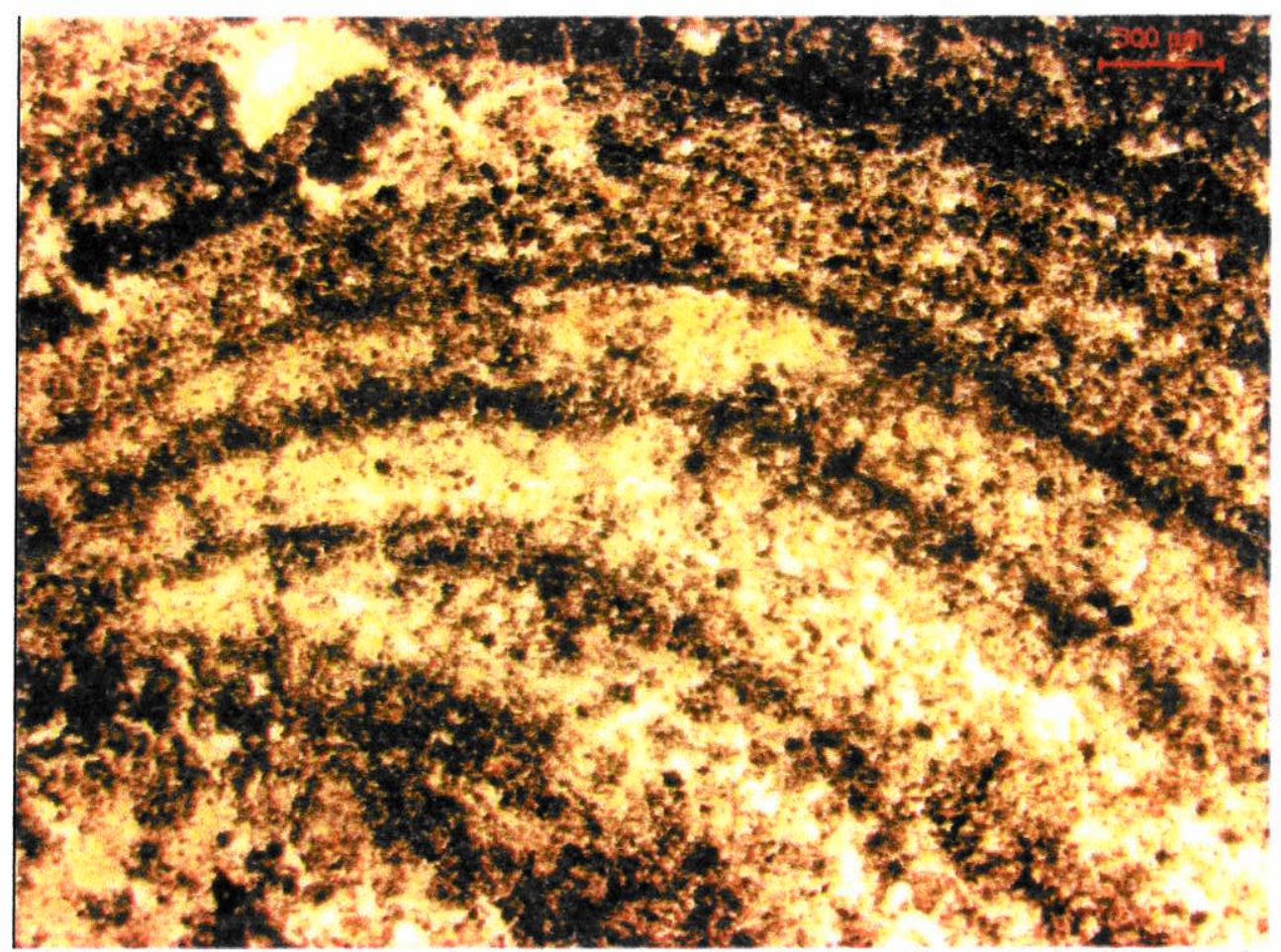

Figura 5.25: Laminação do oncoide assinalado na figura 5.24. Notar a alternação das diferentes bandas, de aparência mais regular, mas que, em detalhe, revelam irregularidades e prováveis filamentos microbianos (figura 5.26).

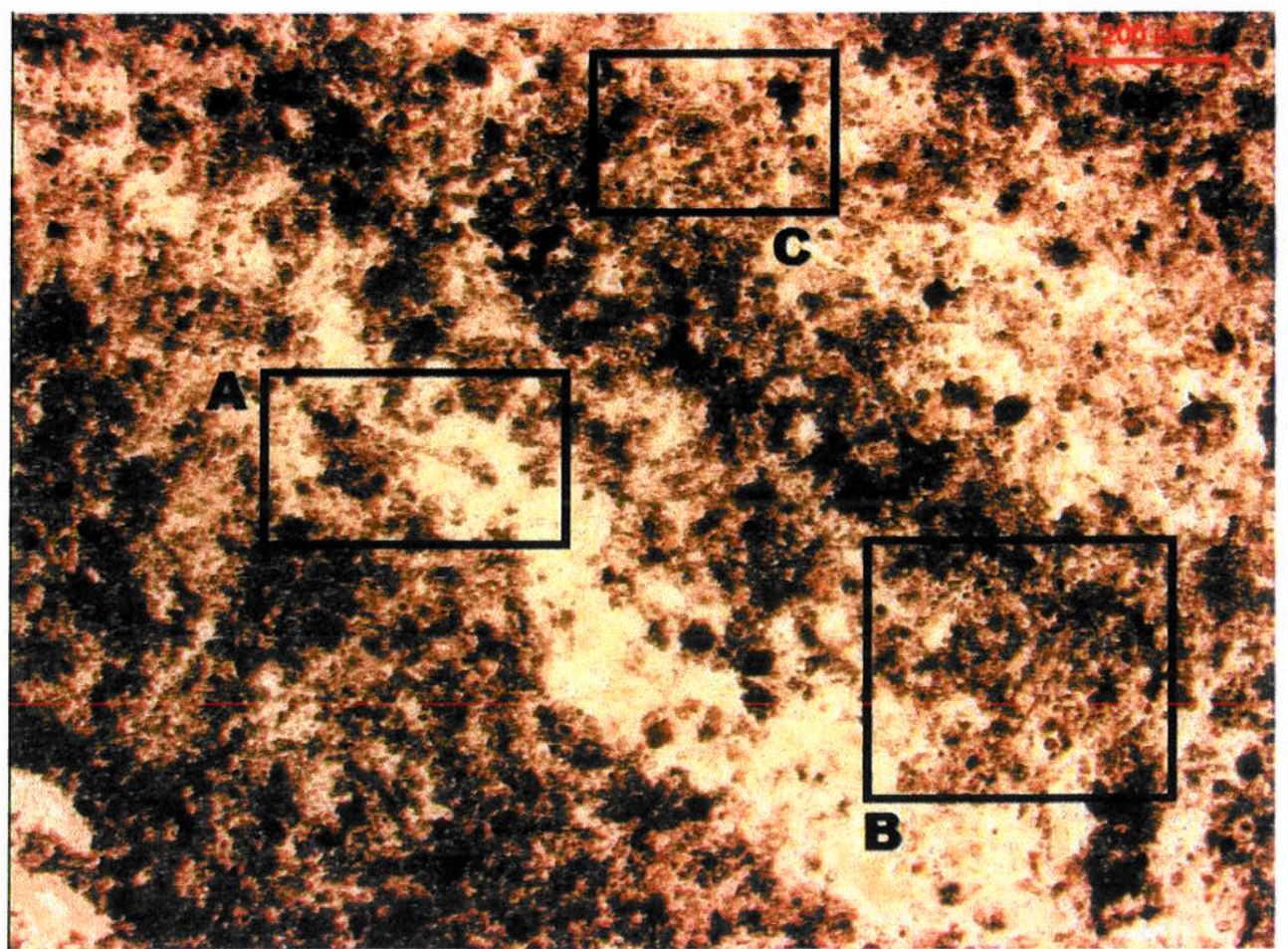

Figura 5.26: Detalhe da laminação microbiana do oncoide ilustrado na figura anterior (Nível 3). Filamentos microbianos fragmentados e mal preservados são indicados pelos retângulos (A), (B) e (C). 


\section{DISCUSSÃO}

A interpretação dos cones silicosos de Anhembi (SP) segue a proposta de Yamamoto et al. (2005) de que se tratam de estruturas formadas a partir de um evento hidrotermal ocorrido na região. Assim, as hipóteses para estas estruturas e para seu ambiente de deposição propostas por Yamamoto et al. (2005) são consideradas aqui como: (1) que se tratam de depósitos hidrotermais formados singeneticamente com as rochas lateralmente contínuas às suas bases, o que implica que esses estratos sejam penecontemporâneos a pelo menos parte do evento hidrotermal; (2) os estratos imediatamente abaixo dessas estruturas já estariam litificados, pelo menos incipientemente, quando da ocorrência do evento hidrotermal, e que seriam estes sedimentos e os sedimentos contemporâneos ao hidrotermalismo mais próximos dos cones que seriam mais afetados silicificação decorrente do evento e (3) que os estratos que ocorrem no Nível 3 teriam sido depositados somente após o término do evento, o que seria representado tanto pelo grau de silicificação das rochas desse intervalo como pela biota fóssil encontrada.

Em comparação com outros ambientes hidrotermais, o caso de Anhembi mostra-se único, primeiro, por exibir apenas um morfotipo dos depósitos; segundo, pela grande concentração de corpos em área muito pequena $\left(1,5 \mathrm{~km}^{2}\right)$; e, terceiro, por representar, aparentemente, um exemplo de hidrotermalismo subaquático.

A morfologia dos depósitos silicosos em Anhembi encontra correspondência na proposta de Guidry e Chafetz (2003) baseado no hidrotermalismo evidente em Yellowstone (EUA). Segundo eles, as estruturas de Anhembi seriam classificados como cones. Em Yellowstone, recebem este nome estruturas com morfologia cônica e estreita, com alto relevo e um canal (vent) central (figura 6.1 - A). Diferem dos montes dômicos (figura 6.1 - B), por não apresentar um reservatório ( $\mathrm{pool}$ ) terminal de água quente logo acima do canal, estrutura presente também nos outros dois morfotipos analisados por Guidry e Chafetz montes com terraços (terraced mounds, figura 6.1 - C) e lagoas (ponds, figura 6.1 - D), e por não estarem associados a depósitos formados por canais de descarga de água em ambiente subaéreo. 

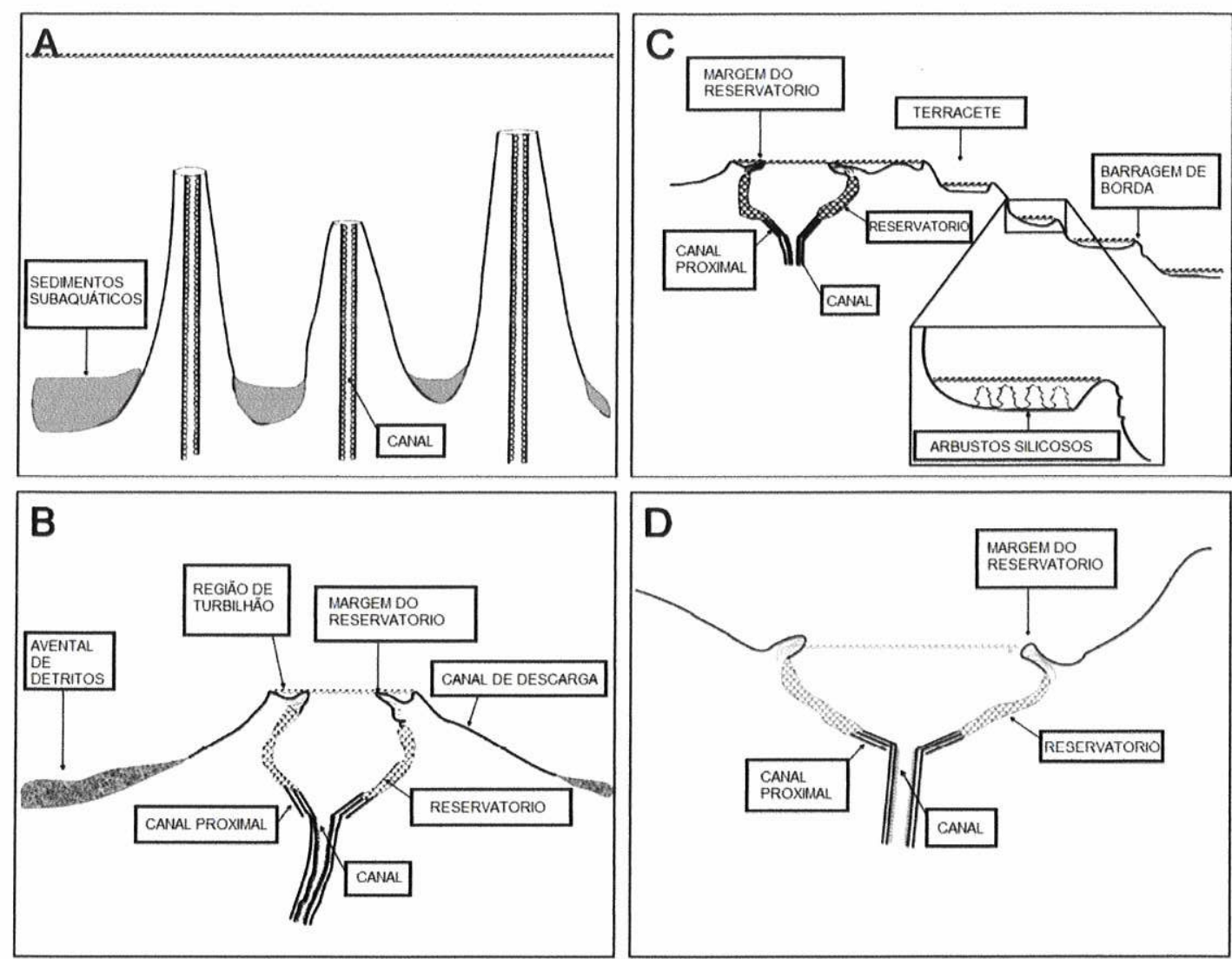

Figura 6.1: Morfotipos associados aos diferentes ambientes hidrotermais do Parque Nacional Yellowstone (WY, EUA): formas cônicas que se formam em ambiente subaquático (A); e, em ambientes subaéreos, montes dômicos (B), montes com terraços (C) e estruturas de baixo relevo associadas a lagoas (D). Modificada de Guidry e Chafetz (2003).

No entanto, observa-se que os "cones" em Anhembi não apresentam a estrutura tão estreita e relevo tão alto como apresentados por Guidry e Chafetz (2003) (figura 6.1). A grande altura das estruturas sugere uma dependência de um ou dois fatores: a duração do hidrotermalismo e a profundidade do corpo de água. Em Yellowstone, os cones chegam a 15 $\mathrm{m}$ de altura e as águas da região são muito mais profundas do que é inferido para o ambiente deposicional da Formação Teresina. O hidrotermalismo em Yellowstone dura, continuamente, milhões de anos, pois o parque está situado sobre um imenso hot spot regional. Em Anhembi, por outro lado, o evento não foi tão duradouro, embora a presença de um segundo outro nível de cones menores, mais abaixo (Yamamoto et al., 2005), implica em pelo menos dois episódios de atividade hidrotermal, separados pelo tempo necessário para a criação de espaço para acomodar os sedimentos entre os dois níveis. A altura das estruturas em Anhembi deve refletir a duração curta do evento e, possivelmente, a pouca profundidade das águas da Bacia do Paraná. Assim, a observação feita em campo de que os topos dos cones mais altos parecem terminar no mesmo plano, se comprovada, poderia significar que estes cones começaram e 
terminaram seu desenvolvimento simultaneamente ou que os cones deixaram de se desenvolver ao se aproximar da superfície da água.

Algo digno de nota nos morfotipos estudados por Guidry e Chafetz (2003) é que entre as estruturas com a mesma anatomia (p. ex., os cones), há uma diferenciação de acordo com sua formação em ambiente subaquático ou subaéreo. Nos formados em ambientes subaquáticos, pouco ou nenhum sedimento acumula nos flancos da estrutura, e o crescimento é principalmente vertical. Já os formados em ambientes subaéreos tendem a estar associados a esse tipo de sedimentação, que resulta em bases mais largas e alturas menores (Guidry e Chafetz, 2003). Neste aspecto, novamente, a interpretação dos cones de Anhembi como depósitos subaquáticos é coerente com análogos modernos.

Cada morfotipo classificado por Guidry e Chafetz (2003) implica em diferentes associações de fácies (esquematizadas na figura 6.1), e, consequentemente, na localização dos lugares mais favoráveis para encontrar fósseis em depósitos hidrotermais antigos. Por exemplo, nos cones em Yellowstone (Guidry e Chafetz, 2003), microfósseis (frústulas de diatomáceas e algumas poucas bactérias) ocorrem nas margens dos reservatórios acima dos canais internos, onde a temperatura, mais baixa, não apresenta mais uma barreira fisiológica ao seu desenvolvimento. Comumente formam microestromatólitos. Guidry e Chafetz (2003) demonstram que a trama estrutural (fabric) do canal interno dos cones presentes em Yellowstone é totalmente abiogênica em decorrência da alta temperatura dentro dos cones, que exclui tanto procariontes como eucariontes. A ausência de fósseis dentro dos próprios cones em Anhembi é coerente com este modelo.

A presença de oncoides é notada por Guidry e Chafetz (2003) em fácies de gêiseres, que são subaéreos, não são subaquáticos. A agitação periódica e flutuações do nível da água associada aos gêiseres são responsáveis pela sua formação. Oncoides usualmente ocupam espaços adjacentes aos gêiseres e são, segundo Guidry e Chafetz (2003), bons indicadores de sua ocorrência e atividade intermitente. Os oncoides descritos por eles exibem grande variação de laminação em seus córtices, sendo que as lâminas mais internas revelam túbulos microbianos e as mais externas são mais escuras, irregulares e descontínuas. Ainda segundo aqueles autores, imagens de microscopia eletrônica de varredura (MEV) mostram com clareza os filamentos microbianos. A gênese dessas estruturas ocorreria da seguinte forma: periodicamente os depósitos adjacentes ao gêiser seriam inundados por água muito quente, impossibilitando o desenvolvimento de procariontes, resultando assim em laminações abiogênicas. Quando essa atividade diminui, as condições logo tornar-se-iam propícias para o 
desenvolvimento desses procariontes, resultando na produção de laminação rica em filamentos microbianos silicificados.

No nível que se estende lateralmente entre os cones analisados em Anhembi (Nível 2) foram encontrados corpos concentricamente laminados com evidências diretas (filamentos) e indiretas (laminações irregulares) de serem de origem microbiana, ou seja, de serem oncoides. Eles são encontrados em certa abundância nesse nível, ao contrário do que ocorre nos níveis 1 e 3. Seu tamanho é de aproximadamente $1 \mathrm{~cm}$ de diâmetro, em rudstones oncolíticas, muito embora na maioria dos casos os filamentos são mal preservados ou ausentes. Nas figuras 5.11, 5.12 e 5.13 são observados esses filamentos num caso excepcional de preservação nesse nível. Aliás, em Anhembi, os oncoides estão presentes nos três níveis estudados, mas também ocorrem em muitas outras localidades dentro da Formação Teresina (Neves et al., 2011; Badaró, 2013). Diante deste fato, é possível que os oncoides tenham se formado independentemente das condições hidrotermais, que deve ser verdadeiro para a maioria das ocorrências fora da região de influência hidrotermal de Anhembi e eventualmente para os exemplares dos Níveis 1 e 3 também. Deste modo, sua presença em Nível 1 em Anhembi seria meramente uma coincidência. $\mathrm{Ou}$, pode ser que o hidrotermalismo tenha exercido uma influência indireta, tornando o local inóspito para a maioria dos organismos, mas não para os micróbios formadores e habitantes de oncoides.

Os fósseis encontrados na região de Anhembi demonstram diferenciação entre os níveis analisados. No Intervalo A, abaixo da base dos cones, existem conchas de moluscos bivalves, uma bone-bed que contém fragmento de dente de peixe dipnoico juntamente com outras escamas e dentes fragmentados, além de ostracodes em relativa abundância, oncoides, e algas carófitas, essas identificadas por Ragonha e Soares (1974). Este conjunto de fósseis sugere que a região em si ou suas proximidades já foram habitadas por uma comunidade biológica complexa naquele intervalo. A presença dos peixes dipnoicos, das algas carófitas e a possível presença de ostracodes dos gêneros Darwinula ou Gutschikia indicam uma influência continental dentro da sedimentação desse ambiente e também de águas relativamente calmas para essa região, já que as carófitas não suportam alta turbidez da água (Ragonha e Soares, 1974). A coquina em que estão presentes os bivalves no Intervalo A (figura 5.2), assim, deve representar um tempestito, evidenciando breves momentos de alta energia naquele ambiente em que as conchas mais fragmentadas foram agrupadas com as conchas inteiras, e estas foram desarticuladas e transportadas, mas não muito longe de seu local de habitação. 
No Intervalo B (Nível 2), existem oncoides em relativa abundância e com filamentos preservados, juntamente com ostracodes, esses mais raros e com as valvas sempre desarticuladas, exceto em poucos casos (figura 5.16). As rochas encontradas aqui, assim como na parte superior do Nível 1 (onde elas encontram-se muito próximas da ocorrência dos cones) apresentam evidente alteração (tabela 6.1) de estruturas sedimentares e de componentes das rochas (p. ex. ooides), muito possivelmente em função da silicificação intensa provocada pelo evento hidrotermal (Jones e Renaut, 1997).

No Intervalo $\mathrm{C}$, foi possível observar mais conchas de bivalves e maior abundância de ostracodes, inclusive alguns ainda articulados, juntamente com oncoides, mas esses apresentavam poucos sinais de filamentos em seu interior (tabela 6.2). As rochas desse intervalo apresentam litotipos variados, com os fósseis ocorrendo em grainstones e rudstones com silicificação pervasiva mas com muito menos substituição do que nos níveis 1 e 2 . Esta observação é coerente com a interpretação de que essas rochas teriam se depositado após o evento hidrotermal. 
Tabela 6.1: Detalhes da diferença da silicificação presente nos níveis 1 e 2 quando comparada com o Nível 3.

\begin{tabular}{|c|c|c|}
\hline Característica & Níveis 1 e 2 & Nível 3 \\
\hline $\begin{array}{l}\text { Mineralogia original } \\
\text { (carbonato) }\end{array}$ & $\begin{array}{l}\text { Praticamente totalmente } \\
\text { substituída, sobrando apenas } \\
\text { minerais opacos (pirita), como } \\
\text { "sujeira" generalizada ou } \\
\text { demarcando formas e contornos } \\
\text { dos componentes originais. }\end{array}$ & $\begin{array}{l}\text { Maior parte da rocha } \\
\text { continua carbonato. }\end{array}$ \\
\hline $\begin{array}{l}\text { Componentes } \\
\text { originais }\end{array}$ & Mal preservados a apagados & Bem definidos \\
\hline $\begin{array}{l}\text { Natureza da } \\
\text { substituição }\end{array}$ & $\begin{array}{l}\text { Intensa, às vezes aparentando } \\
\text { superposição de efeitos, como } \\
\text { sugerido por áreas ("nuvens”) } \\
\text { entrecortantes de qualidades } \\
\text { distintas de preservação. }\end{array}$ & $\begin{array}{l}\text { Substituição parcial de } \\
\text { estruturas, englobando } \\
\text { conjuntos de cristais e } \\
\text { manchas do carbonato de } \\
\text { tamanhos variados. }\end{array}$ \\
\hline Sílica de substituição & $\begin{array}{l}\text { Microquartzo com textura } \\
\text { microssacaroide }\end{array}$ & $\begin{array}{l}\text { Microquartzo, quase } \\
\text { criptocristalino com } \\
\text { textura microssacaroide }\end{array}$ \\
\hline $\begin{array}{l}\text { Sílica de } \\
\text { preenchimento de } \\
\text { poros }\end{array}$ & $\begin{array}{l}\text { Calcedônia fibrorradiada } \\
\text { substitui revestimento isópaco } \\
\text { prévio (sílica opalina?) e } \\
\text { preenche espaço restante }\end{array}$ & $\begin{array}{l}\text { Calcedônia fibrorradiada } \\
\text { preenche poros sem } \\
\text { substituir cimento } \\
\text { original (calcita blocosa). }\end{array}$ \\
\hline $\begin{array}{l}\text { Outras feições } \\
\text { distintas (evidência de } \\
\text { hidrotermalismo?) }\end{array}$ & $\begin{array}{l}\text { 1) Revestimento parcial de poros } \\
\text { por sílica isópaca (opalina?) } \\
\text { 2) Feições tubulares cortando } \\
\text { estrutura original e sílica de } \\
\text { substituicão }\end{array}$ & $\begin{array}{l}\text { Não apresenta nenhuma } \\
\text { dessas duas feições }\end{array}$ \\
\hline
\end{tabular}

Tabela 6.2: Conteúdo fóssil dos intervalos A, B e C.

\begin{tabular}{llll}
\multicolumn{4}{l}{ Tabela 6.2: Conteúdo fóssil dos intervalos A, B e C. } \\
\hline Fósseis & Intervalo A & Intervalo B & Intervalo C \\
\hline Bivalves & $\mathrm{X}$ & -- & $\mathrm{X}$ \\
Ostracodes & $\mathrm{X}$ & $\mathrm{X}$ & $\mathrm{X}$ \\
Oncoides & $\mathrm{X}$ & $\mathrm{X}$ & $\mathrm{X}$ \\
Escamas e dentes de peixes & $\mathrm{X}$ & $?$ & $\mathrm{X}$ \\
paleonisciformes & $\mathrm{X}$ & -- & - \\
Dente de peixe dipnoico & $\mathrm{X}$ & -- & -- \\
Oogônios de carófitas & & & \\
\hline
\end{tabular}

A natureza dos filamentos microbianos analisados, aparentemente remete a cianobactérias, devido ao desenho regular de suas paredes, seu hábitos de crescimento, 
diâmetro muito pequeno e associação a oncoides. Como estão ausentes estruturas celulares visíveis, a parte preservada seria sua bainha mucilaginosa externa. Contudo, a preservação não permite o diagnóstico taxonômico preciso, principalmente porque a parte celular dos filamentos (os tricomas) não se conservou e a o intenso processo de silicificação (substituição) foi muito ocultou muitos detalhes desses organismos (Jones e Renaut, 1997; McKenzie et al., 2001).

Os filamentos microbianos presentes em oncoides são comumente encontrados em regiões hidrotermais de ambientes modernos em Chile, Estados Unidos e Nova Zelândia (Jones e Renaut,1997, Jones et al., 1999, McKenzie et al. 2001, Guidry e Chafetz, 2003, Lowe e Braunstein, 2003, Lynne et al., 2008, Pirajno, 2009, McCall, 2010). O que se nota nesses trabalhos é que alguns oncoides apresentam estruturas complexas em sua superfície, como microestromatólitos.

Muitos autores identificaram outros tipos de microbialitos (estromatólitos e esteiras microbianas), além de oncoides, em regiões influenciadas pelo hidrotermalismo. Os trabalhos de Walter et al. (1972), Yun (1986), Schultze-Lam et al. (1995), Jones e Renaut (1997), Jones et al. (1999), Jones et al. (2001), Jones e Renaut (2003), Lowe e Braunstein (2003), Canet et al. (2005), Lynne et al. (2008), Martin et al. (2008), Pirajno (2009), Cangemi et al. (2010), McCall (2010), Berelson et al. (2011) identificaram tais microbialitos e comunidades microbianas em diferentes localidades com relativa abundância. Em Anhembi, não foram identificados estromatólitos próximos dos cones silicosos, embora esses trabalhos sejam sugestivos de sua ocorrência.

Microfósseis de procariontes associados a estromatólitos e, em menor grau, a oncoides são frequentes no registro geológico, sobretudo no Proterozoico. A ocorrência de microfósseis mais antigos, do Arqueano, por exemplo, sempre foi controversa, mas Schopf (1993) descreveu 11 táxons de procariontes filamentosos de aproximadamente 3,465 Ga no Apex Chert, do Supergrupo Pilbara no noroeste da Austrália Ocidental, sugerindo que a biota do Eoarqueano teria sido mais diversa do que se considerava anteriormente. $\mathrm{O}$ ambiente de deposição foi interpretado como praial influenciado por ondas, sendo que os microfósseis teriam sido encontrados em grãos de silexito arredondados transportados por longa distância e redepositados numa rudstone.

Para subsidiar sua interpretação, Schopf (1993) enunciou cinco critérios para diferenciar microfósseis de objetos abiogênicos em rochas muito antigas, no caso, arqueanas: 1 Os microfósseis devem ocorrer dentro da rocha analisada;

2 A rocha com os microfósseis deve ser de idade comprovadamente arqueana; 
3 Os microfósseis devem ter a mesma idade da rocha arqueana analisada;

4 Os microfósseis devem ser singenéticos com a rocha analisada, ou seja, eles devem ocorrer em rochas formadas em ambientes onde se poderia esperar a presença de microrganismos;

5 Os microfósseis devem ter origem biológica assegurada.

Os depósitos analisados por Schopf (1993) se tratam de um silexito fossilífero primário e não de origem secundária ou intrusiva. Para o autor, todos os filamentos identificados satisfazem os critérios delimitados para identificar microfósseis arqueanos. No entanto, como lembrado pelo autor, os filamentos são pobremente preservados, difícultando a identificação de suas afinidades taxonômicas.

Brasier et al. (2002) questionaram as evidências que comprovariam a biogenicidade dos filamentos identificados por Schopf (1993), com base no reestudo da região de coleta e dos microfósseis em si. Chamaram atenção às seguintes observações: os depósitos da região seriam brechas em veios de sílex de origem hidrotermal, contrariando a interpretação praial anterior, e os grãos arredondados contendo os filamentos seriam, na verdade, cimentos isópacos internos, não clastos provenientes de um depósito mais antigo. Os autores, porém, mantêm uma origem hidrotermal para o veio de sílex e para o sílex estratiforme na região, como originalmente interpretado. Adicionalmente, Brasier et al. (2002) questionam a biogenicidade dos próprios filamentos microbianos, afirmando que eles se tratam de artefatos secundários, ou seja, pseudofósseis, formados por grafita amorfa.

As evidências provenientes da espectrometria de laser Raman apresentadas por Schopf et al. (2002) que confirmariam a composição carbonácea dos filamentos, comprovando, portanto, sua origem biológica também são rebatidas por Brasier et al. (2002), para quem os dados Raman não são suficientes para comprovar que os filamentos são de fato fósseis. Esta controvérsia complexa se estende até hoje, sem um consenso sobre a biogenicidade dessas estruturas (Schopf, 2006; Brasier et al., 2006).

A respeito do debate Schopf - Brasier, a presença de filamentos microbianos e oncoides em silexitos associados à porção basal dos cones de Anhembi demonstra a possibilidade de preservação de microrganismos em ambientes hidrotermais. É verdade que as diferenças de idade e tipo de preservação entre as duas ocorrências são significantes. Os depósitos estudados por Schopf são mais de dez vezes mais velhos do que os de Anhembi, e seus filamentos consistem de restos carbonosos raros de fragmentos de tricomas celulares, enquanto os filamentos estudados no presente trabalho são moldes compridos e localmente abundantes de bainhas cilíndricas sem vestígios de células ou de matéria orgânica. Mesmo assim, os filamentos de Anhembi mostram que é possível encontrar microfósseis em 
ambientes hidrotermais. No entanto, não se pode ignorar os problemas que Brasier et al. (2002) apontam para a interpretação biológica dessas estruturas. 


\section{CONCLUSÕES}

Os fósseis encontrados no presente trabalho denotam diferenças da composição da biota nos níveis abaixo, lateralmente contínuos e acima da ocorrência dos cones silicosos, entretanto deve-se ressaltar que essa diferença é sutil e preliminar, o que indica que estudos mais detalhados devem ser realizados para poder confirmar as observações elencadas aqui. A interpretação de Schopf (1993), no entanto, não pôde ser corroborada, pois os filamentos microbianos analisados nesse trabalho são morfologicamente diferentes daqueles no Apex Chert, além de apresentarem diferente preservação. Além disso, em Anhembi, o contexto hidrotermal foi diferente daquele presente no Apex Chert. Contudo, deve ser ressaltado que os microfósseis filamentosos estão presentes em ambos os ambientes (supondo que Schopf (1993) esteja correto) e também em análogos modernos. Os questionamentos de Brasier et al. (2002) são relevantes e também devem ser ressaltados.

Este trabalho também contribuiu para evidenciar as diferenças de silicificação entre os níveis 1 e 2 e o Nivel 3, já que os anteriores apresentam silicificação muito mais intensa, evidenciada pela total substituição dos componentes originais da rocha e à aparência "suja" das amostras ao microscópio petrográfico, presença de pirita. 


\section{REFERÊNCIAS BIBLIOGRÁFICAS}

ALMEIDA, C. M.; DO CARMO, D. A. 2005. Taxonomia e paleoecologia de ostracodes do Permiano da Bacia do Paraná, Estado de Goiás, Brasil. In: CONGRESSO BRASILEIRO DE PALEONTOLOGIA, 19, CONGRESSO LATINO-AMERICANO DE PALEONTOLOGIA, 6, Aracaju. Resumos... Aracaju: Sociedade Brasileira de Paleontologia, Resumos (CD).

ALMEIDA, F. F. M. 1980. Tectônica da Bacia do Paraná no Brasil. São Paulo: Relatório PAULIPETRO $\mathrm{n}^{\circ} 14.091,187 \mathrm{p}$.

ARAÚJO, C. C. 2003. Gênese da ocorrência de arenito asfáltico da borda leste da Bacia do Paraná, SP. São Paulo, Instituto de Geociências, Universidade de São Paulo, Tese de Doutoramento, $135 \mathrm{p}$.

BADARÓ, V. C. S. Paleobiologia e contexto deposicional de microbialitos silicificados da Formação Teresina (Permiano, Bacia do Paraná) no centro do Estado de São Paulo. 2013. São Paulo, Instituto de Geociências, Universidade de São Paulo, Dissertação de Mestrado, 92 p.

BERELSON, W. W.; CORSETTI, F. A.; PEPE-RANNEY, C.; HAMMOND, D. E.; BEAUMONT, W.; SPEAR, J. R. 2011. Hot spring siliceous stromatolites from Yellowstone National Park: assessing growth rate and laminae formation. Geobiology, v. 9, p. 411-424.

BOURDREAU, A. E.; LYNNE, B. Y. 2012. The growth of siliceous sinter deposits around high-temperature eruptive hot springs. Journal of Volcanology and Geothermal Research, v. 247-248, p. 1-8.

BRASIER, M. D.; GREEN, O. R.; JEPHCOAT, A. P.; KLEPPE, A. K.; VAN KRANENDONK, M. J.; LINDSAY, J. F.; STEELE, A.; GRASSINEAU, N. V. 2002. Questioning the evidence for Earth's oldest fossils. Nature, v. 416, p. 76-81.

BRASIER, M.; McLOUGHLIN, N.; GREEN, O.; WACEY, D. 2006. A fresh look at the fossil evidence for early Archaean cellular life. Philosophical Transactions of the Royal Society B, n. 361, p. 887-902.

CANET, C.; PROL-LEDESMA, R. M.; TORRES-ALVARADO, I.; GILG, H. A; VILLANUEVA, R. E.; LOZANO-SANTA CRUZ, R. 2005. Silica-carbonate stromatolites related to coastal hydrothermal venting in Bahía Concepción, Baja California Sur, Mexico. Sedimentary Geology, v. 174, p. 97-113.

CANGEMI, M.; BELLANCA, A.; BORIN, S.; HOPKINSON, L.; MAPELLI, F.; NERI, R. 2010. The genesis of actively growing siliceous stromatolites: Evidence from Lake Specchio di Venere, Pantelleria Island, Italy. Chemical Geology, v. 276, p. 318-330.

CAVALLARO, F. A. 2013. Investigação Geofisica do Alto Estrutural de Anhembi - SP. São Paulo, Instituto de Geociências, Universidade de São Paulo, Tese de Doutoramento, 148 p.

DAEMON, R. F.; QUADROS, L. P. 1970. Bioestratigrafia do Neopaleozóico da Bacia do Paraná. In: CONGRESSO BRASILEIRO DE GEOLOGIA, 24, 1970, Brasília. Anais... Brasília: Sociedade Brasileira de Geologia, p. 359-412. 
DUNHAM, R. J. 1962. Classification of carbonate rocks according to depositional texture. In: HAM, W. E. Classification of carbonate rocks. American Association of Petroleum Geologists, p. 108-121.

EMBRY, A. F.; KLOVAN, J. E. 1971. A late Devonian reef tract on northeastern Banks Island, Northwest Territories. Bulletin of Canadian Petroleum Geology, v. 33, p. 730-781.

FLÜGEL, E. 2004. Microfacies of Carbonate Rocks: Analysis, Interpretation and Application. Amsterdam: Springer, 976 p.

GRADSTEIN, F.; OGG, J.; SCHMITZ, M.; OGG, G. 2012. The Geologic Time Scale-2012. Amsterdam: Elsevier, $1176 \mathrm{p}$.

GUIDRY, S.A.; CHAFETZ, H. S. 2003. Anatomy of siliceous hot springs: examples from Yellowstone National Park, Wyoming, USA. Sedimentary Geology, v. 157, p. 71-106.

HOLZ, M., FRANÇA, A. B.; SOUZA, P. A., IANUZZI, R.; ROHN, R. 2010. A stratigraphic chart of the Late Carboniferous / Permian sucession of the eastern border of the Paraná Basin, Brazil, South America. Journal of South American Earth Sciences, v. 29, p. 381-399.

JONES, B.; RENAUT, R. W. 1997. Formation of sílica oncoids around geysers and hot springs at El Tatio, northern Chile. Sedimentology, v. 44, p. 287-304.

JONES, B.; RENAUT, R. W. 2003. Hot spring and geyser sinters: the integrated product of precipitation, replacement and deposition. Canadian Journal of Earth Sciences, v. 40, p. 1549-1569.

JONES, B.; RENAUT, R. W.; ROSEN, M. R. 1999. Actively growing siliceous oncoids in the Waiotapu geothermal area, North Island, New Zealand. Journal of the Geological Society, v. 156, p. $89-103$.

JONES, B.; RENAUT, R. W.; ROSEN, M. R. 2001. Microbial construction of siliceous stalactites at geysers and hot springs: Examples from the Whakarewarewa geothermal area, North Island, New Zealand. Palaios, v. 16, p. 73-94.

LOWE, D. R.; BRAUNSTEIN, D. 2003. Microstructure of high-temperature $\left(>73^{\circ} \mathrm{C}\right)$ siliceous sinter deposited around hot springs and geysers, Yellowstone National Park: The role of biological and abiological processes in sedimentation. Canadian Journal of Earth Sciences, v. 40, p. 1611-1642.

LYNNE, B. Y.; CAMPBELL, K. A.; MOORE, J.; BROWNE, P. R. L. 2008. Origin and evolution of the Steamboat Springs siliceous sinter deposit, Nevada, USA. Sedimentary Geology, v. 210, p. 111-131.

MARANHÃO, M. S. A. S.; PETRI, S. 1997. Novas ocorrências de fósseis nas Formações Corumbataí e Estrada Nova do Estado de São Paulo e considerações preliminares sobre seus significados paleontológico e bioestratigráfico. Revista do Instituto Geológico, v. 17, n.1, p. 33-54.

MARTIN, W.; BAROSS, J.; KELLEY, D.; RUSSELL, M. J. 2008. Hydrothermal vents and the origin of life. Nature Reviews, v. 6, p. 1-10. 
McCALL, J. 2010. Lake Bogoria, Kenya: Hot and warm springs, geysers and Holocene stromatolites. Earth-Science Reviews, v. 103, p. 71-79.

McKENZIE, E. J.; BROWN, K. L.; CADY, S. L.; CAMPBELL, K. A. 2001. Trace metal chemistry and silicification of microorganisms in geothermal sinter, Taupo Volcanic Zone, New Zealand. Geothermics, v. 30, p. 483-502.

MEGLHIORATTI, T. 2006. Estratigrafia de sequências das formações Serra Alta, Teresina e Rio do Rasto (Permiano, Bacia do Paraná) na porção nordeste do Paraná e centro-sul de São Paulo. Rio Claro, Instituto de Geociências e Ciências Exatas, Universidade Estadual Paulista, Dissertação de Mestrado, 169 p.

MILANI, E. J. 1997. Evolução tectono-estratigráfica da Bacia do Paraná e seu relacionamento com a geodinâmica fanerozoica do Gondwana sul-ocidental. Porto Alegre, Instituto de Geociências, Universidade Federal do Rio Grande do Sul, Tese de Doutoramento, 2 v., 255 p.

MILANI, E. J.; FRANÇA, A. B.; SCHNEIDER, R. L. 1994. Bacia do Paraná. Rio de Janeiro: Boletim de Geociências da PETROBRÁS, v. 8, n. 1, p. 69-82.

MILROY, P. G.; WRIGHT, V. P. 2002. Fabrics, facies control and diagenesis of lacustrine ooids and associated grains from the Upper Triassic, southwest England. Geological Journal, v. 37 , p. $35-53$.

NEREGATO, R.; SOUZA, P. A.; ROHN, R. 2008. Registros palinológicos inéditos nas formações Teresina e Rio do Rasto (Permiano, Grupo Passa Dois, Bacia do Paraná): Implicações biocronoestratigráficas e paleoambientais. Revista Pesquisa em Geociências, v. 35 , n. 2, p. 9-21.

NEVES, J. P.; ROHN, R.; SIMÕES, M. G. 2011. Tafonomia de tempestitos conchíferos amalgamados da Formação Teresina em Rio Preto (Estado do Paraná, Permiano Médio, Bacia do Paraná) e suas implicações paleoambientais. Revista do Instituto de Geociências-USP, v. 11, n. 3, p. 131-147.

PEREIRA, E.; CARNEIRO, C. D. R.; BERGAMASCHI, S.; ALMEIDA, F. F. M. 2012. Evolução das Sinéclises Paleozoicas: Províncias Solimões, Amazonas, Parnaíba e Paraná. In: HASUI, Y.; CARNEIRO, C. D. R.; ALMEIDA, F. F. M.; BARTORELLI, A. (Orgs.) Geologia do Brasil. São Paulo: Beca, p. 374-394.

PIRAJNO, F. 2009. Hydrothermal Processes and Mineral Systems. Berlin: Springer, 1246 p.

ROHN, R. 1994. Evolução ambiental da Bacia do Paraná durante o Neopermiano no leste de Santa Catarina e do Paraná. São Paulo, Instituto de Geociências, Universidade de São Paulo, Tese de Doutoramento, 2 v., 327 p.

ROHN, R. 2001. A estratigrafia da Formação Teresina (Permiano, Bacia do Paraná) de acordo com furos de sondagem entre Anhembi (SP) e Ortigueira (PR). Correlação de Sequências Paleozoicas Sul-americanas, n. 20, 209-218. 
ROHN, R.; STOLLHOFEN, H. 2000. The Permian age of the Passa Dois Group (Paraná Basin, Southern Brazil). In: INTERNATIONAL GEOLOGIC CONGRESS, 31, 2000, Rio de Janeiro. Resumos... Rio de Janeiro: Sociedade Brasileira de Geologia.

SANTOS, R. V.; SOUZA, P. A.; ALVARENGA, C. J. S.; DANTAS, E. L.; PIMENTEL, M. M.; OLIVEIRA, C. G.; ARAÚJO, L. M. 2006. Shrimp U-Pb zircon dating and palinology of betonitic layers of the Permian Irati Formation, Paraná Basin, Brazil. Gondwana Research, v. 9, p. 456-463.

SCHNEIDER, R. L.; MÜHLMANN, H.; TOMMASI, E.; MEDEIROS, R. A.; DAEMON, R. F.; NOGUEIRA, A. A. 1974. Revisão estratigráfica da Bacia do Paraná. In: CONGRESSO BRASILEIRO DE GEOLOGIA, 28, 1974, Porto Alegre. Anais... São Paulo: Sociedade Brasileira de Geologia, v. 1, p. 41-65.

SCHOLLE, P. A. 1974. A Color Illustrated Guide to Carbonate Rock Constituents, Textures, Cements, and Porosities. Tulsa: Association of Petroleum Geologists, 241 p.

SCHOPF, J. W. 2006. Fossil evidence of Archaean life. Philosophical Transactions of the Royal Society B, n. 361, p. 869-885.

SCHOPF, W. J. 1993. Microfossils of the Early Archean Apex Chert: New evidence of the antiquity of life. Science, v. 260, p. 640-646.

SCHOPF, W. J.; KUDRYAVTSEV, A. B.; AGRESTI, D. G.; WDOWIAK, T. J; CZAJA, A. D. 2002. Laser-Raman imagery of Earth's earliest fossils. Nature, v. 416, p. 73-76.

SCHULTZE-LAM, S.; FERRIS, F. G.; KONHAUSER, K. O.; WIESE, R. G. 1995. In situ silicification of an Icelandic hot spring microbial mat: implications form microfossil formation. Canadian Journal of Earth Sciences, v. 32, p. 2021-2026.

SIMÕES, M. G.; ANELLI, L. E.; DAVID, J. M. 2010. Othonella araguaiana (Bivalvia, Megadesmidae) from the Corumbataí Formation (Middle Permian), eastern margin of the Paraná Basin: Systematic, evolutionary and biostratigraphic significances. Revista do Instituto de Geociências - USP, v. 10, n. 2, p. 45-55.

SOUSA, S. H. M.; SUGUIO, K.; CASTRO, J. C. 1991. Sedimentary facies of the Estrada Nova and Corumbataí Formations (Late Proterozoic of the Paraná Basin) in the State of São Paulo, Brazil. In: INTERNATIONAL GONDWANA SYMPOSIUM, 7, São Paulo. Anais... São Paulo: Universidade de São Paulo, p. 161-172.

SOUZA, P. A. 2006. Late Carboniferous palynostratigraphy of the Itararé Subgroup, northeastern Paraná Basin, Brazil. Review of Palaeobotany and Palynology, v. 138, p. 9-29.

SOUZA, P. A.; MARQUES-TOIGO, M. 2005. Progress on the palynostratigraphy of the Permian strata in Rio Grande do Sul State, Paraná Basin, Brazil. Anais da Academia Brasileira de Ciências, v. 77, n. 2, p. 353-365.

TOLEDO, C. E. V. 2001. Análise paleoictiológica da Formação Corumbataí na região de Rio Claro, Estado de São Paulo. Rio Claro, Universidade Estadual Paulista, Dissertação de Mestrado, $146 \mathrm{p}$. 
VIEIRA, A. J. 1973. Geologia do centro e nordeste do Paraná e centro-sul de São Paulo. In: CONGRESSO BRASILEIRO DE GEOLOGIA, 27, 1973, Aracaju. Anais... Aracaju: Sociedade Brasileira de Geologia, v.3, p. 259-277.

WALTER, M. R. 1976. Stromatolites. Amsterdam: Elsevier, 789 p.

WALTER, M. R.; BAULD, J.; BROCK, T. D. 1972. Siliceous algal and bacterial stromatolites in hot spring and geyser effluents of Yellowstone National Park. Nature, v. 178, p. $402-405$.

WHITE, I. C. 1908. Relatório final da Comissão de Estudos das Minas de Carvão de Pedra do Brasil. Rio de Janeiro: Departamento Nacional de Produção Mineral, 617 p.

YAMAMOTO, J. K.; FAIRCHILD, T. R.; BOGGIANI, P. C.; MONTANHEIRO, T. J.; ARAÚJO, C. C. de; KIYOHARA, P. K.; MATOS, S. L. F. de; SOARES, P. C. 2005. A Record of Permian subaqueous vent activity in southeastern Brazil. Nature, p. 1-3.

YAMAMOTO, J. K.; FAIRCHILD, T. R.; BOGGIANI, P. C.; MONTANHEIRO, T. J.; ARAÚJO, C. C.; KIYOHARA, P. K.; MATOS, S. L. F.; SOARES, P. C. 2007. Cones Silicosos de Anhembi, SP: Campo gigante de geiseritos do Permiano da Bacia do Paraná. SIGEP (no prelo), $11 \mathrm{p}$.

YUN, Z. 1986. Thermophilic microorganisms in the hot springs of Tengchong geothermal area, West Yunnan, China. Geothermics, v. 15, n. 3, p. 347-358.

ZALÁN, P. V.; WOLFF, S.; CONCEIÇÃO, J. C. J.; ASTOLFI, M. A. M; VIEIRA, I. S.; APPI, V. T.; ZANOTTO, A.; MARQUES, A. 1991. Tectonics and sedimentation of the Paraná Basin. In: ULBRICH, H.; ROCHA-CAMPOS, A. C. Gondwana Seven Proceedings. São Paulo: Instituto de Geociências - USP, p. 83-117.

ZALÁN, P. V; WOLFF, S.; CONCEIÇÃO, J. C. J.; MARQUES, A.; ASTOLFI, M. A. M.; VIEIRA, I. S.; APPI, V. T.; ZANOTTO, O. A. 1990. Bacia do Paraná. In: GABAGLIA, G. P. R. \& MILANI, E. J. (Eds.). Origem e Evolução de Bacias Sedimentares, Rio de Janeiro: Petrobrás, p. 135-168. 